\title{
The Modernist Sublime: Parenthood and the Intersubjective Sublime Subject in Faulkner, Forster, Lawrence, and Woolf
}

\author{
Erin K. Johns Speese \\ West Virginia University
}

Follow this and additional works at: https://researchrepository.wvu.edu/etd

\footnotetext{
Recommended Citation

Speese, Erin K. Johns, "The Modernist Sublime: Parenthood and the Intersubjective Sublime Subject in Faulkner, Forster, Lawrence, and Woolf" (2013). Graduate Theses, Dissertations, and Problem Reports. 5003.

https://researchrepository.wvu.edu/etd/5003

This Dissertation is protected by copyright and/or related rights. It has been brought to you by the The Research Repository @ WVU with permission from the rights-holder(s). You are free to use this Dissertation in any way that is permitted by the copyright and related rights legislation that applies to your use. For other uses you must obtain permission from the rights-holder(s) directly, unless additional rights are indicated by a Creative Commons license in the record and/ or on the work itself. This Dissertation has been accepted for inclusion in WVU Graduate Theses, Dissertations, and Problem Reports collection by an authorized administrator of The Research Repository @ WVU. For more information, please contact researchrepository@mail.wvu.edu.
} 
The Modernist Sublime:

Parenthood and the Intersubjective Sublime Subject in Faulkner, Forster, Lawrence, and Woolf

Erin K. Johns Speese

\begin{abstract}
Dissertation submitted to the Eberly College of Arts and Sciences at West Virginia University in partial fulfillment of the requirements for the degree of
\end{abstract}

\title{
Doctor of Philosophy \\ In \\ English Literature
}

\author{
Lisa Weihman, Ph.D., Chair \\ Gwen Bergner, Ph.D. \\ Ryan Claycomb, Ph.D. \\ Adam Komisaruk, Ph.D. \\ Lisa Rado, Ph.D. \\ Department of English
}

\section{Morgantown, West Virginia 2013}

Keywords: Modernism, Sublime, Gender Studies, Parenthood, Intersubjectivity Copyright 2013 Erin K. Johns Speese 


\title{
ABSTRACT \\ The Modernist Sublime: \\ Parenthood and the Intersubjective Sublime Subject in Faulkner, Forster, Lawrence, and Woolf
}

\author{
Erin K. Johns Speese
}

This project explores how the modern novel restructures traditional conceptions of the Romantic sublime through complex depictions of parenthood. Using related strategies of representation, William Faulkner, E.M. Forster, D.H. Lawrence, and Virginia Woolf rewrite the traditional sublime as an intersubjective experience, dependent upon the recognition of social objectification and an ethics of reciprocal sympathy between mothers and fathers. Ultimately, The Modernist Sublime contributes to modernist scholarship by exploring the dynamics of modernist representations of parenthood and by focusing attention on how modernist authors reconsider the function of the sublime in the modern world.

Juxtaposing traditional aesthetics and Slavoj Žižek's concept of the "sublime object of ideology" with recent theoretical work regarding identity, I argue that these modern novelists construct what I term a "sublime subject" (or a person who functions in the space of the traditional sublime object) in order to reveal the possibility of a sublime experience that favors emotional connection over reason. These novelists critique the objectification of the other in favor of a sublime experience that reveals the subject-shattering power of empathy. Drawing on Agamben's concept of "homo sacer," in As I Lay Dying, Faulkner reveals the mother as "mater sacer," a woman who both enacts and receives acts of violence that show the ideological rituals regarding the abject mother. Employing recent queer theoretical work on the heteronormative family, Forster's Howards End reveals the possibility of a queer family only through the interaction of a "sublime subject." Perhaps more than any other author in this study, Lawrence presents marriage and the creation of family as a radical experience that results in mutual intersubjective sublime experiences through the generational pairings in The Rainbow. Finally, Woolf promotes sublime interactions between women as part of a feminist polemic embedded in To the Lighthouse. Tracing a transatlantic pattern, British and American modern novelists explore the possibility of human connection in direct confrontation to the aesthetic practice of objectification in both the traditional sublime and the theoretical discourse surrounding early twentieth century poetics. 


\section{Acknowledgements}

I would like to thank my committee for all of their patience and diligence in helping me develop this project. In particular, I appreciate Gwen Bergner's meticulous attention to my prose and argument construction, Ryan Claycomb's generous and insightful feedback, Adam Komisaruk's guidance in all matters sublime, and Lisa Rado's keen eye for developing my points regarding both modernism and the sublime. I would especially like to thank Lisa Weihman for spending eight years with me on this journey and for never wavering in her dedication to both this project and to me as a scholar. In addition, the generous funding that I have received from West Virginia University and its English Department made the completion of this project possible. In particular, for the fellowship support, I am truly grateful. Finally, I would like to thank my family - especially my parents, my brother, and my partner-for offering unwavering support throughout the many stages of this project and my life. 


\title{
Table of Contents
}

\author{
Chapter One 1 \\ Introduction \\ Chapter Two \\ 47 \\ Mater Sacer: Addie as Sublime Object in William Faulkner's As I Lay Dying \\ Chapter Three $\quad 85$ \\ Only Disconnect: Ruth Wilcox, Death, and the Sublime Object in Howards End \\ Chapter Four $\quad 122$ \\ Ursula's Disempowered Rainbow: \\ Sublime Intersubjective Mother/Father Relationships in D.H. Lawrence's The Rainbow \\ Chapter Five $\quad 157$ \\ "What is R?": Mrs. Ramsay as Feminism's Sublime Object in To the Lighthouse \\ Epilogue \\ 196 \\ Intersubjectivity, Feminism, and the Mother \\ Endnotes $\quad 200$ \\ Works Cited $\quad 224$
}




\section{Chapter One: Introduction}

For three years, out of key with his time, He strove to resuscitate the dead art Of poetry; to maintain "the sublime" In the old sense. Wrong from the start-

No, hardly, but, seeing he had been born In a half savage country, out of date...

-Ezra Pound, Hugh Selwyn Mauberley

It all starts with Ezra Pound. At least, that is how the story of canonical modernism has often been narrated. He is the father of so many early twentieth century literary movements (like Imagism and Vorticism) as well as the modernist aesthetic dictum: "Make it new." So, what is Pound's place in a study of canonical modernist novelists? In terms of direct influence, not much. In terms of modernist aesthetics, everything. I begin with an epigraph from Pound's Hugh Selwyn Mauberley, because it examines the relationship between a modernist writer and traditional aesthetics. Despite his attempts at defying his poetic predecessors, Pound reifies the poet as "genius" and maintains the need for aesthetic objects in order to explore the poet as subject. Of all the aesthetic concepts he could have cited in the beginning of Hugh Selwyn Mauberley, Pound chooses to invoke "the sublime," the one aspect of Kantian and Burkean aesthetics that is concerned with the construction of subjectivity rather than the object of the artist's gaze. Unlike its counterpart, beauty, the sublime represents a very specific, masculine tradition and discourse associated with reason. Pound's choice to begin with the sublime situates the poem as not only a treatise on traditional aesthetics but also its gendered constructions.

Pound begins Hugh Selwyn Mauberley with a discussion of the artist's failed attempts to resuscitate traditional, Romantic notions of poetry that are "out of key with his time" (ln 1). Pound's use of "'the sublime'/ In the old sense" (ln 3-4) links sublimity to its masculine tradition while also suggesting that "the old sense" of the sublime is no longer valid for modernist 
aesthetics. Pound's enjambment of the line "Wrong from the start" (ln 4) at the end of the first stanza suggests that there is a new form of sublimity that is not "wrong," but related to issues of identity like nationality and birth in the second stanza. Pound juxtaposes aesthetics with subjectivity through identity and history by describing Hugh as born "out of date," showing a modernist sense of distance and displacement. Like the style of the poem, the modernist subject exists as an enjambment between late nineteenth-century and twentieth-century ideological structures. The subject/object approach of traditional aesthetics and the sublime no longer represents modernist subjectivity. Pound's declaration in Hugh Selwyn Mauberley carries out a number of associations between aesthetics and subjectivity formulated in terms of patriarchal inheritance and/or family structure related to issues of "birth" and nationality that appear from 1910 to the 1930s. Like William Faulkner, E.M. Forster, D.H. Lawrence, and Virginia Woolf, Pound questions the adequacy of eighteenth-century aesthetics and nineteenth-century ideological structures by connecting birth, sublimity, and subjectivity. The key to understanding this modernist response to sublimity is through an examination of the object (an aesthetic item), objectivity (the artist's "unbiased" representation), and objectification (the substitution of objects for people).

Unlike the poetry of modernism, the modernist novel returns to images of the Victorian and newly emerging early twentieth-century family. The personal is of utmost importance in the construction of modern identity, and as a result of Sigmund Freud's emphasis on the family, personal identity is related through interaction and conflict in the family. Faulkner, Forster, Lawrence, and Woolf point to gender and its performance as key to not only familial but social conflict. These novelists suggest that the family consistently fails to align with its ideological image. Using new, experimental prose forms like stream-of-consciousness, modernist novelists 
explore the possibility of human connection by rewriting the imagined "objectivity" of aesthetics. Using the inherent tensions between objectivity and subjectivity in the sublime, these writers stress the importance of subjectivity against multiple social discourses that claim to be "objective." Although these writers explore issues of sexuality, race, and class, familial gender dynamics become the main focus for an emotional rewriting of aesthetics and intersubjectivity. Sexuality, race, and class all come into play in many of these novels, but gender difference overtly shows larger social conflicts about identity in these novels. These writers reconsider sublimity through gender inequalities consistently depicted in ideal images of the Victorian family.

Ultimately, I combine the ideological "sublime object" of Slavoj Žižek, the symbolic object (patriarch) and subject approach to gothic fiction of Anne K. Mellor, the queerly sublime practice of Lee Edelman, and the ethical solution of Joanna Zylinska in order to reconfigure the sublime experience between two empathic subjects, the Victorian mother/wife and father/husband, in modernist novels. Instead of the "sublime object" of Žižek, I propose the "sublime subject" - a person (rather than a thing) that can create a sublime experience. Like the gothic "patriarch" of Mellor, I examine the Victorian "patriarch," replete with an understanding of masculinity that is as constructed as femininity. Drawing on the sinthomosexual, a "sublime subject," who offers rupture as the realization of identity as ideological nothingness, I explore the possibility of a reciprocal relationship where the queer figure fulfills the role of both object and subject. Using Zylinska's self/other representation of an ethical sublime that elides difference through the performance of identity, I develop a reciprocal, empathic, and intersubjective sublime in the interactions between two subjects. The combination of these theories provides a rereading of the representation of the sublime by Lawrence, Forster, Faulkner, and Woolf in such 
a way that not only is the sublime, but gender, rewritten to show the collapse and confrontation of binary thinking at the turn-of-the-twentieth-century.

In terms of aesthetic practice, Hugh Selwyn Mauberley employs emotional distance by using an "object" to represent emotions and subjectivity. T.S. Eliot termed this practice the "objective correlative" or "The only way of expressing emotion in the form of art is by finding an 'objective correlative'; in other words, a set of objects, a situation, a chain of events which shall be the formula of that particular emotion; such that when the external facts, which must terminate in sensory experience, are given, the emotion is immediately evoked" (Eliot 948). In the case of William Shakespeare, Eliot argues that Hamlet is unable to project his emotions for his mother onto an "object," and as a result, the "objective correlative" fails because "Hamlet (the man) is dominated by an emotion which is inexpressible, because it is in excess of the facts as they appear" (Eliot 948). Hamlet goes mad because he is unable to objectify his emotions for his mother. As Hugh Selwyn Mauberley continues, Hugh treats World War I as an "object" or series of events representing emotional trauma. Like Hamlet, the World War I soldier becomes mad by not objectifying his wartime trauma. Emotion is the crux of the problem for the modernist subject: how to feel it, how to objectify it, and how to use it to create the possibility for fruitful intersubjective relationships. Eliot's "objective correlative" is just one example of how the discourses circulating during the early twentieth century related emotion and reason to both subjectivity and objectivity. With the rise of Freudian psychoanalysis, emotion begins to play a pivotal role in the discussions of subjectivity which strongly diverge from Enlightenment discourses that focused on reason. The trajectory of modernist poetic aesthetics and the tradition of the modernist novel diverge when it comes to the subject and his/her representation. Unlike Pound and Eliot's brands of aesthetic modernism, the modernist novelist focuses on the subject 
rather than the aesthetic object, offering a different aesthetic from that associated with canonical poetic modernism. ${ }^{1}$ The novelists employ emotion and empathy as a way of combating discourses that tend to marginalize feeling or try to rationalize feeling with logical thought. Inherent in the sublime is emotion and feeling, but Kant and Burke's emphasis on reason ultimately overwhelms the discourse about this underlying component of the sublime.

Through the use of either free indirect discourse or stream-of-consciousness technique, the aesthetic of the modernist novel confronts the possibility of subjectivity and what I call a subject/subject (rather than subject/object) dynamic. The revolutionary aspect of modernist poetry is often associated with stylistic and formal experimentation. With their interest in gender, the canon, and formal aesthetics in the novel, Woolf and Lawrence explicitly explore the problems of parenthood related to the gender norms of the Victorians - a term that I employ as a reference to the most rigid and idealized gender norms that construct a particular image of the mother and father as a result of the separate spheres doctrine. More importantly, they link gender politics to aesthetic practice as a way of challenging literary history and the discourse of aesthetics through the modern novel. Like Pound and Eliot, D.H. Lawrence and Virginia Woolf wrote extensive literary criticism on the canon, aesthetic practice, and the development of modernist style. Unlike Pound and Eliot, Lawrence and Woolf discussed the technical aspects of literature in terms of identity politics that include issues of gender, sexuality, and class. Like the poets, these novelists found a way to challenge the traditional form of the novel while also thinking through the problem of the subject directly in depictions of relationships. This approach allowed Lawrence to articulate an aesthetic of sexuality related to the "solar plexus" and the "bowels," a strong, emotional reaction to sexual desire between subjects. ${ }^{2}$ Woolf's aesthetic practice included a female tradition that thought "back through our mothers if we are women" ( $A$ 
Room of One's Own 75). Through these approaches, aesthetic form links with subjectivity and identity in the modernist novel. The representation of human relationships in these modernist novels reflects the influence of Freudian psychoanalysis with its emphasis on subjectivity and the importance of familial relationships in constructing identity. Writers like Lawrence and Woolf express skepticism for Freud's theories of modern identity as they relate to constructions of gender and sexuality. For Lawrence, Freud is too scientific in his approach, leaving no room for the power of emotion as an almost transcendent force, and for Woolf, Freud presents a limited view of the subject that relies on the objectification of the "other" through gender and sexual power dynamics.

Lawrence and Woolf's approach to the "problem of the subject" invokes the sublime related to the Victorian family. ${ }^{3}$ Both authors challenge the subject/object dynamic of the sublime, but each author offers a radically different perspective on the possibility for change. In To the Lighthouse, Woolf explores the idealized Victorian parent and Freudian Oedipus constructions of parent/child interactions in order to affirm a feminist perspective; she explores the empowering potential of intersubjectivity between women. Woolf figures the problem of subjectivity through artist Lily Briscoe's gaze; Lily spends much of the novel with her gaze focused on Mrs. Ramsay, the Victorian mother. At first, Woolf reinforces the traditional notion of woman as object of the artist's gaze, but she also subverts that tradition by making the artistwho-gazes a woman. Eventually, Lily challenges the determining power of the gaze by questioning her own subjectivity as constructed in relation to a surrogate mother figure, Mrs. Ramsay. Lily relates her identity to her desired relationship with a mother figure. Lily's epiphany translates into abstract paintings that evoke an emotional rather than objective response to the subject. Unlike Woolf, Lawrence's The Rainbow examines familial relationships through 
the husband and wife. Using the standards of Victorian society as a boundary, Lawrence represents the possibility of intersubjectivity across rather than along gender lines. Lawrence portrays multiple, heteronormative relationships by following the Brangwens through many generations. He juxtaposes early nineteenth century and mid-nineteenth century Victorian gender roles by presenting two vastly different married couples: Lydia and Tom and Anna and Will. Lydia and Tom offer a freer approach to gender that is not available to Anna and Will as gendered family roles become more confining in the mid-nineteenth century. Lawrence combats restrictive later Victorian gender roles by representing Lydia and Tom's empathetic relationship as more transcendent than that of Anna and Will. Ultimately, he reveals the social construction of gender for both men and women.

What Lawrence and Woolf have in common is a reconfiguration of the sublime in order to express experiences beyond language and reason. Rather than relying on an "object" to evoke emotion as in Eliot's "objective correlative," they show the importance of connection through development of character. Lawrence and Woolf replace the "object" of the artist's or subject's gaze with another person, "a subject." In a sense, Lydia Brangwen and Mrs. Ramsay function as traditional "objects" of the subject's gaze, but instead of reifying the subject/object dynamic that produces sublimity for the subject, Lawrence and Woolf represent an intersubjective sublimity, in which the other's subjectivity triggers a sublime experience for the viewing subject. The sublime moment is no longer about the self but about empathizing with another. Rather than focusing on the self, the modernist sublime for the novelist is about identifying with the other in order to explore how ideologically constructed identities limit the feelings and desires of a subject. 
While they reveal particularly gendered experiences of intersubjective sublimity, Lawrence and Woolf are part of a larger trajectory of authors that employ the sublime in relationship to parenthood as a way of challenging the Victorian imaginary. Modernist authors E.M. Forster, D.H. Lawrence, William Faulkner, and Virginia Woolf all suggest that birth is an experience that gives parents access to the sublime. Their emphasis on marriage, parenthood, and birth marks a modernist trend of reinterpreting the sublime experience as between two subjects, a mother and a father, rather than between a subject and an object. In this way, modernist texts depart from traditional British Romantic texts that explore how an aesthetic object evokes a sublime experience. Modernism's recalibration of the sublime as an intersubjective experience indicates the movement's intent to discuss, deconstruct, and rethink subject positions, especially in relation to gender. The Rainbow (1915), Howards End (1910), As I Lay Dying (1930), and To the Lighthouse (1927) represent the relationship between mothers and fathers as reciprocal. The depiction of both the father and mother as confined to particular subject positions results in a reciprocal relationship that draws attention to the confinement of social and gender roles. These modern novelists address the possibility of reciprocal, empathetic, and intersubjective relationships through the aesthetic concept of the sublime.

Aesthetic theory, exemplified by Edmund Burke and Immanuel Kant, proposes that the sublime is a transcendent encounter provoked by a physical object. In the typical sublime moment, a person experiences or perceives an object (usually of art or nature) in a way that provokes a transcendent experience of awe, terror, and pain, but also pleasure. Through empirical categorization of sublime objects, Burke suggests that the sublime is evoked in liminal spaces between borders and beyond boundaries. Immanuel Kant, on the other hand, focuses on the mental process that arises in the person experiencing the sublime. Slavoj Žižek has extended 
this traditional theory of the sublime in arguing that the "sublime object" is a signifier of a larger ideological structure that is transcendent (i.e., money is the signifier of capitalism). For Žižek, particular ideologies take on a transcendent function as they come to stand in for an idealized imaginary constructed through language and discourse. The "sublime object" reveals the mechanisms of ideology that appear to work beyond their material signifiers.

I reconfigure traditional aesthetic theory and Žižek's notion of the ideologically loaded "sublime object" by proposing that a sublime subject can provoke the same transcendent experience. The modernist texts I consider rewrite the sublime experience as between two subjects in order to critique subject positions related to marriage, parenthood, and kinship. These authors emphasize human interactions or subject/subject relationships as replicating the structure of the sublime experience. With the exception of The Rainbow, the modernist texts I examine invoke two quintessential components of the sublime: 1) the inadequacy of language to represent the human experience and 2) the tendency of an other's mortality/impending death to provoke a sublime response for the witness. In the first case, the connection between language and masculine discourse allows these authors to use the sublime to critique issues of subjectivity. These authors' reconfiguration of the sublime undermines paternal authority by exposing fathers as empty signifiers of a transcendent patriarchal signified. In essence, the father figure functions as an ideological sublime subject which gives the mother/wife access to the sublime experience. In particular, the patriarch, who is typically associated with language, reveals to the mother figure the inherent failure of language in conveying emotion and desire; the failure reveals to the mother how the father relies on language as part of the gendered expectations of patriarchy. In the second case, the mother's mortality/death prompts a sublime experience for the father. These authors use a trope of the sublime, death, in order to expose the subject's awareness of an other's 
subjectivity. Through grief, the father addresses absence as key to revealing the marginalization of the mother's desires. By invoking death in relationship to its trope in the sublime, the father comes to recognize his role in the objectification of the mother. I suggest that the representation of marriage and parenthood together in these texts implies that witnessing or giving birth as a spouse gives these characters' access to the sublime. ${ }^{4}$

The core focus of my project is to question not only the subject/object theorization of the sublime but also a similar subject/object theorization in the discourse on subjectivity. The question I want to answer is: What happens when a subject no longer sees the other as an object that causes him/her to only confirm, deny, or questions his/her self? The sublime offers the most obvious platform to discuss these issues, because it traditionally employs a literal object in provoking a subject's perception of his/her own mental (or even ego) capabilities. Traditional narratives of the sublime (especially related to male authors) impress the importance of the ego or self, but I analyze what happens when a subject's sublime experience actually focuses on an other's subjectivity in conjunction with his/her own. This project radically rethinks traditional definitions of both the sublime and subjectivity by proposing that human connection can result in a sublime experience in a subject about another subject rather than only his/her self. Although he points to alterity as a key aspect of the sublime, Žižek's postmodern reinterpretation of the sublime also depends upon the objectifying discourses of both aesthetics and psychoanalysis. Žižek points to the possibility of intersubjectivity in the sublime but refrains from explicitly developing it; however, his emphasis on ideology inherently takes into account subjectivity. The modernist texts I examine openly draw on the interplay of sublimity and ideology and directly posit the possibility of intersubjectivity. In essence, these novelists show the intersubjective possibilities that stem from reading the sublime in the manner of Žižek. For these modernists, 
the sublime experience is that of recognizing the subject status of the other and realizing the limitations that subject's status places onto the wants and the desires of the other. Ultimately, these authors reconfigure the sublime to account for the modern subject who is both aware of his/her own subjectivity but also his/her other's subjectivity. Much of the work that attempts to reconsider the sublime from a gendered standpoint often engages in an essentialist assumption that the sex of the writers is what gives them access to the representation of a gendered sublime. ${ }^{5}$ I confront this assumption by focusing on how both male and female authors depict subject/subject sublime experiences for both men and women, accounting for both gendered subject positions rather than privileging one.

Drawing on the psychoanalytic model, Jessica Benjamin's feminist response to the Freudian psychoanalytic model grounds itself in the concept of "intersubjectivity." Although she is a contemporary scholar, Benjamin identifies the possibility of intersubjectivity in psychoanalysis, which corresponds to the representation of relationships that I note in the modernist novel. Benjamin's work responds to the concept of sexual difference by suggesting a more fluid relationship in human interactions. According to Benjamin, intersubjectivity combats subject/object thinking and proposes a relational pattern that includes the mother (who in psychoanalysis is consistently labeled an object) (29-31). In particular, intersubjectivity suggests that "we have a need for recognition and that we have a capacity to recognize others in return, thus making mutual recognition possible" (30). To that end, she proposes that the two dimensions of experience [drive theory and object relations theory] with the object/other are complementary, though they sometimes stand in an oppositional relationship. By embracing both dimensions, we can fulfill the intention of relational theories: to account both for the pervasive effects of human relationships on psychic 
development and for the equally ubiquitous effects of internal psychic mechanisms and fantasies in shaping psychological life and interaction. (Benjamin 30)

Benjamin navigates the necessary give and take that exists when binary patterns of subject/object are necessary but also give way to subject/subject interactions as well. Ultimately, Benjamin combats feminist criticism that figures the mother as "object" and as a result, "impedes our ability to see the world as inhabited by equal subjects" (31). In fact, Benjamin argues that "the capacity to recognize the mother as a subject is an important part of early development" (31). Here, Benjamin is concerned with the early development stages of child psychology, but I build on her articulation of intersubjectivity and see the possibility of mutual recognition in adult figures, particularly through the mother. Although articulated in psychoanalysis at a much later date, Benjamin's concept of intersubjectivity, especially as relates to parenthood, circulates in many modernist representations of Victorian parents through the sublime moment that reveals object/other as subject through mutual recognition.

In these texts, birth and parenthood become the specific event that gives the mothers and fathers access to the subject/subject sublime experience. Like death, birth's emotional complexity cannot be conveyed through language and exhibits an experience of terror, awe, pain, and pleasure. Both birth and death offer moments where subjects must consider the nature of subjectivity through proximity to life - either by bringing a child into the world or by exiting the world. In these novels, the person who experiences birth or death does not undergo the sublime experience while his/her other does. These experiences provide moments where social boundaries are breached, permitting an act of empathy that can ultimately transcend into an intersubjective sublime experience. Excluding The Rainbow, these texts do not represent the experience of birth; it is literally beyond the language of the text itself. Instead, these novels 
focus on death, because it is a trope of the sublime that allows the authors to signal a reciprocal sublime experience. However, without parenthood (and hence, at some point birth), these texts imply that the mothers and fathers would not have access to the sublime experience. The socially confining roles of wives/mothers and husbands/fathers create the borders of subjectivity that must be breached in order to create ideologically sublime subjects. ${ }^{6}$ I focus on Victorian parents, overpowered by miscommunication and silence, who have access to the sublime in these novels. These representations of parents are particularly important as they align with a modernist emphasis on looking back toward their Victorian precursors. ${ }^{7}$ Modernism generally shares a similar mistrust of language that is evident in the silence and miscommunication between mothers and fathers in these texts as well as that discussed in theorizations of the sublime. This miscommunication and silence becomes the representational technique that links the marriage/parenthood subjectivities of mothers and fathers to Burkean and Kantian aesthetic theorizations that insist on the failure of language to represent the sublime experience. This silence and the emotional distance it represents signals the sublime moment for mothers.

Similarly, death functions like language because it marks a point beyond representation, a failure to represent life. It is significant that, with the exception of The Rainbow, the older mothers in these novels eventually die, because death functions as a trope in these texts, signaling the sublime to the reader. The death of the mother could be read as a necessary sacrifice to or cost of the sublime experience, but I propose that her death is a trope of the traditional sublime that is used by the authors to signal a new sublime experience-one that reinterprets aesthetics and subjectivity together. This second sublime experience indicates that gendered structures are constantly reciprocated during life, but birth and death mark two moments where social boundaries are thrown into relief as the margins of subjectivity are 
challenged. When the mother dies, the father realizes his complicity in a social structure that has used women to continue their empowerment. At this moment, the father opens to the mother's subjectivity — understanding the limitations his position as patriarch has placed on her wants and desires. Like language as a signal to the mother's sublime experience, death signals the father's sublime experience. Both mark a reciprocal sublime experience that occurs as a result of the interactions between mothers and fathers.

I add to the scholarship that reevaluates gender by exploring the link between aesthetics and parental subjectivity through the concept of the sublime. Most criticism on the modernist literature I examine finds Victorian mother characters as complicit with the oppressive practices of the patriarch. ${ }^{8}$ Critics have often accused male modernist authors of being misogynist or masculinist. ${ }^{9}$ Recently, modernist scholarship has reconsidered simplified readings of gender that ignore the cultural context of the time. ${ }^{10}$ In particular, this reconsideration tries to avoid essentializing notions of gender in favor of more nuanced readings of masculinist attitudes that account for the shifting gender roles of the early twentieth century. My approach reconsiders gender in terms of masculinity and femininity rather than privileging one gendered reading over another. I read these male authors as using the subject/subject sublime experience to question masculinity as represented by the patriarchy in the same way that femininity has been questioned as subject to patriarchal power.

\section{Why Modernism?}

A study on modernism that focuses on an eighteenth-century aesthetic concept may seem a bit odd. That strangeness is certainly compounded by the fact that this study applies the sublime to the novel rather than the poetic form with which it has commonly been associated in British Romanticism. Historically, the rise of the novel genre occurred during the same era as 
British Romanticism and eighteenth-century discussions of the sublime by Edmund Burke and Immanuel Kant. ${ }^{11}$ As a newer genre that had very specific gender dynamics related to domesticity, the novel was immersed in debates about realism, form, and its place in the literary canon. ${ }^{12}$ In particular, the gothic novel in the eighteenth century incorporated the Romantic sublime as revealing particularly gendered constructions of terror related to patriarchy. In the nineteenth century, the separate aesthetic tradition of the novel validates it as a serious literary genre. ${ }^{13}$ By the early twentieth century, the aesthetic discourse of critics like Pound, Eliot, and even Woolf reflected an intersection of literary boundaries typically thought to be separate. The novel form became a new platform to reconsider traditional aesthetics based on rapidly emerging changes in social structure, social discourses, and identity politics. Humanism became a key term in both politics and aesthetics that reflected an ever increasing influence of first wave feminism on social dynamics. ${ }^{14}$ The questions of what it means to be human, of how to inhabit specific identity categories, and of how to think about the self in relation to others are paramount to an understanding of early twentieth-century aesthetics, identity, and subjectivity. As traditional binaries and boundaries collapse, modernist novelists use the genre as a platform to explore the nature of the modern subject and his/her interactions with others. The novel, which traditionally emphasizes the domestic, places importance on the family unit as a small scale social system through which modernist writers can explore the intersection of aesthetics and subjectivity.

In the modernist novel, the family functions as a microcosm or a small scale representation of social issues that play out in emotional relationships. Like imperialism, patriarchy, and aesthetics, the family is a social structure under duress during the early twentieth century; they all work together to reinforce one particular, idealized subject (i.e. white, middle- 
class) that fails to represent lived experiences or "others" outside that system. In As I Lay Dying, Howards End, The Rainbow, and To the Lighthouse, the authors return to the Victorian family as central to representing many of the political and social struggles of the early twentieth century. They use Victorian parents as a way of confronting the present through the past, placing special emphasis on "history" as part of ideological discourse. On the surface, these parents appear to reaffirm gendered Victorian ideological structures. Elaine Showalter has followed this perspective in her readings of modernism, but she often relies on extensive autobiographical information about the authors and their relationships with their parents in order to read Victorian parents in the modernist novel. By choosing the novel over the autobiographical form, the writers in this study distance themselves from a strictly autobiographical or personal reading of their fiction. As a result, their parents may have inspired their literary counterparts, but the function of fiction is to create a larger symbolic meaning that transcends the specific in favor of common human experience. By 1910, the novel is a counterpart to poetry that assumes an intersubjective component rather than an emphasis on individual, ego-centered experience. Although families differ in terms of gender, race, class, and nationality, all families rely on close, emotional interactions between people that draw these identity issues into focus.

The formal experiments by modernist novelists as well as poets place special emphasis on a link between aesthetics and subjectivity. Criticism on aesthetics typically focuses on poetry, as in the work of Lesley Higgins or art as in the work of Michael Leja. Unlike the novel, poetry and art have specific rules about structure and form. Despite their attempts to "break the form," modernist poets still rely on the traditional aesthetic "object" as key to representational form. ${ }^{15}$ William Faulkner, E.M. Forster, D.H. Lawrence, and Virginia Woolf incorporate the poetics of imagism and the abstract meaning of impressionism and expressionism into a narrative form that 
allows for the possibility of subjective rather than objective expression. The adoption of streamof-consciousness narrative technique and free indirect discourse reflect a larger cultural shift that aligns with the development of psychoanalysis. The "scientific" study of the mind and the development of certain identity traits in relation to others is a key focus of psychoanalysis; the same is true of the modernist novel. The formal experimentation in the novel genre uses form to explore how people interact, whether it is possible to know the thoughts of others, and how others influence who one becomes. At its core, the culture of modernism necessitated an exploration of intersubjectivity that was ignored in traditional aesthetics and psychoanalysis.

The influence of Sigmund Freud on early twentieth century scientific discourse, construction of the Victorian family, modernist aesthetics, and the reinforcement of subject/object dynamics cannot be understated. Freud's ideas circulated not only among the scientific/medical community but also in cultural and literary circles. D.H. Lawrence countered Freudian psychoanalysis in his Psychoanalysis and the Unconscious and Fantasia of the Unconscious with his own emotionally driven and sexually charged response. Freud was a topic of conversation at a number of the Bloomsbury group's meetings, which included E.M. Forster and Virginia Woolf, among others. Woolf's diaries express skepticism of Freudian ideas presented at these meetings, but as she begins writing her autobiography, "A Sketch of the Past," at the end of her life, she returns to Freud's works in order to use his theories to explore her relationship with her family. ${ }^{16}$ Since he wrote during a later time period and spent most of his time in the United States, Faulkner had far less to say about Freud, but like the British novelists, he exhibits an interest in and skepticism of Freudian psychoanalysis. In letters, diaries, and criticism, all of these authors show a familiarity with Freudian concepts, including the unconscious, the Oedipus Complex, and ambivalence. All of these writers are interested in 
issues of identity related to sexuality and gender, and through their novels, they present the possibility of intersubjectivity in much clearer and emotional terms than Freud's emphasis on the "ego" and the "self" make possible.

The most important contribution of Freudian psychoanalysis is its emphasis on human interactions as essential to constituting identity even if Freud retreats into patriarchal discourses that continue to objectify women as a validation of the ego or self. ${ }^{17}$ Following gendered ideological discourses regarding the Victorian family, Freud posits the mother as an object while the child (regardless of anatomical sex) constructs his/her subjectivity through his/her interactions with her. Carolyn Dever links Freud's analysis of the mother with her representation in the Victorian novel. Rather than employing a paradigm that reads the Victorian novel through psychoanalysis, Dever suggests that the foundational images of the family employed by Freud stem from fictional rather than lived experiences. The "Victorian narratives of psychoanalysis" duplicate the "narrative paradigms of Victorian fiction" (Dever 39). As Dever argues, "Victorian representational paradigms pose provocative and revealing challenges to the narcissistic empire of the psychoanalytic subject" (3). Building on Dever's connections between the novel form, the representation of the family in Victorian fiction, and its influence on Freudian narratives, the modernist novel becomes the perfect space for the next generation of writers to both employ and critique Freud's theories. These writers suggest that there are gaps and fissures in Freud's discourse of the family related to issues of identity. Dever shows that Freudian psychoanalysis (despite its case studies and claims to objectivity) is already enmeshed in aesthetic practice, especially through the novel form.

From 1910 to 1930, which is the time in which these novels were written, Freudian psychoanalytic ideas were circulating among the general culture as well as in literary circles. 
Although many writers, like Lawrence, were skeptical of Freud, the rise of psychoanalysis drew particular attention to how one understood his/her identity or subjectivity. Freud placed increasing importance on how one's emotional experiences, especially formative experiences from childhood, impacted how one understands his/her self as an adult. The rise of Freudian psychoanalysis at the same time as a drastic shift in literary aesthetics offered a particular historical moment where the "objectivity" associated with aesthetics must suddenly confront the emphasis on subjectivity revealed through psychoanalysis. These novelists are able to combine experimental narrative technique (like stream-of-consciousness) that focuses on subjectivity and rethink the need for distance as a way of exploring the aesthetic object. Ultimately, Freud's idea of the subject results in modernist novelists rethinking of the subject/object dynamic associated with traditional aesthetic theory. What all these writers emphasize in their novels is the figuring of both mother and father as object, but they challenge this "objectification" by promoting clearly intersubjective interactions within the family dynamic. These novelists explore the subjectivity of both mothers and fathers despite their object status to both their children and society. The modernist novel challenges subject/object discourse related to gender and parenthood by connecting psychoanalysis, aesthetics, and narrative form.

\section{A Subjective Correlative: Modernism, Aesthetics, and the Novel}

Traditional aesthetics typically focuses on the "object," including the beautiful object, the object of the gaze, or the importance of realism in representing an object in art. The artist's value is informed by his/her objectivity in presenting the object, and the aesthetic viewer employs an objective eye. In the late nineteenth to early twentieth century, modernist aesthetic discourse still employs objectivity as a catch phrase; however, as abstract techniques become commonplace in both painting and writing, the importance of subjectivity comes to the fore. 
Despite claims of objectivity related to form, art develops a larger emphasis on subjective rather than objective experience or about its ability to convey abstract concepts like emotion or movement. The shift in aesthetic perspective parallels the development of Freud's psychoanalytic theory that examines the formation of subjectivity related to others. Like modernist artists, Freud also claims objectivity for his psychoanalytic method, and he often frames the development of certain identities in terms of objects. Although they focus on different subject matters, psychoanalytic and aesthetic theories use similar subject/object constructions in their discourses. Freud plays the role of objective observer in his case studies as much as the writer or artist plays this role in his/her art. As Georgia Johnston has argued, Freud engages in acts of representation despite his "scientific" approach. ${ }^{18}$ The discourse of representation and perception rely on a subject/object divide that becomes clear in the split between the sublime and the beautiful or the beautiful and the ugly. The modernist preference for the ugly as beautiful reflects a shift away from traditional aesthetics and shows a new emphasis on subjectivity and identity.

The term "modernism" has a specific, Anglo-American aesthetic connotation that is associated with the vast amount of critical writing by Ezra Pound, T.S. Eliot, and Wyndham Lewis and the later institutionalization of the term by critics like Raymond Williams. Recently, the term "modernism" has come under intense scrutiny, because as Edward Mozejko points out, there is no clear, single definition for modernism. This lack of unity reveals itself as the term "modernism" is increasingly applied to texts outside of the Anglo-American modernist canon that the term has traditionally represented (Mozejko 14); it is a term that rapidly deconstructs itself (Mozejko 29). Pound, Eliot, and Lewis constitute what Martin Puchner terms "reargaurdism" or a movement "located within the field of advancement but is skeptical of its most 
extreme practitioners; rear-gaurdism seeks to correct and contain the avant-garde's excess without falling behind and losing touch with it entirely" (45). Puchner's term suggests that these "bad modernists" represent an "unsavory brand of modernism, an amalgam of racial hysteria, homophobic diatribes, fascist politics, and social resentment" (44). The reactionary approach of Pound, Eliot, and Lewis reveals another aesthetic, social, and political approach to modernism that exists outside the boundaries endorsed by the institutionalized "high canon." These men approached modernism from what they termed an "objective" perspective; however, as Heather K. Love reports, "beauty" becomes a key term disavowed by these modernists. She suggests that Pater's discourse on beauty reveals a queer modernist aesthetic that explores an "alternative politics - one consonant with the experience of marginalized subjects" (Love 27). Love argues that Pater's endorsement of beauty is a "politics of refusal" that fails to reproduce the "approximate norms of modernist political subjectivity" (27). In a similar approach, Lesley Higgins examines the disavowal of Pater by Eliot, Pound, and Lewis through their endorsement of the ugly as beautiful. By reifying ugliness, these modernists promote an aesthetics that refuses not only the traditional discourse of beauty endorsed by Pater, but also the association of queerness with the beautiful. As all of these critical approaches show, aesthetic discourse in modernism engages with identity politics, endowing discussions of beauty and its inherent opposite, sublimity, with a sociopolitical context.

For the rear-guard modernists, beauty represented an outmoded theory of art that no longer represented the early twentieth-century subject. In response, Pound, Eliot, and Lewis turn to the ugly in order to refute the importance of form, which is often associated with beauty. Pound insists on breaking the structure of the line of poetry while novelists challenge the form of the traditional narrator with an "objective" perspective. Pound, Eliot, and Lewis reverse the 
formal nature of beauty by investing in the aesthetics of ugliness. According to Lesley Higgins, ugliness reconfigures the terms of beauty so that the ugly or formless is also beautiful. These critics facilitate this collapse by proposing that beauty is subjective rather than objective, placing importance on individual rather than communal taste. Ironically, Pound, Eliot, and Lewis still use the communal standards of taste by creating a "new" discourse about art that reverses the standards of traditional aesthetics; they are right in their critique of beauty as representing an outmoded aesthetic that does not represent modern life. Despite the reversal, they continued to use public discourse as a way of documenting a taste for the ugly as an objective perspective. The fact that they were able to collapse the ugly into the category of the beautiful suggests that taste is subjective, but once the ugly becomes an aesthetic category, they approach it from an “objective" perspective.

Subverting the formal rules associated with beauty, the aesthetics of modernism emphasize objectivity while asserting subjective judgment. In his discussion of beauty in modernism, Theodor Adorno associates the tropes of the sublime with the beautiful, which implicitly undermines the separation of beauty from sublimity and the associated subject/object binary. Adorno aligns Kantian aesthetics and Freudian psychoanalysis as explicitly concerned with subjectivity (9-10), whereas, modernist art explodes subjectivity in favor of objectivity or disinterestedness. Adorno makes his argument through Freud's psychoanalytic reading of the artist figure, faulting psychoanalysis for seeing artwork as "essentially unconscious projections of those who have produced them" (8). For Freud, artists ignore the issue of form or traditional aesthetics in favor of unconscious projections. Adorno supports the objectifying practice of art: "Psychoanalysis treats artworks as nothing but facts, yet it neglects their own objectivity, their inner consistency, their level of form, their critical impulse, their relation to nonpsychical reality, 
and, finally, their idea of truth" (9). Despite Adorno's insistence on the objectivity of modernism, the novelists in this work are rarely consistent in either form or content, and they undermine any concept of objectivity or truth by exploring multiple subjectivities. As Adorno correctly notes, both Kant and Freud are concerned with subjectivity through desire. Adorno examines "aesthetic feeling" and shows that for Kant, "aesthetic comportment is free from immediate desire" (10). Whether showing negative desire (as in Kant) or positive desire (as in Freud), both are "in principle subjectively oriented by the power of desire" (11).

Adorno strengthens the connection between psychoanalysis and aesthetics despite his repeated assertions that Freud and Kant are antithetical to one another. Regardless of his insistence on objectivity in modernist aesthetics, Adorno's reading of beauty actually emphasizes the subjective rather than the objective as beauty takes on the attributes of the subjective sublime. Adorno sees beauty as related to terror and the power struggle over nature:

The image of beauty as that of a single and differentiated something originates with the emancipation from the fear of the overpowering wholeness and undifferentiatedness of nature. The shudder in the face of this is rescued by beauty into itself by making itself impervious to the immediately existent; beauty establishes a sphere of untouchability; works become beautiful by the force of their opposition to what simply exists. Of that on which it was active the aesthetically forming spirit allowed entry only to what resembled it, what it understood, or what it hoped to make like itself. This was a process of formalization; therefore beauty is, in terms of its historical tendency, formal. The reduction that beauty imposes on the terrifying, over and out of which beauty raises itself and which it banishes from itself as from a sacred temple, has-in the face of the 
terrifying — something powerless about it....If beauty is not to fail its own telos, it must work against its enemy even if this struggle is contrary to its own tendency. (51)

Adorno employs the image of beauty as objective, powerless, and consistent, but for beauty to prevail in the face of terror, a subjective power struggle must occur. Adorno objectifies the sublime by collapsing it into the category of beauty, but what he reveals is the subjectivity expressed in and relative to art. In an analysis of the sublime from Adorno's modernism to Lyotard's postmodernism, Peter V. Zima argues that Adorno incorporates the sublime into the beautiful so that it reflects an emphasis on the individuality of the subject. Despite trying to champion the objectivity of modernism, Adorno actually reveals subjectivity as essential to any reading of modernist aesthetics, which emphasized the individual over the collective in its imagining of the modernist artist. The connection between psychoanalysis and aesthetics reveals a cultural slipperiness around both subjects and objects. The inability of modernism to find any definitive form for either objects or subjects reveals the faulty parameters of social discourses that employ these terms.

As the brief references to critics like Walter Pater show, another strain of modernist aesthetics countered the dominant narrative of the rear-guard. This second strain reveals what I term the "subjective correlative," and unlike Eliot's "objective correlative," this aesthetic practice considers subjectivity in direct relationship to the aesthetic practice of objectivity. In particular, the "subjective correlative" considers emotion as directly related to aesthetics despite reaching toward a disinterested stance and emerges in the critical discussion of modern novelists and painters. In his essay "The Artist and Psycho-Analysis," Roger Fry offers another aesthetic possibility for modernism through the emotional. Fry emphasizes the subjective but not in order to reify the individual, which is the fault of Adorno, Freud, Kant, Eliot, Pound, and Lewis. Fry 
suggests that "esthetic emotions" result from an encounter with form that evokes emotions related to objects:

The form of a work of art has a meaning of its own and the contemplation of the form in and for itself gives rise in some people to a special emotion which does not depend upon the association of the form with anything else whatever. But that form may by various means either by casual opposition or by some resemblance to things or people or ideas in the outside world, become intimately associated in our minds with those other things, and if these things are objects of emotional feeling, we shall get from the contemplation of the form the echo of all the feelings belonging to the associated objects. (355)

Fry links emotional response to the consumption of goods in a capitalist society, especially through advertising. Fry uses the marketed or consumable object as a way of establishing a high and low modernist aesthetic; however, he finds the emotional use of advertisers as key to understanding an aesthetic sensibility.

Fry reads the relationship between objects and emotion in order to discuss Freud's psychoanalytic approach to the artist who engages in fantasy and wish-fulfillment. He sees a difference between emotion used as "escape" and a consistent, deep emotion connected to aesthetic form. Fry locates this difference most strongly in the first rate novel compared to the genre novel:

None of these conditions apply to any first-rate novel - the novels that have endured do not represent wish-fulfillment to any considerable extent. They depend on the contrary for their effect upon a peculiar detachment from the instinctive life. Instead of manipulating reality so as to conform to the libido, they note the inexorable sequence in life of cause and effect, they mark the total indifference of fate to all human desires, and 
they endeavour to drive precisely from that inexorability of fate an altogether different kind of pleasure - the pleasure which consists in the recognition of inevitable sequences; a pleasure which you see corresponds to the pleasure which we found in marking the inevitable sequence of the notes in a tune; in fact again a pleasure derived from the contemplation of the relations and correspondences of form. (359)

Fry suggests a subjective component to the novel reflected in the level of form. He reveals an "art which has withdrawn itself from the dream, which is concerned with reality, and art therefore which is pre-eminently objective and dis-interested, and which therefore proceeds in the opposite direction from the other kind of art" (364).

Fry returns to the objective and disinterested as key to modernist aesthetics, but at the end of the essay, he returns to the emotional as key to art:

It looks as though art had got access to the substratum of all the emotional colours of life, to something which underlies all, the particular and specialized emotions of actual life. It seems to derive an emotional energy from the very conditions of our existence by its relation of an emotional significance in time and space. Or it may be that art really calls up, as it were, the residual traces left on the spirit by the different emotions of life, without however recalling the actual experiences, so that we get an echo of the emotion without the limitation and particular direction which it had in experience (365).

The predominance of "objective" aesthetics in modernism is also espoused by Fry, but at the same time, he proposes another strain of emotional or subjective aesthetics that undermines his investment in the objective. Following this line of aesthetics, the modernist novel begins to unravel the importance of form by emphasizing the possibility of sublimity between two people rather than a person and an aesthetic object. 


\section{Conceiving a "Sublime Subject": Understanding the Sublime through Modernism}

As an object of aesthetic inquiry, the sublime is firmly situated in the realm of the indefinable. Located as a counterpart to the beautiful, the sublime experience involves an interaction between representation and subjectivity related to transcendence. In a sublime moment, a person encounters an object that provokes a feeling of awe, terror, and pain, but also a feeling of pleasure. The sublime also depends upon that which cannot be represented, and in literature, it translates to that which cannot be represented in language specifically. A part of this association is, as Edmund Burke originally articulates, that the sublime exists between borders and exceeds boundaries like language, physical death, or mental capacity. Burke's approach to the sublime reflects an empirical emphasis of the eighteenth century, which results in a catalog of the components of the beautiful or sublime object. ${ }^{19}$ Burke's taxonomical or "scientific" account of the components and tropes of beautiful and sublime objects offers a paradox. The empirical approach implies there are essential aspects that make an object beautiful or sublime, but at the same time, the accounting of those objects relies on a viewer. Burke's approach actually underscores the subjective while appearing to retreat into the objective. Immanuel Kant more fully realizes the mental or subjective component of the sublime although he relies on the eighteenth-century philosophical discussions of reason and imagination. Kant presents a more concentrated focus on the mental processes that arise in the person experiencing the sublime rather than emphasizing the empirical components of the sublime object. In either case, both Burke and Kant attempt to understand an aesthetic experience between a passive object that is a representation (like a piece of art or a view of nature) and an active subject.

Burke's articulation of the sublime, especially through comparison and contrast with the beautiful, creates an aesthetic discourse that polarizes into the beautiful/sublime binary. If a 
beautiful object is smooth, the rough object is sublime because it promotes inconsistency. If a beautiful object is light, the sublime object is dark or represents darkness. Burke continues this approach throughout much of A Philosophical Enquiry into the Origin of Our Ideas of the Sublime and Beautiful. As an extension of this binary approach, Burke explicitly associates the beautiful with the feminine - thereby implicitly associating the sublime with the masculine. Burke's examination of the sublime does occasionally take a less empirical and a more psychological approach, showing the importance of the "mind" in the process of sublime aesthetics. Part of this psychological interpretation results from Burke's examination of distance as a key component between the subject/object interactions of the sublime. In particular, Burke insists that the sublime is the "strongest emotion which the mind is capable of feeling" (39). By making this statement, Burke contradicts his empirical project but also creates the loophole in the sublime that allows the experience to be analyzed in terms of emotion. The sublime emphasizes subjectivity more than aesthetics since its key components reside in the mind or in the subject. A central tenet of aesthetics insists on the objectivity of the viewer in assessing the form of art. For Burke and Kant, form closely aligns with beauty through harmony of line and contour; the beautiful suggests a perspective that relies on emotion, particularly pleasure, which makes it more subjective. Feeling and the importance of perception sit at the periphery of the sublime, suggesting a concern for subjective components of art. ${ }^{20}$ The importance of distance in the sublime makes the viewer appear disinterested through the act of reflection. In actuality the intervention of "objectivity" through emotion, imagination, or even reason always already makes the sublime subjective.

Kant recognizes a separation between Burke's empirical and psychological assessments of the sublime, and as a result, Kant divides the sublime into yet another binary: the 
mathematical sublime and the dynamical sublime. The mathematical sublime accounts for Burke's more empirical discussions of the sublime; however, Kant emphasizes magnitude and infinity to a much larger degree than Burke. Kant writes, "All estimation of magnitude of objects of nature is ultimately aesthetic (i.e., is determined subjectively rather than objectively)" (107). Kant uses magnitude in order to bring in the issues of perception and subjectivity. Kant terms this as the difference between apprehension and comprehension: "For when apprehension has reached the point where the partial presentations of sensible intuition that were first apprehended are already beginning to be extinguished in the imagination, as it proceeds to apprehend further ones, the imagination then loses as much on the one side as it gains on the other; and so there is a maximum comprehension that it cannot exceed" (108). Imagination intervenes in the mathematical sublime, offering the comprehension of that which is immeasurable. Sublimity functions through subjectivity, which Kant articulates in terms of apprehension and comprehension. Finally, Kant completes the connection between the mind, the sublime, and the object: "[A] substrate that is large beyond any standard of sense and hence makes us judge as sublime not so much the object as the mental attunement in which we find ourselves when we estimate the object" (112). Kant develops the psychological components of Burke's sublime by focusing on how the subject interacts with the sublime object. In particular, he suggests that sublimity lies in the subject rather than an object. As a result, Kant spends far less time in his text detailing the attributes of objects that are beautiful or sublime in favor of reading how the mind functions or feels during the sublime experience.

Kant's discussion of the dynamic sublime realizes the psychological components of Burke's sublime and articulates the emotional responses of the sublime as purely a mental process, resulting in the interaction between distance, understanding, and imagination. For Kant, 
the dynamical sublime is best represented in Burke's discussion of watching a shipwreck or a thunderstorm from a distance. By emphasizing the distance between the subject and the object of the subject's gaze, Kant more fully realizes the internalized process of perception related to sublimity. The dynamic sublime navigates the area between both pain and pleasure, because it emphasizes a "might" that cannot dominate the subject. Kant examines the dynamically sublime in nature: thunderstorms, volcanoes, hurricanes, "boundless ocean heaved up," or "high waterfalls" (120). Of the viewer's response to these terrifying forces of nature, Kant writes,

Compared to the might of any of these, our ability to resist becomes an insignificant trifle. Yet the sight of them becomes all the more attractive the more fearful it is, provided we are in a safe place. And we like to call these objects sublime because they raise the soul's fortitude above its usual middle range and allow us to discover in ourselves an ability to resist which is of a quite different kind, and which gives us the courage that we could be a match for nature's seeming omnipotence. (120)

In this description, distance becomes the key component that provides both pleasure and pain in the sublime experience. The subject recognizes a might larger than the self, but at the same time, the subject can realize the mind's limited ability to conceive of that might. The subject realizes the mind's limit as a result of its distanced perception, an act Kant associates with reason, a masculine attribute. Through this interaction with nature, omnipotence conflicts with the mind, and through reason, the subject realizes the possibility of his/her superiority over nature. ${ }^{21}$

Although he takes the sublime in a new direction, Kant also develops his Critique of Judgment using the binary between the sublime and beautiful that Burke employs, and he continues to invoke Burke's gendered association of the beautiful with the feminine and the sublime with the masculine. The theorization of the sublime is one that is only open to 
masculine discourse, because women, who invoke the beautiful, do not explicitly have access to the discourse of the sublime itself. Kant's critique is invested in a cultural gender dynamic that is transposed onto his beautiful and sublime binary in much the same way as that of Burke. Burke combines the beautiful with sex, passion, and attraction: "The object therefore of this mixed passion which we call love, is the beauty of the sex. Men are carried to the sex in general, as it is the sex, and by the common law of nature; but they are attached to particulars by personal beauty" (42). For Burke, men, not women, are invested in "love," which revolves around a beautiful object, a woman. Later in his treatise, Burke examines the connection between proportion in the human species and beauty. Although he admits that beauty is possible for both sexes, Burke places particular emphasis on the feminine form: "But are these proportions exactly the same in all handsome men? or are they at all the proportions found in beautiful women? nobody will say that they are; yet both sexes are undoubtedly capable of beauty, and the female of the greatest; which advantage I believe will hardly be attributed to the superior exactness of proportion in the female sex" (97-98). Burke genders the beautiful as feminine, especially as related to proportion and form; he relies on the reduction of the feminine to bodily rather than mental attributes.

As Barbara Claire Freeman suggests, like Burke, Kant also engages in a gendered binary between the beautiful and sublimity, but his prose is far less overt. Kant writes,

But from this standard idea of the beautiful we must still distinguish the ideal of the beautiful, which for reasons already stated must be expected solely in the human figure. Now the ideal in this figure consists in the expression of the moral.... Now it is true that this visible expression of moral ideas that govern man inwardly can be taken only from experience. Yet these moral ideas must be connected, in the idea of the highest 
purposiveness, with everything that our reason links with the morally good: goodness of soul, or purity, or fortitude, or serenity. (83-84)

By invoking the moral, Kant genders the beautiful by linking it with social concepts typically associated with women (i.e., purity, goodness), especially white, middle-class, religious women. Although he refrains from extensive conversations about the beautiful and the "fairer sex," Kant still constructs the beautiful in terms of social discourse. Freeman argues for "a reading of the sublime as an allegory of the construction of the patriarchal (but not necessarily male) subject, a self that maintains its borders by subordinating difference and by appropriating rather than identifying with that which presents itself as other" (4). Freeman sees the discourse of the sublime as one that continues to demand the subjugation of the feminine to the masculine. Both Burke and Kant appropriate the feminine in order to control it rather than articulating a concept of difference that allows excess. Freeman articulates the feminine sublime as that which represents an encounter with otherness that cannot be represented and is located in "excess.",22

Freeman reads Burke's control of the feminine in the process of speculation that imposes a masculine gaze through capitalism, and she reads the appropriation of the feminine by Kant through an association of the imagination with the feminine. She argues that the feminine as beautiful and masculine as sublime binary continues in Kant's discourse since the imagination must be sacrificed in the sublime experience. Freeman reads Kant's imagination as scapegoated to reason or a "collapse of imagination's capacity to connect empirical reality with the realm of abstract ideality, and reason's subsequent amplification occurs only because the imagination has been unable to comprehend reality" (69-70). The imagination must submit to reason, which reflects gender ideology that reinforces the idea of the feminine as weak. Later, Freeman summarizes, "[T]he reason woman is for Kant always associated with the beautiful and never 
with the sublime, is that her subjugation is its very precondition" (72-73). Freeman reads Kant's sublime as a form of internalized oppression related to patriarchy and necessary in order for patriarchy to reproduce. Freeman expertly links the gendering of social and historical discourses to the critical framework of the sublime and beautiful, especially in the work of Burke and Kant. She explores the subject/object relationship between aesthetics and gender in its traditional terms and reveals the significance of cultural discourses like gender that sculpt "objective" aesthetics.

Anne K. Mellor considers a less traditional approach to gendered sublimity related through women's writing, especially in gothic novels like those of Ann Radcliffe where daughters internalize oppression through confrontation with the terror produced by their powerful, imposing, patriarchal fathers. Mellor suggests a rewriting of the sublime from an intersubjective experience where the sublime object is a person; she explores the gendering of "nature" as feminine and beautiful in these texts. By analyzing the representation of nature, Mellor challenges the masculine, usually termed egotistical, concept of the sublime associated with male poets like William Wordsworth. ${ }^{23}$ In masculine romanticism, nature becomes a key component of the sublime, but the masculine sublime experience itself is an "epistemological relationship of the perceiving mind to the object of perception" (85). Like Freeman, Mellor reads the masculine sublime as one of empowerment that demands the feminine to be either suppressed or sacrificed, which results in the terror daughters feel when confronted with their fathers in the gothic household. Mellor's discussion of the gothic sublime and patriarchy proposes a new sublime terror that is located in the domestic rather than in nature. She argues that this sublime is developed in a feminine romantic tradition, and the terrors depicted are understood as a power struggle between a subjugated other, the daughter, and the patriarch, the father, in terms of the father-daughter incest taboo. ${ }^{24}$ The patriarch, an object, has the power to 
violate the incest taboo and produces the terror necessary for the daughter to experience a sublime moment. The patriarch fulfills the role of "object" and empowers women writers by reversing the terms of gender discourse. It is men (not beautiful women) who are objectified. Drawing on Mellor's location of the sublime in the domestic and the family, I identify a continuation of this practice in the modernist novel. Faulkner, Forster, Lawrence, and Woolf objectify both fathers and mothers in sublime experiences located in the Victorian home.

Through Lacanian psychoanalysis, Slavoj Žižek assesses Burke’s and Kant’s arguments by examining the sublime object in relation to its ideological function, which locates the sublime as negativity related to the "modern" subject's interaction with social roles and norms. Žižek writes that " $[\mathrm{t}]$ he Sublime is an object in which we can experience this very impossibility, this permanent failure of the representation to reach after the Thing. Thus, by means of the very failure of representation, we can have a presentiment of the true dimension of the Thing" (Žižek 229). In his critique and analysis, Žižek focuses on objects traditionally associated with the sublime like nature, art, and literature. The "Thing” for Žižek is always an object that represents a transcendental signified. Žižek's project is mostly concerned with political structures, but using this approach, he points to how a person, like a king, can function as an ideological sublime object. The king is the figurehead that maintains the apparent transcendence of a monarchial political structure. Sublime objects, like money, provoke the sublime experience for a subject by failing to represent the complexities of ideological structures, like capitalism, that ultimately create the subjects the sublime objects invoke. Žižek's discourse maintains the traditional subject/object terminology of Burke and Kant and transfers that binary into subjectivity. Even when a sublime experience occurs between two subjects, as Anne Mellor articulates between a daughter and her patriarchal father, one of the subjects is presented as an 
object, which echoes the subject/object dynamics of Lacanian psychoanalysis in his articulation of the woman as "other." 25 This also explains why Žižek's "sublime object" reiterates subject/object discourse since it relies heavily on Lacanian psychoanalysis. By focusing on ideology, Žižek explores how multiple identities are constructed through encounters with objects but also points to issues of subjectivity. As a Marxist critic, Žižek focuses on political and capitalist functions of ideology; however, his approach to the "sublime object" can be applied to other identity categories outside of class.

Žižek's emphasis on Lacanian psychoanalysis suggests alterity as an always already present component of the sublime, which is a critique of critical readings of the sublime as only "egotistical."26 At the end of The Sublime Object of Ideology, Žižek explores the process of sublimation through the conflict between "essence," which "presupposes itself as its own other, in the form of externality, of something objectively given in advance" (256), and "appearance." Žižek writes, "[W]e can speak of the difference, the fissure separating the essence from appearance...only, that is, in so far as the essence presupposes itself as something alien, as its own Other" (257). Žižek goes on to suggest that "essence" is key to determining the subject:

This self-fissure of the essence means that the essence is 'subject' and not only 'substance': to express this in a simplified way, 'substance' is the essence in so far as it reflects itself in the world of appearance, in phenomenal objectivity; it is the movement of mediation-sublation-positing of this objectivity, and the 'subject' is substance in so far as it is itself split and experiences itself as some alien, positively given Entity. (257)

Here, Žižek implies a complicated idea of "objectivity” that actually reveals subjectivity and suggests an "alterity" in the sublime as related in ideology. In other words, the conflict between essence and appearance reveals the complicated interaction of the subject in ideology that 
implies an intersubjective component to the sublime through interaction with the Other. Žižek, though, returns to Hegelian and Kantian constructions of both the sublime and ideology and maintains a reading of the sublime that is "egotistical" and relies on reason. In essence, Žižek anticipates intersubjectivity in the sublime, especially as correlates with ideology; however, he does not consider how emotion functions in this equation. By reiterating the terms "subject" and "object," Žižek's discourse maintains a clinical approach to the sublime that marginalizes the importance of emotion in both the sublime experience and the experience of a subject in an ideological structure.

Mellor employs a feminist critical approach in her configuration of the "sublime object" as related to feminine subjectivity. Recently, Lee Edelman explores the "sinthomosexual," a queer subject that functions as a "sublime object"; however, Edelman does not refer to him as such despite invoking Kant, Lacan, and Žižek. Edelman draws on Lacan's "sinthome" or symptom, which represents jouissance and the unanalyzable related to nothingness. The sinthomosexual is a person who functions in the place of jouissance; the queer figure becomes the space of rupture that provokes a sublime-like epiphany for the heteronormative subject. Like Mellor, Edelman's concept of the sinthomosexual is similar in its psychoanalytic constructions as that of Žižek's "sublime object." This queer subject, though, does not function as a subject but rather as a passive object that produces a boundary defying, and hence queer, experience for a heteronormative subject. Edelman's theoretical apparatus for discussing the sinthomosexual is not only psychoanalytic but heavily grounded in aesthetics. Of queerness, Edelman writes in his polemic "that taking the Symbolic's negativity to the very letter of the law, that attending to the persistence of something internal to reason that reason refuses, that turning the force of queerness against all subjects, however queer, can afford an access to the jouissance that at once 
defines and negates us" (5). In his discussion of the queer specifically, Edelman continues by insisting that the subject's access to jouissance "can expose the constancy, the inescapability, of such access to jouissance in the social order itself, even if that order can access its constant access to jouissance only in the process of abjecting that constancy of access onto the queer" (5). This jouissance that Edelman reads as "queer" can also be read as the sublime experience.

As Edelman's work asserts, the queer emphasizes the nothingness located everywhereeven in a person. In a similar move, Žižek deconstructs the Kantian sublime into nothingness based on a psychoanalytical reading that stems from Lacan: "[T]he Sublime is no longer an (empirical) object indicating through its very inadequacy the dimension of a transcendent Thingin-itself (Idea) but an object which occupies the place, replaces, fills out the empty place of the Thing as the void, as the pure Nothing of absolute negativity - the Sublime is an object whose positive body is just an embodiment of Nothing" (234). Like the sinthomosexual, the object of the sublime invokes a moment of recognition that breaks binary thinking into an issue about representation as an "embodiment of nothing." For Edelman, this boundary defying moment queers the heteronormative social structure, and there is a moment that ruptures representation through jouissance. Ultimately, Edelman's sinthomosexual is an object, with no real discussion of his/her queer subjectivity; s/he is simply an object meant to produce the sublime experience for a heteronormative person. In constructing the sinthomosexual in such a manner, Edelman effectively ignores how this encounter might affect the queer subject, making the queer figure an "object." Žižek and Edelman use the sublime to connect the "object" to ideological and identity constructions. Both explore the collapse of the subject/object dynamic through representation and its connection to nothingness. Drawing on their work, nothingness is the platform on which identity is constructed and performed. 
Although his argument explicitly devalues reproduction, especially as it relates to the rhetoric of the future, Edelman's "sinthomosexual" offers an intriguing complement to the notion of the maternal sublime subject. This notion promotes queer figures that need no empathic connections with others who are different and as such encourages an inhuman quality. Edelman suggests that the sinthomosexual is a figure who is the "formalization of a resistance to the conservation of forms, the substantialization of a negativity that dismantles every substance" and leads toward jouissance (Edelman 109). Through the resistance of forms (both ideological and aesthetic), the sinthomosexual exposes a dismantling negativity that moves toward jouissance, revealing the same rupture evident in the sublime. In essence, the sinthomosexual is assumed to be an enlightened figure who will reveal the transcendent ideology of the rhetoric of futurism to those who engage in reproduction and are invested in heteronormativity. Edelman's configuration of the sinthomosexual as an object effectively minimizes the possibility of intersubjectivity and implicitly reinforces a continuation of self/other and subject/object thinking. Although it might seem odd to employ Edelman in a project about reproduction, Edelman actually follows in a tradition that continues to configure the "other" (in this case a queer figure) as an object. In trying to shame reproduction, Edelman ultimately denies any subjectivity to the sinthomosexual figure. He implicitly suggests that the queer figure is an object whose subjectivity must be sacrificed in order to enlighten heteronormative society. This figuration aligns with the discourse surrounding the mother whose abject status makes her ripe for sacrificing in order to maintain patriarchal ideology. Just as Edelman sacrifices the sinthomosexual figure, an object, in order to maintain the possibility of rupturing heteronormative ideology, so too do the modernist authors of this study sacrifice maternal bodies to rupture patriarchal ideology. In fact, Edelman abjects and sacrifices the queer figure in order 
to maintain a new, queer ideology of "no future." Therefore, despite the uneasy fit, Edelman's theory allows us to see how an abject figure can assert an ethical stance that in turn correlates to the maternal sublime subject.

Joanna Zylinska proposes a more ethical solution to the sublime through her articulation of a feminine sublime that attempts to work outside of essentialist gender discourse. Zylinska writes that the "discourse of the sublime has always relied on femininity as its foundation, but it has been a fantasized, stylized version of femininity, something that has allowed the male artist or philosopher to feel complete and undisturbed by the signs of alterity" (173). In response to both the feminist écriture feminine, a circular, feminine language that defies a linear, masculine language, and the traditionally masculine discourse of the sublime, Zylinska proposes the term décriture feminine, which is "a discourse which does not capitalize on difference, and which embraces femininity as a mark of non-binary difference" (Zylinska 39). Décriture feminine creates a "transgression, crossing over of the boundaries drawn for the maintenance of the self's identity" (Zylinska 39) that offers an ethical solution to binary thinking and subject/object discourse. By recognizing and accepting difference or alterity rather than trying to master it, which is what the masculine discourse of the sublime relies upon, the binary structure collapses and the sublime experience becomes ethical rather than privileging one sex over another. The focus on "alterity" in Zylinska's work emphasizes an intersubjective component to the sublime that is implied by Žižek but never explicitly explored. Zylinska suggests that "alterity" is key to an ethical reading of the sublime, and she reads the sublime as engaging with the Other. Zylinska's ethical solution accounts for the idea that gender is performative, and as a result, she uses the collapse of boundaries as a way of thinking ethically. Instead of either/or or right/wrong (as is used in moral systems), ethics implies an in-between position that accounts for the 
possibility of multiple subject positions. Zylinska's ethics relates to the possibility of intersubjectivity as a way of opposing not only either/or but subject/object thinking. Zylinska uses difference as a way of approaching the performance of identity. Rather than using strategic essentialism, which relies on binary difference, Zylinska embraces a discourse that disrupts the self/other binary, suggesting sublimity as the moment of rupture. Following Zylinska, I see a more ethical sublime emerging in an intersubjective conception of family represented in these modernist novels.

\section{Gendering Family: Rewriting Sublimity through the Freudian Victorian Family}

Modernist writers grapple with the complexities of depicting the family - a family that, by the late nineteenth and early twentieth centuries, is under duress due to the rapidly changing nature of gender structures, sexuality, and a constant doubt about national and social ideological structures that reinforce one particular, idealized subject. As a result, many modernist writers return to the idealized, ideological image of the Victorian family, and especially Victorian parents, as a way of confronting the present through the past. Part of the reason that gender becomes a central focus for modernist writers is due to the changing discourse surrounding gender as a result of the women's rights movements, psychoanalysis, and sexology. The scientific discourses at the time attempt to use empirical science in order to make biology align with Victorian gender roles that were the backbone of the public/private social structure. ${ }^{27}$ When male writers attempt to represent women, feminist critics like Elaine Showalter, Sandra Gilbert, and Susan Gubar have relied on essentialist critical approaches to male texts that read attempts by male authors to give voice to female subjectivity as an act of co-optation. As a result, feminist criticism often continues to conform to the idea that only women's literature gives access to women's history. Interestingly, these critics rarely consider how female writers may 
also be co-opting male subjectivity in their attempts to represent patriarchy. In fact, much like the male writers of the time, the depiction of men as patriarchs is often flat and underdeveloped, recognizing none of the emotional struggles that men faced as a result of rapidly changing constructions of masculinity— particularly after World War I. ${ }^{28}$

As they look back toward the Victorian era, modernist writers constantly represent the private sphere as a way of examining an overall crisis in gender rather than just that of femininity. As a result, the idealized Victorian "Patriarch," epitome of stern and emotionally detached masculinity, was more often a symbolic construct that reinforced larger social and national ideologies that maintained class and gender boundaries. Recent historical work by Trev Lynn Broughton, Helen Rogers, Megan Doolittle, Matthew McCormack, and Ben Knights show that the Victorian ideals of breadwinner Patriarch and Angel of the House were in fact images created by various discourses that validated the idea of women's oppression while lived experiences by Victorian families show this model to be untrue. As a result, gender roles themselves do not undergo any drastic reimagining; it is the discourses about gender that bring the subject to the fore. Scientific approaches to gender attempt to reaffirm a discourse driven and ideological construction of women that validates an already imaginary patriarchal societal structure. This becomes especially true as gender discourse rapidly shifts during the turn of the century and as women debunk Victorian femininity by using discourse as a way of demanding more rights and freedoms in terms of work, sexuality, reproduction, and education. ${ }^{29}$ In terms of access to public discourse and institutional rights (like education or voting), there is an actual legal shift in women's rights in both England and the United States; however, the legalization of those rights and the discourse of the women's movement itself emphasizes the fact that gender roles and categories had not been stable during the nineteenth and early-twentieth centuries. 
As a result of the above mentioned social changes and conditions, the idealized images of the Victorian Angel and the Patriarch begin to collapse as the discourse surrounding gender changes in such a way that social institutions, norms, and constructions are consistently challenged by the emotions and feelings of the modern subject. The children of the Victorians begin to write into literature, a discourse, a conflicted version of the patriarch, who is spatially, physically, and emotionally displaced through his location in the private sphere. As he reconsiders Lytton Strachey's Eminent Victorians, Simon Joyce aptly points to inherent contradictions that are revealed through the act of reflecting on the "Victorian period itself as internally fractured and the popular image of it as coherently one-dimensional as part of the mythology that surrounds it" (34). Like Strachey's rewriting of the Victorians, a reconsideration of Victorian mothers and fathers also reveals the disconnect between image and lived experience that undermines simple readings of modernist literature that look backward as either reinforcing or condemning Victorian attitudes, mores, and social structures. ${ }^{30}$ My ultimate point is that during the Victorian time period, masculinity and femininity are constructed as absolute symbolic objects that rarely reflect the lived attitudes, experiences, and relationships that existed in the Victorian family. As gender roles shifted more strongly away from these Victorian ideals, writers began to reflect on what exactly those gender ideals and roles were and how they lead to such polarized notions of masculinity and femininity that left both men and women feeling trapped in the early twentieth century.

Central to discussions of gender at the turn-of-the-twentieth-century is the issue of sexuality and birth, especially as regards women's bodies in the discourse of first wave feminism. During the late nineteenth century, wives sought greater control over their bodies as they began refusing sexual privileges to their husbands in order to avoid the constant physical 
and mental strain on their bodies as a result of pregnancy. Continuing into the twentieth century, these rights stretch even further as birth control advocates like Margaret Sanger become more vocal about controlling the size of families. ${ }^{31}$ The work of early feminists regarding reproductive rights affected attitudes toward sexuality and family structure. These attitudes reflected the following cultural changes: 1) a decrease in family size that reflect both women's refusal to have more pregnancies and a shift in economic and home structure that often meant children were financially supported by parents into late adolescence, 2) an undermining of patriarchal authority as women gain rights to their own bodies both socially and legally, and 3) a decrease in the deaths of mothers due to pregnancy. The importance of birth and the family to the discourse of the women's movement might suggest why these modernist writers convey a subject/subject interaction between parents. As the idealized (and often imaginary) family structure destabilized in the early twentieth century, these writers attempt to find meaning in social institutions like marriage that created social tension and oppression. At the root of gender controversies is a change in "perceived" family structure, which is why modernist critiques of gender roles are heavily embedded in empty symbolic representations of Victorian parents.

\section{Overview of Chapters}

The overall aim of this project is to reveal the intersubjective reimagining of human relationships in the modernist novel. In As I Lay Dying, William Faulkner explores the subjectivity of the mother in relation to acts of violence. By exploring acts of physical violence as well as ideological violence, Faulkner shows the multiple ways that the construction of the mother figure's subjectivity has been subject to gendered discourses. By drawing on Giorgio Agamben's concept of "homo sacer," I examine how Addie is "mater sacer"- the sacred mother whose sacrifice is necessary for the survival of the community. By fulfilling the role of "homo 
sacer," Addie, a mother, actually functions as a "sublime object" and reveals the both abject and sacred status of the mother's body in a patriarchal society As the two roles overlap, Addie is revealed as a "sublime subject," which moves toward a more ethical and intersubjective understanding of the sublime.

In juxtaposition to how Faulkner explores the subjectivity of the dead mother figure through violence, E.M. Forster also examines the complicated emotional impact of the mother figure in provoking the sublime experience. Drawing on recent queer theory that has focused on the history of marriage related to state and legal structures, I examine how Howards End represents the complex relationship between marriage, property, and gendered oppression. I assert that by drawing attention to the parallels between the mother's body and the house, Howards End, as a legal body, Forster represents the transcendent ideological function of the Žižekian "sublime object." In doing this, Forster reveals a queer version of the family that requires intersubjective relationships that transcend social rules regarding constructions of kinship, gender, marriage, and class. More specifically, I explore how Lee Edelman's construction of the "sinthomosexual" applies to articulations of the sublime in a heteronormative setting and align that figure with the abjected, maternal body of Mrs. Wilcox. For Forster, the sublime moment lies in the revelation of the desires of Mrs. Wilcox - the mother figure whose orchestrations both in life and death make a queer family possible.

Unlike Faulkner whose misogynist position has been complicated by recent reexaminations of his work and Forster whose position as a queer writer reveals his sympathy with others outside of heteronormative society, the academy still considers D.H. Lawrence as a masculinist and misogynist writer. Although all of these male writers can be faulted for misogyny at different points in their career, D.H. Lawrence's reputation has remained negative 
despite his paradoxical representations of gender and sexuality. Ironically, of all the writers in this dissertation, including Woolf, Lawrence presents the most intersubjective relationship in terms of gender dynamics. In The Rainbow, Lawrence shows the interactions among three generations of the Brangwen family from courtship through procreation. By following three generations, Lawrence shows the changing gender dynamics from early to mid-nineteenth century and then early twentieth century. In this chapter, I explore the two representations of marriage in the novel in the pairings of Tom and Lydia and Anna (the daughter) and Will. By tracing these two couples, Lawrence reveals the restrictions placed on gender roles at the apex of the Victorian era. Ultimately, by revealing a more companionable relationship between Tom and Lydia, Lawrence proposes a return to more fluid ideas of marriage and gender that allow for the exploration of the other's subjectivity as a moment of emotional transcendence. I argue that Lawrence proposes an intersubjective sublime experience that is revealed through the act of procreation, transcending the expected constructions of marriage and gender roles.

Although this project mostly addresses male authors, I conclude this study with a chapter on Virginia Woolf's To the Lighthouse. Since Woolf is often hailed as a foundational feminist critic and scholar, critical responses almost always focus on her feminist project that reveals the oppression of women by patriarchal society. In comparison to Lawrence, Woolf also explores the possibility of an intersubjective sublime experience; however, for Woolf, this experience occurs between women rather than women and men. I examine how Woolf represents the intersubjective sublime moment through Lily's attempts at creating art. By embedding an artist figure in the text, Woolf explicitly confronts the subject/object dynamics associated with aesthetics with the revelation of subjectivity in relation to family dynamics. Ultimately, I 
suggest that perhaps Lawrence reveals the most revolutionary rewriting of the sublime as it transcends gendered social barriers and allows for a connection between the sexes.

Together, these modern novelists challenge literary, philosophical, and cultural discourses in order to reveal alternate constructions of human interaction that avoid the objectifying impulse reified by patriarchal society. More importantly, these writers show a transatlantic practice that reevaluates the construction of family and especially parenthood for the twentieth century as part of an ethical aesthetic that promotes intersubjectivity. Considering the many challenges to poststructuralist and particularly feminist theory in the last twenty years, I situate this project as part of feminist scholarship that is a reaction to the changing gender dynamics that have occurred since second wave feminism. Ultimately, this project seeks refuge in the idea that a "we" is stronger than an "I" and that subjectivity is a positive force when shared rather than objectified into the concept of the "other." The Modernist Sublime suggests that the desire for more fluid constructions of gender, especially as applied to the expectations of parents, makes the early twentieth century such a dynamic, contradictory, and innovative era. 


\section{Chapter Two}

Mater Sacer: Addie as Sublime Object in William Faulkner's As I Lay Dying

Addie Bundren's body is a spectacle in both William Faulkner's As I Lay Dying and critical responses to the novel, which focus attention on how different communities perceive the presence of Addie's rotting corpse Ted Atkinson suggests that the physical decay of Addie's body affords an allegorical reading of the Yeomen farmer in the United States during the Great Depression (177). Deborah Clarke argues that Faulkner's visual representation of Addie's body reveals that "maternal authority, especially when aligned with the corporeal body, challenges the dominance of language... When the 'phallic, linguistic symbolic establishment' fails to suppress maternal authority, it reveals the precariousness of its own power and definition" (5). Obviously, Addie's body is not only a spectacle, but an object of much ideological speculation. Addie's mothering has also drawn much negative critical attention, which Marc Hewson rereads as Faulkner providing "a composite Addie, a set of maternal ideas and ideals to counter and perhaps overcome the negative patriarchal view that Anse and Addie's father embody" (557-558). Drawing on how Addie's body functions as an object of speculation in the novel, I explore how violence done to Addie's corpse (her dead, physical body) is a metaphor for the violence done to Addie's ideological body during her life. The violence enacted on Addie's corpse reveals the violence imbedded in ideological construction, which in this case, is the ideology of motherhood. She is "mater sacer." The sacred mother, who like "homo sacer," is condemned as unclean. She cannot be sacrificed, but she can be killed. Unlike "homo sacer," "mater sacer" reveals the abject nature of the mother, which requires her sacrifice in order for patriarchal ideology to function. In the novel, Addie's natural death provides the catalyst for a communal cleansing through the ritual of transporting her body to Jefferson-replete with repetitive chanting. Addie's body functions as a "sublime object" whose sacred position mediates the ambiguity 
between pain and pleasure in life - a key aspect of the sublime. This ambiguity, expressed through familial and communal violence, suggests a shift from object (the mother's body) to subject (the mother's desires). I argue that Addie makes the tension between being the object of other's desires and the subject of her own desires apparent by functioning as both "homo sacer" and "sublime object." By functioning as "homo sacer," Addie becomes a "sublime object" for the community. But, by being both "homo sacer" and a "sublime object," the two terms collapse to reveal the mother or "mater sacer" as a "sublime subject" or a person whose presence draws attention to her subjectivity rather than her objectivity as the foundation for the sublime experience. This ethical revelation occurs as her family and the larger community confront and accept her subjectivity as both including and excluding her position as a mother.

Although seemingly two vastly different concepts, "homo sacer" and the "sublime object" follow similar constructions when applied to ideology. "Homo sacer," a term stemming from the Roman judicial system, is a man, who has been deemed unclean, and as a result, he is unworthy of sacrifice; however, if he should be killed, it would not be considered a homicide (Festus qtd. in Agamben 71). As Giorgio Agamben shows, the concept of "homo sacer" addresses life but not the body:

[M]odern democracy’s specific aporia: it wants to put the freedom and happiness of men into play in the very place_- "bare life"- that marked their subjection. Behind the long, strife-ridden process that leads to the recognition of rights and formal liberties stands once again the body of the sacred man with his double sovereign, his life that cannot be sacrificed yet may, nevertheless be killed. (10)

Agamben's passage shows that the body of the sacred man paradoxically draws attention to the need for rights but the very sacrifice denies the subjectivity and rights of "homo sacer." At its 
foundation, "homo sacer" reveals the paradox between the necessary sacrifice of a physical body to feed the needs of the ideological body.

In his formulation, Agamben posits the "bare life" as linked to the corporeal body while the citizen is a figuration of the political body that is dependent on language. Agamben suggests that "The fundamental pair of Western politics is not that of friend/enemy but that of bare life/political existence, zoe/bios, exclusion/inclusion. There is politics because man is the living being who, in language, separates and opposes himself to his own bare life and, at the same time, maintains himself in relation to that bare life in an inclusive exclusion" (8). Agamben's remarks imply a separation between the lived body or "bare life" and the ideological body, which for him, is the political body revealed through citizenship practices. In addition, language and in this case legal language or law becomes the practice through which inclusion and exclusion from ideological structures occurs. In As I Lay Dying, Addie's corpse and her ability to employ language from beyond the grave draw attention to the very tension between exclusionary and inclusionary practices. Her physical body is killed and excluded, because she is the abject mother whose body is everywhere killed but not formally included through sacrifice. Addie's questioning of language as regards the construction of parenthood reveals the exclusionary practices situated in the construction of the family as an ideological unit. Addie's "bare life," her body, functions literally as the body of reproduction. For her, the "bare life" of motherhood is always at odds with the ideological roles linked to gender. The mother offers a gendered critique of Agamben's work as she, like "homo sacer," serves as an abject figure related to her "bare life," her corporeal body. Agamben focuses on a particular Roman Law and defines his work literally around the sacred man. In essence, the mother fulfills the role of "mater sacer," because her body makes her an abject figure. As I Lay Dying also reveals the acceptance of violence 
inflicted on the maternal body results from her abject position. The rupture of the tensions between mother, body, violence, and ideology configure the sublime moments in As I Lay Dying.

For Agamben, the physical body may be killed, but the ideological body, or life, is endowed with meaning regardless of death, suggesting a transcendent quality to this figure. The life of "homo sacer" preserves an ideology while the existence of the killed body represents the very problems that ideology inherently contains. "Homo sacer" is in essence a "sublime object," who represents a transcendent ideal. (Or perhaps taboo is more apt.) According to Edmund Burke, "Whatever is fitted in any sort to excite the ideas of pain, and danger, that is to say, whatever is in any sort terrible, or is conversant about terrible objects, or operates in a manner analogous to terror, is a source of the sublime; that is, it is productive of the strongest emotion which the mind is capable of feeling" (39). Like the "sublime object," "homo sacer," often a criminal figure, exists at a distance on the periphery of society. In essence, his presence invokes a sense of social terror needed to maintain order and so remains distanced from the functions of society, much like distance and terror necessitate the sublime experience. The "sublime object" invokes the transcendent through the interplay of pain and pleasure; it provokes pain, but the mind's ability to dominate that terror through reason results in pleasure. "Homo Sacer" reveals the blurred positioning between subject and object much like Addie's function as a "sublime subject" in As I Lay Dying. Agamben writes,

When its borders are blurred, the bare life that dwelt there frees itself in the city and becomes both subject and object of the conflicts of the political order, the one place for both the organization of State power and emancipation from it. Everything happens as if, along with the disciplinary process by which State power makes man as a living being into its own specific object, another process is set in motion that in large measure 
corresponds to the birth of modern democracy, in which man as a living being presents himself no longer as an object but as the subject of political power. (9)

"Homo Sacer" reveals the shift from object to subject that must occur in order for larger ideological structures to function. The constant threat comes from the disciplinary process linked to the law and showcases the shift to the subject. Like the sublime, the tension between pain and pleasure, subject and object reveal larger, transcendent structures of meaning, often masked through the use of language. Like "homo sacer," violence to the body is always implied, but it is the larger ideological (or transcendent) meaning that takes precedence.

Physical violence, and especially pain, provide a complicated ethical problem as it is impossible to convey the feeling of that violence through language. Elaine Scarry points out that pain actually deteriorates language: "[P]hysical pain — unlike any other state of consciousnesshas no referential content. It is not of or for anything. It is precisely because it takes no object that it, more than any other phenomenon, resists objectification in language" (5). For Scarry, pain is essentially passive: "[P]ain only becomes an intentional state once it is brought into relation with the objectifying power of the imagination: through that relation, pain will be transformed from a wholly passive and helpless occurrence into a self-modifying and, when most successful, self-eliminating one" (164). Pain requires a complex relationship with representation, either through language or the imagination. Unlike discussions of power dynamics in issues of subjectivity and identity, pain does not have an object. In some ways, pain and the violence that produces it are purely about the subject who feels and cannot express that feeling. Scarry's discussion suggests that when it comes to pain, intersubjectivity is an impossibility; no amount of verbalization or empathy can make another understand one's pain. But, pain often reflects a moment where physical and ideological violence converge; by 
inflicting pain, the power dynamics of ideology are exposed. Scarry examines political violence related to state authority, especially through torture and war, but much of her discussion of pain can be applied to smaller-scale acts of violence like those that occur in the domestic sphere. In As I Lay Dying, the violence revolves around Addie as subject - either through the violence done to her corpse, the pain inflicted through childbirth, the unbearable life of motherhood, and the pain she, herself, inflicts on children as a teacher. Faulkner represents a multilayered account of violence, both physical and ideological, that reveal the problems of language and the possibility of intersubjectivity.

Addie's narrative passage is the middle of the novel, between the Bundren farm and Jefferson, between life and death, and between mother and (m)Other. For more than half the novel, the reader only sees Addie through the judgmental eyes of others who refuse to engage in acts of empathy because they consistently view the mother, Addie, as an object. It does not matter who Addie is but what she is supposed to be: the perfect, Christian, white, middle-class mother. Addie's physical body, both alive and dead, shows how others refuse her desires and ignore her subjectivity. Addie's maternal body is the Žižekian "sublime object." Her body, which is almost always linked to objects, symbolizes the domestic womanhood and motherhood pervasive in idealized, gendered images reflected through social structures. Addie's thoughts and desires are not revealed until her narrative passage where Faulkner reveals her reflections on her life after her physical death. The placement of Addie's passage after her death shows that even while alive, Addie was always already an object before she becomes a "fetishized corpse" (Slankard 7). The narrative structuring of the text that allows Addie to speak after the death of the physical body suggests that she is a transcendent figure. Faulkner emphasizes that the mother's body is an object of social censure; it functions for society in the same way whether 
alive or a corpse. Once she begins to speak for herself, Addie becomes a "sublime subject." No longer able to consider her a simple object as the community and family do, Addie's subjectivity must be taken into account.

Like "homo sacer," the mother's abject position places her in a situation where she is necessary yet violence to her person can be ignored. As a mother, Addie's body is already unclean or abject, which locates the mother outside of society yet necessary for its survival. In fact, Julia Kristeva begins her analysis of abjection with the language of violence: "There looms, within abjection, one of those violent, dark revolts of being, directed against a threat that seems to emanate from an exorbitant outside or inside, ejected beyond the scope of the possible, the tolerable, the thinkable" (1). As she continues, Kristeva not only relates the abject to the sublime but discusses how fear relates to the mother figure. Kristeva writes, "The abject is edged with the sublime" (11), and she continues, "For the sublime has no object either...The 'sublime' object dissolves in the raptures of a bottomless memory" (12). Kristeva links the complicated problems of language, imagery, and memory to the act of "sublimation," but she also points to a larger problem of the sublime: that, like pain, it has no real object. In fact, she relates the sublime to perception which marks it as subjective (12). Ultimately, the abject and the sublime promote the loss of object that is necessary for transcendence. When it comes to the mother, Kristeva suggests that "Fear of the archaic mothers turns out to be essentially a fear of her generative power" (77). In the language of the sublime, "generative power" suggests the infinite. Women, unlike men, represent the infinite as their bodies are always capable of producing another, an endless familial line. This connection to the infinite suggests that the mother is often not only represented as "abject" but also sublime; however, in Faulkner, sublimity lies not in Addie's object but subject status. 
Unlike the traditional sublime of Edmund Burke and Immanuel Kant, Žižek considers the connections between social discourses and symbolic or sublime objects that represent larger transcendent, ideological structures. For Žižek, the sublime object represents the paradox of symbolic structure often associated as the failure of language in articulations of the sublime by Burke and Kant. Using Jacques Lacan's discussion of subjectivity from a psychoanalytic perspective, Žižek writes of the sublime:

The paradox of the Sublime is as follows: in principle, the gap separating phenomenal, empirical objects of experience from the Thing-in-itself is insurmountable - that is, no empirical object, no representation [Vorstellung] of it can adequately present [darstellen] the Thing (the suprasensible Idea); but the Sublime is an object in which we can experience this very impossibility, this permanent failure of the representation to reach after the Thing. Thus, by means of the very failure of representation, we can have a presentiment of the true dimension of the Thing. This is also why an object evoking in us the feeling of Sublimity gives us simultaneous pleasure and displeasure: it gives us displeasure because of its inadequacy to the Thing-Idea, but precisely through this inadequacy it gives us pleasure by indicating the true, incomparable greatness of the Thing, surpassing every possible phenomenal, empirical experience. (229)

The sublime, which relies on feeling, as Žižek notes, gives pleasure and displeasure through the subject's attempts at understanding the symbolic network. It is a recognition that representation will always fail to accurately convey the Thing or that which it is meant to represent, whether an emotion or an actual object.

Žižek defines the sublime object as a physical object that exists in an in-between position, seen but not seen clearly; similarly, many subjects inhabit in-between positions that promote 
sublime encounters, offering a "sublime subject" as another possible position that exists in between the subject/object discourse of the traditional sublime. As Žižek writes, "The sublime object is an object which cannot be approached too closely: if we get too near it, it loses its sublime features and becomes an ordinary vulgar object—it can persist only in an interspace, in an intermediate state, viewed from a certain perspective, half-seen" (192). The "sublime subject" is a character, a subject, who would traditionally inhabit the position of the "object" in the subject/object dynamic of the traditional sublime. Like the sublime object, the sublime subject shows the interplay between constructed and lived identity categories. Often, the sublime subject inhabits a liminal space, and it is this space that Addie inhabits.

\section{Gender, Faulkner, and Sublimity}

Drawing on a postructuralist (subject/object) approach to literature, Faulkner critics who examine gender often reinforce a subject/object instead of an intersubjective approach to the family. Minrose Gwin endorses the subversive power of the female character in Faulkner, but she still places femininity at odds with masculinity. Gwin suggests that "Faulkner himself, although very much of his culture, becomes in his greatest works the creator of female subjects who, in powerful and creative ways, disrupt and sometimes even destroy patriarchal structures" (4). Gwin invokes Hélène Cixous in her reading of Faulkner and suggests an androgynous or bisexual merger in Faulkner's constructions of creativity: “[I]t denotes an exacerbation of both male and female elements in the self and in writing. Bisexual writing is in a permanent state of tension; it is generated and regenerated by an interaction between the feminine and masculine, between self and other" (10). Although she finds an empowering approach to reading femininity and creativity in Faulkner, Gwin still poses masculine/feminine and self/other as at odds with 
one another in order to create tension. This tension always exists between subject and object, especially in aesthetics as well as discussions of gender.

The same problem of gender and subjectivity related to aesthetics occurs in Deborah Clarke's study of motherhood in Faulkner. For her, the tension in Faulkner lies between masculine creativity and feminine procreativity, which is essentially the same issue that Gwin addresses in proposing a "bisexual" writing. Importantly, Clarke links maternal authority to language and discourse: "[M]aternal authority, especially when aligned with the corporeal body, challenges the dominance of language....When the 'phallic, linguistic symbolic establishment' fails to suppress maternal authority, it reveals the precariousness of its own power and definition" (5). Clarke stresses an interchange between the body and language that exists in the construction of gender, suggesting that Faulkner represents a maternal language linked to the corporeal. Clarke applies this dichotomy to As I Lay Dying, focusing almost exclusively on Addie. In particular, Clarke sees the importance of symbolic objects, like the coffin or the fish, in representing the mother, which implies a word/womb divide throughout the text related to gender (38-39). Clarke's reading of the text emphasizes how Addie's body acts as an object, but it does not give much credence to the possibility of Addie's subjectivity as a mother. My reading of Addie also explores the importance of the corporeal body and draws upon Clarke's examination of her body as a "symbolic object" in order to examine how this object status reveals violence as both physical and ideological.

Barbara Ladd's recent work on gender and authorship in Southern American modernism suggests the intersection between history, gender, and discourses of creativity. Like Gwin, Ladd sees Faulkner's use of a gendered sublime in As I Lay Dying as an issue of authorship. According to Ladd, Faulkner explores a "cultural sublime": "Self-preservation in the face of 
terror is certainly an appropriate form of aggression and may well be the central authorizing scene in and for modernism. It is what is said to authorize public speech. To live to tell the tale of a confrontation with something beyond the bounds of the everyday human world of sociality is to be authorized to tell that tale" (11). Ladd makes a compelling argument for the interaction between the maternal body, speech, and public discourse related to the sublime, but ultimately, the sublimity is Faulkner's more so than Addie's: "Faulkner not only engages in the familiar strategy of demasculinizing the male artist...but gives us two new figures in the scene of the cultural sublime, one a mother-corpse who is a speaker on her own behalf and the other an author whose disembodiment is destabilized" (50-51). Even though she explores the possibility of the mother's speech, Ladd reduces that speech to Faulkner's crisis of authority even while acknowledging the cultural implications of access to public speech. Instead of linking sublimity to Faulkner and the issue of authorship, I suggest a complicated interplay between the rewriting of violence related to the aesthetic sublime through the breakdown of violence related to subject/object and self/other binaries.

In addition to these larger critical works, a number of arguments about the family in As I Lay Dying employ either a Freudian or Lacanian feminist approach, especially in reading the mother. Michael Hardin reads Addie as representing the "death drive," suggesting that "Faulkner provides those with the more dominant sex instincts with the best chance to survive, if not prevail; those characters with dominant death drives are dead, maimed, or incarcerated" (95). According to Hardin, Addie is the family death drive whose sexuality and pleasure only link her to death; whereas, the other characters must confront the death drive through their "sex drive." Like Hardin, Diana York Blaine exclusively associates Addie with death through Kristeva's association of the maternal with abjection, noting that Faulkner "not only stabilizes the maternal 
semiotic irruption but steals sympathy and attention from the Mother even though it is her story that generates the texts just as the text generates her story" (Blaine Para. 8). For Blaine, the maternal body remains abject so that Faulkner can continue writing. Even Marc Hewson, who looks at the importance of Addie's influence on her children, still bases his reading of her on how she functions in relation to the Freudian "death drive"; however, Hewson's perspective of Addie does account for her influence and relationship with her children as didactic. Hewson notes, Addie is an "active force in their [her children's] lives, teaching them (especially the male children who might be more vulnerable) to combat the oppressive and ultimately negative philosophy of the patriarchy in the book" (551). Hewson reads As I Lay Dying as reversing the polarities of the "death drive" into inertia for life, but in order to make this argument, the mother must still inhabit the position of Freudian maternal object (554). All of these approaches to As $I$ Lay Dying explore the Freudian "death drive," but at the same time, that "death drive" is only linked to the mother figure, Addie. The objectification of Addie's living and dead body represents a merger with the maternal body for the other characters in the text. In reality, the novel shows the ideological construction of the family related through the physical and ideological body of the mother. The text is rarely about Addie but more of what she represents. Like the Oedipal configuration, the mother must function as "object" or "other" in order for her children and husband to explore their own subjectivities.

\section{The Violated Corpse: Violence and the Corporeal Body}

In the novel, Addie's corpse is threatened with and subjected to multiple violent acts: holes drilled into her face through the coffin lid, decay through long travel, drowning in a river, and almost incineration by fire. All of these acts, whether intentional or unintentional, are committed by the social unit meant to protect rather than harm one another: the family. Even 
Vardaman connects the violence he enacts on a fish to the death of his mother. In particular, the men in the family, including the more intuitive Darl, commit all of these aggressively violent acts. Ultimately, these violent physical acts applied to a corpse reflect the psychological and ideological violence performed on the mother in a patriarchal society. Like homo sacer, the abject status of the mother's body justifies individual acts of violence without removing its ideological import. Faulkner implies that the communal validation of these individual acts actually transcends the taboo nature of her body. In essence, the cleansing nature of sacrifice is still performed even without explicit communal participation. These violent acts make both the Bundren family and the community address the conflict between Addie's body and the ideological images of her as mother.

After prolonged descriptions of Addie's deathbed and dying, Cash constructs a coffin under Addie's very watchful eye; however, with the completion of the coffin, Vardaman, a young, boy, drills holes into the lid, marking the first instance of corporeal violence in the novel. Vardaman equates Addie's death with his own killing of a fish, leading to his proclamation: "My mother is a fish" (Faulkner 514). The fact that many of the characters substitute objects for Addie's corporeal and ideological body suggests that the mother is a "sublime object" representative of larger transcendent ideas. According to Žižek, the "sublime object" has an ideological function, especially in political ideologies. For instance, a figure like a "king" assumes a transcendent position that validates patriotism, nationalism, or imperialism. The king is an objective figure who stands in for a transcendent political or military structure. The mother functions in a similar manner; she is a figure who stands in for a larger ideological idea that reinforces the importance of maintaining the family unit. Faulkner reinforces this connection through Peabody's assessment of the link between death, the body, the mind, and grief: "I can 
remember how when I was young I believed death to be a phenomenon of the body; now I know it to be merely a function of the mind-and that of the minds of the ones who suffer the bereavement. The nihilists say it is the end; the fundamentalists, the beginning; when in reality it is no more than a single tenant or family moving out of a tenement or a town" (Faulkner 29). Death is a function of the mind or the construction of ideology. In the case of Addie, through grief, the characters reconstruct their mother in their minds, and those reconstructions are often influenced by what a mother should be. In addition, Faulkner links death and the body specifically to the town. Addie's dead body is the corporeal signifier of the ideology of motherhood and the violence it enacts on the subject. The fact that much of the violence to Addie's body occurs before her section of the novel suggests that the violence her body bears in death eventually reveals the ideological violence done to her as she fulfills her expected role as mother.

The link between corporeal and ideological violence is first established when Vardaman drills the holes in his mother's coffin so that she can breathe. Although he attempts to help his mother through his limited understanding of his grief and his feeling of responsibility for her death, Vardaman's solution ultimately results in a violent disfiguration of his mother's body. Vernon Tull relates finding Vardaman beside the coffin: "And the next morning they found him in his shirt tail, laying asleep on the floor like a felled steer, and the top of the box bored clean full of holes and Cash's new auger broke off in the last one. When they taken the lid off they found that two of them had bored on into her face" (Faulkner 48). Here, in the ultimate violence he enacts on her face, Vardaman shows his violent reaction to his mother's death. Vernon Tull's next section in the novel reveals the gendered ideology related to Addie's body. Addie is placed in the coffin "head to foot so it wouldn't crush her dress" (Faulkner 56). Tull then continues, "It 
was her wedding dress and it had a flare-out bottom, and they had laid her head to foot in it so the dress could spread out, and they had made her a veil out of a mosquito bar so the auger holes in her face wouldn't show" (Faulkner 56-57). Vardaman disfigures Addie's face, but to cover up the violence, the family places their mother in her wedding dress, cementing her as ideological wife and mother. Addie's expected familial role covers up the corporeal violence enacted on her corpse.

The violence to Addie's corpse continues as she travels from the farm to Jefferson. At the river ford, the entire family drowns Addie's corpse; however, Anse insists on crossing the ford. In their attempts to help Addie cross the river, her sons ultimately end up drowning her corpse. Darl describes the violent and ominous nature of the river: "Before us the thick dark current runs. It talks up to us in a murmur become ceaseless and myriad, the yellow surface dimpled monstrously into fading swirls travelling along the surface for an instant, silent, impermanent and profoundly significant, as though just beneath the surface something huge and alive waked for a moment of lazy alertness out of and into light slumber again” (Faulkner 93). Of course, in trying to cross the ford, a tree dislodges the wagon, the mules, and the coffin. And yet, despite all of this, Addie's coffin survives. In his next section, Darl remarks:

We return to the river. The wagon is hauled clear, the wheels chocked (carefully: we all helped; it is as though upon the shabby, familiar, inert shape of the wagon there lingered somehow, latent yet still immediate, that violence which had slain the mules that drew it not an hour since) above the edge of the flood. In the wagon bed it [the coffin] lies profoundly, the long pale planks hushed a little with wetting yet still yellow, like gold seen through water, save for two long muddy smears. (Faulkner 105) 
The violence of the river lingers in the image of the wagon, and yet, Addie survives with little damage. Marianne de Koven notes in her study of modernism and gender related to water imagery: "It is important that this threatening desire, gendered female, is imagined as a turbulent flood, either of water as a general element or, more specifically, as unleashed red flood of all the dangerous, repressed sexual-political matter...this is simultaneously the red flood of socialist revolution and of menstruation and childbirth" (34). Although social revolution is less an issue in Faulkner, De Koven uses Luce Irigaray to point to the fact that water in modernism represents a link between the maternal body and water imagery. Addie must survive her drowning in the river, because by placing her in water, she merges with a symbolic representation of the mother's body; however, the violence of that immersion reveals her objectified status in her family. Despite her trial by water, Addie is vindicated, suggesting that the mother survives despite the continual violence done to her body.

Darl attempts the final violent act upon Addie's corporeal body; however, that act is prompted by an attempt to help Addie. Like Vardaman, who tries to let Addie breathe, and Anse, who tries to meet Addie's wishes, Darl's violent act tries to relieve Addie's body from communal spectacle and ridicule. Stopping at a town in route to Jefferson, Moseley, a pharmacist, relates the stinking odor of Addie's decaying corpse: "He [Albert, an acquaintance of Moseley's] said the wagon was stopped in front of Grummet's hardware store, with the ladies all scattering up and down the street with handkerchiefs to their noses" (Faulkner 136). After relating Anse's dispute with the town marshal about public health, Moseley relates: "It had been dead eight days, Albert said....It must have been like a piece of rotten cheese coming into an anthill" (Faulkner 136). Addie's corpse as well as her family create a communal spectacle that 
results in social censure. After this embarrassment of Addie, Darl decides to set fire to Gillespie's barn. Cash's perspective reveals Darl's motives:

But I [Cash] thought more than once before we crossed the river and after, how it would be God's blessing if He did take her outen our hands and get shut of her in some clean way, and it seemed to me that when Jewel worked so to get her outen the river, he was going against God in a way, and then when Darl seen that it looked like one of us would have to do something, I can almost believe he done right in a way" (Faulkner 157).

Cash agrees with Darl's decision to try to save Addie from the spectacle her corpse creates. Addie's death and her smell draw attention to the mother's body, insisting on its recognition.

The violence enacted on Addie's body suggests that confrontation with the corporeal body is part of Addie's revenge upon her family for her entrapment as a mother. In her section, Addie takes revenge on her family by making them take her body to Jefferson and as a result, they must confront her ideological position as mother. ${ }^{1}$ Addie sets this up as a conflict between language (reflecting ideology) and the mother's corporeal body, tricked into a second pregnancy: "It was as though he had tricked me, hidden within a word like within a paper screen and struck me in the back through it. But then I realized that I had been tricked by words older than Anse or love, and that the same word had tricked Anse too, and that my revenge would be that he would never know I was taking revenge" (AILD 116). Addie decides to take her revenge, but her passage is unclear as to whether that revenge will be exacted on Anse or language. As the last line of the above passage suggests, Anse would be unaware of Addie's revenge. After the line about taking her revenge, Addie continues, "And when Darl was born I asked Anse to promise to take me back to Jefferson when I died, because I knew that father had been right, even when he couldn't have known he was right anymore than I could have known I was wrong" (AILD 116). 
By insisting on being buried in Jefferson, Addie exacts her revenge on the community and society that dictated the gendered roles she was supposed to fulfill. Her punishment is not solely intended for her family. It would be easy to read Addie's revenge as her affair with Whitfield, but the construction of this passage shows that Addie connects that revenge with her decision to be buried in Jefferson, separating herself from her family and community. As her dead body is carted throughout the community, the people must confront the actual, dead body or object that was already objectified through words and things throughout life.

By making the dead body a mother's body, Faulkner emphasizes the mother's abject status. Even in death, Addie's body demands to be recognized. Her smell draws attention to the physical body that must be sacrificed in order for the ideological body to survive. Addie has been killed but she cannot be sacrificed; if she is sacrificed, the community must confront the desiring mother, who would rupture the ideological fiction of sacrifice. Since the mother is socially "unclean," Addie represents a "sacred life," preserved despite killing as it serves to reinforce ideological constructions of white, middle-class motherhood. As Agamben writes, "Life that cannot be sacrificed and yet may be killed is sacred life" (82). The expulsion of Addie's body from the town and Darl's insistence on destroying her corpse show society's marginalization and objectification of the mother. When confronted with her body and her desires, society must abject the mother's corporeal body, the body that bears children. As a result, Addie's dead body is a loaded Žižekian "sublime object" that reflects her abject status, but once she tells her story, Addie's subjectivity must be acknowledged, making her a "sublime subject." 


\section{Competing Mothers: Addie Bundren versus Cora Tull}

Addie Bundren is the "fetishized corpse" (Slankard 7), the separated mother's body that is the "price of admission into patriarchal culture" (Fowler 8), and "the maternal corpse" replacing "maternal absence" (Clarke 35). Despite death, Amy Louis Wood, Doreen Fowler, Karen R. Sass, and almost every other critic who has written on gender in As I Lay Dying insist that Addie is the central focus of the novel. ${ }^{2}$ The placement of Addie's monologue in the center of the novel as well as the journey to Jefferson that occurs as a result of her dead body certainly point to her importance. Deborah Clarke, Marc Hewson, and Paul S. Nielsen focus specifically on the interplay of language and speaking in the novel through Addie's short passage. ${ }^{3}$ In particular, these critics see Addie's perspective as the key to understanding the rest of the characters in the text, including her children, her husband, and the community that surrounds them all. ${ }^{4}$

Even though Darl opens the novel, the Bundrens' neighbor, Cora Tull, gives the first image of the dying Addie Bundren amidst a conversation about baking cakes. Like Darl's description of the farm in his opening passage, Cora uses realism to describe Addie: "The quilt is drawn up to her chin, hot as it is, with only her two hands and her face outside. She is propped on the pillow, with her head raised so she can see out the window, and we can hear him every time he takes up the adze or the saw" (AILD 6). At the end of this passage, the objective tone shifts to the subjective as Cora includes herself in the story by using the pronoun "we." The passage then shifts between a realist and stream-of-consciousness mode as Cora casts her judgments on Addie: "If we were deaf we could almost watch her face and hear him, see him. Her face is wasted away so that the bones draw just under the skin in white lines. Her eyes are like two candles when you watch them gutter down into the sockets of iron candle-sticks. But 
the eternal and the everlasting salvation and grace is not upon her" (AILD 6). Cora's description is tinged with unreliability. She (along with the reader or "you") watches Addie in order to judge salvation or transcendence.

Cora expects Addie's dying body to represent the transcendent grace of Christian ideology through salvation; she never conceives of transcendence outside of a God figure. In tracing the strain of ambivalence in the sacred, Agamben notes that ambivalence about the sacred arises when sociological and anthropological work moves from the primitive to biblical religion (75). A marker of ambivalence about the sacred occurs at the end of the nineteenth and beginning of the twentieth century, the period that marks modernism. As Freud goes on to discuss the "taboo," the sacred becomes ambiguous as it "excludes in including" (Agamben 77). Cora's adamant Christian ideology, especially related to motherhood, juxtaposed against Addie's more secular attitude reveals Addie's ambivalent position. Her ambiguity reveals her position as "mater sacer." Her ambivalence about motherhood shows the ambiguous nature of the sacred. The sacred object is excluded due to her perceived failures at mothering but included and necessary for the communal voice in the novel. Addie's ambivalence about mothering makes her ripe for social sacrifice. As her passage will later show, Addie feels a secular grace that exists beyond patriarchal languages, like Christianity, that judge through doctrine rather than using empathy. Addie's grace also makes her a sacred object as she clearly connects with the transcendent regardless of its lack of religious nature. Cora represents the connection between Evangelical Christianity and constructions of motherhood. ${ }^{5}$ Faulkner subverts the Biblical maxim: "In the beginning was the word." In fact, from the beginning was the mother, not the word. 
As she lays dying, Addie is under the scrutinizing eyes of her family and neighbors whose internal thoughts are known through Faulkner's stream-of-consciousness passages. Tamara Slankard suggests that the Bundrens are "pathologically 'other.' Communicating only through individual monologues, they are unable to fully articulate and differentiate self from other, and they are able to negotiate through both the rural and urban terrains of the South only with the greatest of difficulties" (10). Slankard suggests that the self/other or subject/object binary collapses in Faulkner's text, but throughout much of the novel, Addie is the ultimate object. Like the corpse she eventually becomes, Addie as a mother is already an object in the text. By allowing the reader to access Addie's own desires and thoughts, Faulkner makes it apparent that Addie is in fact a subject regardless of her object status to the rest of the characters in the novel.

Addie as subject is lost in the objectifying idealizations of white, middle-class motherhood despite her low-class status. Cora's commentary focuses on how Addie fails to live up to Cora's Christian notions of what a proper wife and mother should be. By choosing to marry Anse, Addie's life diverges from her middle-class upbringing in Jefferson; however, despite the change in her class position, the working and lower-class woman is still expected to live up to middle class norms of late nineteenth century femininity. Because of her lack of money and independence, Addie finds middle-class expectations of motherhood in working or low-class economic situation stifling. As many of the characters in the community, like Vernon Tull, remark, women like Addie are expected to work hard: "It's a hard life on women, for a fact. Some women....Worked every day, rain or shine; never a sick day since her last chap was born until one day she kind of looked around her and...laid down on the bed and pulled the covers up and shut her eyes" (Faulkner 20). Cora Tull is the only female voice from the community, and 
due to her investment in white, middle-class Christian norms regarding mothers and wives, she is Addie's harshest critic. When Addie refuses to be buried near the farm in favor of Jefferson, Cora views a woman's body, living or dead, as belonging to her family: “A woman's place is with her husband and children, alive or dead" (AILD 16). Cora then compares her position as wife and mother with Addie's: "I have tried to live right in the sight of God and man, for the honor and comfort of my Christian husband and the love and respect of my Christian children. So that when I lay me down in the consciousness of my duty and reward I will be surrounded by loving faces, carrying the farewell kiss of each of my loved ones into my reward" (AILD 16). Cora believes she fulfills her "duty" in the eyes of God and man. By showing Cora's harsh judgment of Addie, Faulkner makes the ridiculousness of her perspective apparent; he shows the constructed and constricting nature of gendered family roles, especially those endorsed by society or the community.

Darl and Cora are the only two characters who directly comment on Addie's mothering at length, showing both the family and the community's perception of Addie as a mother. In his reading of the novel, Marc Hewson separates the Bundren children as belonging to either Anse or Addie. According to Hewson, Darl is one of Addie's children, because he uses her way of communicating through intuition and emotion as a refusal of Anse's patriarchal power and language (561). Although he may speak (or more aptly fails to speak) his mother's language, Darl recognizes how Addie's mothering of Jewel differs from that of her other children and intuits that Jewel is not Anse's son. Darl may inherit his mother's way of understanding and communicating, but he also recognizes the emotional distance created by intuition. When it becomes apparent that neither Anse, Darl, nor Jewel will return before Addie dies, Darl says a wordless goodbye to his mother. This goodbye scene is conveyed to the reader through Cora's 
(an outsider's) perspective; it is Cora who plays the role of author and "writes" Darl's emotional response: "It was Darl. He come to the door and stood there, looking at his dying mother. He just looked at her, and I felt the bounteous love of the Lord again and His mercy. I saw that with Jewel she had just been pretending, but that it was between her and Darl that the understanding and true love was" (AILD 17). Cora reads this moment as an intersubjective moment beyond language, a sublime moment. Cora plays the role of "subject" or author in the traditional sublime dynamic, making Darl and Addie "sublime objects." Cora creates this transcendent scene through the "bounteous love" of the Lord. She becomes the figure that mediates sublimity and turns it into a confirmation of Christian ideology. Both Addie and Darl function as objects under her gaze who confirm her own ego-driven concept of transcendence, an affirmation of her beliefs about mother and child. The feelings and emotions of Addie and Darl are removed from the text. Access to their experience is given only through Cora's untrustworthy gaze, which reflects society's disruption of the real emotional power of intersubjective connection.

Cora's reading of the previous scene also introduces the tension between Jewel and the rest of the Bundren children. From Cora and Darl's perspective, Jewel is the favored child. Cora sees Darl as Addie's true child as he identifies and connects with her in the wordless goodbye; however, as the reader later learns, Darl's perspective on Addie's relationship with Jewel is quite different. Darl intuits not only Addie's preference for Jewel but also the reasons behind her preference. He details how Addie, believing Jewel to be sick, has her other children perform Jewel's chores as he selfishly sneaks out at night (AILD 84). Darl notices the relationship between Jewel and his mother through chores, but Darl's revelations connect Addie's preference of Jewel to Cora's earlier remarks about Addie's coddling of Jewel (AILD 15). Once she discovers Jewel's deceit and betrayal, Addie is distraught: "That night I found ma sitting beside 
the bed where he was sleeping, in the dark. She cried hard, maybe because she had to cry so quiet; maybe because she felt the same way about tears she did about deceit, hating herself for doing it, hating him because she had to" (AILD 88-89). Once he sees his mother crying, Darl remarks, "And then I knew that I knew. I knew that as plain on that day as I knew about Dewey Dell on that day" (AILD 89). Without direct communication or language, Darl intuits Addie's secret: the affair with Whitfield that leads to Jewel. Linking Addie to Dewey Dell, sex, pregnancy, and eventual motherhood are the central secrets of the text.

Rather than reading Darl as a feminine figure who connects with the maternal, Darl empathizes and imagines the trouble connected with femininity and maternity. Although he understands Addie and Dewey Dell's desires, Darl is part of the mechanism in the text that shows how others judge and perceive feminine desire. Later in the text, Darl's attempt to burn Addie's coffin and his threatening behavior towards Dewey Dell's desire for an abortion show that he is perhaps not as sympathetic or empathetic as he is earlier in the text. Darl's shifting empathy throughout the novel positions him as an outsider not only to the community but also to the family itself. His ability to intuit his family secrets only creates tension between himself and the other members in his family. By knowing different truths about his family members, Darl is in the position to empathize; however, more often than not, his intuition threatens. As he is rejected by not only the men but also the women in the text, Darl's intuition and empathy are threatening forces that must be controlled. Due to his intuition, a trait typically associated with the feminine in patriarchal ideologies, Darl is pushed further away from both his family and his community. In the end, Darl's empathy leads to his institutionalization. In essence, Darl feels empathy in its purest form — as an act that leads to the dismantling of his own subjectivity. While he promotes empathy, Faulkner also suggests that it can be a dangerous act when the 
boundaries of the self become too porous. Faulkner uses Darl to both promote and warn about the power of empathy.

As the novel leads into Addie's passage that conveys her relationship to her husband and children, Cora narrates another passage directly preceding Addie's "confession" of her sins. Again, Cora upholds traditional norms of femininity through Christian morals. Cora relates those norms through direct connection to maternity; she tells Addie, "God gave you children to comfort your hard human lot and for a token of His own suffering and love, for in love you conceived and bore them" (AILD 112). Ironically, Addie connects her "lot" to punishment by responding, "My daily life is an acknowledgment and expiation of my sin" (AILD 112). Addie refers to her infidelity to Anse; whereas, Cora only sees Addie's sin as favoritism toward Jewel: "When the only sin she ever committed was being partial to Jewel that never loved her and was its own punishment....There is your sin and your punishment too. Jewel is your punishment" (AILD 113). Addie refuses the salvation offered to her through God's son, Jesus, in preference for her own biological son, Jewel: "He is my cross and he will be my salvation. He will save me from the water and from the fire. Even though I have laid down my life, he will save me" (AILD 113). Although it is easy to misread his use of biblical language, Faulkner subverts the transcendent paradigm of father and son reaffirmed by language. The "he" Addie refers to is Jewel, and through foreshadowing, Faulkner reveals the son who saves Addie's corpse from the river (or water) and the burning barn (or fire). Despite the censure of the community, Addie believes that her mothering will lead Jewel to save her, if not love her, after her death.

For more than half of the novel, the reader only sees Addie through the judgmental eyes of others who refuse to engage in acts of empathy by consistently viewing the mother as an object. It does not matter who Addie is but what she is supposed to be: the perfect, Christian, 
white, middle-class mother. Addie's physical body, both alive and dead, shows how others refuse her desires and ignore her subjectivity, and this is metaphorically shown through the violence in the text. Once she begins to speak for herself, Addie becomes a "sublime subject." No longer able to consider her a simple object as the community and family do, Addie's subjectivity must be accounted. Addie's thoughts reveal how society's rules prevent her from connecting with other characters. The construction of society prevents Addie's transcendence from becoming reciprocal. By showing a link between the sublime and the failure of language, Addie's passage represents a rewriting of the Romantic tradition that linked authorship and language. By denying Addie any moment of empathetic sublimity with any other character in the text, Faulkner shows the reader that subject/object approaches to human relationships only end in death. An object is never allowed any subjectivity in life.

Addie's passage suggests a connection between being alive and being dead that does not see either position as mutually exclusive. Paul S. Nielsen reads Addie or Addie's passage in As I Lay Dying as the fulfillment of the dictum given to her by her own father: "the reason for living was to get ready to stay dead a long time" (AILD 114). Nielsen addresses this in terms of the conflict between language and meaning or word and deed for Addie: "[L]ife is a struggle with the words as much as with the deeds, and in the telling of the struggle is to make the word full of meaning, to make the word one with the deed" (34). Nielsen suggests that Addie's struggle with words is a struggle between life and death; however, Addie only addresses life after death, blurring the boundaries between the two states of being. Critics have focused extensively on Addie as a dead object or body related to maternity. ${ }^{6}$ Although she speaks in death, Addie's passage is about life and birth specifically. Addie draws a parallel between generation through 
childbirth and sexual desire. The socially imposed role that values women for only their procreative values strongly connects them to both life and death.

A cursory reading of Addie's mothering might suggest that she is a "bad" mother, especially if too much attention is paid to Cora Tull's harsh judgments, but her passage expresses the connections between language, patriarchal expectations, and motherhood. For Addie, life before motherhood was terrible, because it was dead:

So I took Anse. And when I knew that I had Cash, I knew that living was terrible and that this was the answer to it. That was when I learned that words are no good; that words don't ever fit even what they are trying to say at. When he was born I knew that motherhood was invented by someone who had to have a word for it because the ones that had the children didn't care whether there was a word for it or not. (AILD 115)

Although she does not explicitly depict the moment of childbirth, for Addie, childbirth and the resulting motherhood give her access to a personal sublimity. Exposed to the terrifying and life threatening experience of childbirth, Addie's sublime moment reveals the failure of language to express motherhood and its transcendence. "Motherhood," the word, represents a fixed set of social expectations; whereas, real motherhood is felt through connection and exists beyond language.

After she discusses becoming a mother, Addie analyzes her relationship with Anse as a result of her sublime realization that parenthood creates human connection that exists outside of language. Addie connects Anse to the failure of language as he uses words that disagree with his actions. In particular, Addie focuses on Anse's use of the word "love." Faulkner depicts "love" as a socially constructed concept that reinforces traditional gender roles through its endorsement of heteronormative marriage. As Addie notes, "He [Anse] had a word, too. Love, he called it. 
But I had been used to words for a long time. I knew that that word was like the others: just a shape to fill a lack...Cash did not need to say it to me nor I to him, and I would say, Let Anse use it, if he wants to. So that it was Anse or love; love or Anse: it didn't matter" (AILD 116). Words are meant to fill a lack, which in Addie's case, suggests the inability of language to express human emotion. Luce Irigaray has examined how language is patriarchal, using a signifier to replace a signified, ignoring other ways of thinking, knowing, speaking or writing that avoid "masculine" or "patriarchal" logic. ${ }^{7}$ Lacanian psychoanalytic approaches to Addie examine her use of the word "lack" to express the disconnection between signifier and signified related to gender. ${ }^{8}$ Unlike the use of language, which fills a lack, Addie uses emotion as a way of expressing oneself through eventual actions. Although the passage points to the Derridean idea that there is no essence behind a word as they are all random signifiers of objects, especially as "Anse" and "love" are interchangeable, Addie does not point to language itself but to the power structures that use language as an ideological violence to others. Ironically, Addie does not judge Anse for his use of language even though many characters spend most of the text judging her. She recognizes that Anse has learned to use language as a tool of control even if it is a flawed way to create human connection. Anse distances himself from connectivity that Addie feels through the rearing of a child. Addie understands that Anse prefers to use language as a substitute for emotion, and if it is what makes him comfortable, he should continue to use it.

Addie also realizes that her sublime moment related to motherhood would not be possible without Anse, and she sees him as part of the violation that made her less alone. Addie writes, “Anse or love: it didn't matter. My aloneness had been violated and then made whole again by the violation: time, Anse, love, what you will, outside the circle" (AILD 116). Through the creation of family, Addie finds her aloneness violated, but she does not necessarily find this 
violation negative. Addie's negativity does not appear until she gives birth to her second child, as she becomes locked into the role of mother and procreator. As a mother to a single child, Addie briefly escapes the "aloneness" of life that ends in death. With a second child, Addie finds the social constraints and expectations of motherhood as interfering with human connection.

Addie associates both motherhood and fatherhood with that "jar" or empty space filled through the production of children. Like Anse, Addie sees her own body as an emptiness or a lack (like the empty jar or vessel) ${ }^{9}$ : "I would think: The shape of my body where I used to be a virgin is in the shape of a and I couldn't think Anse, couldn't remember Anse. It was not that I could think of myself as no longer unvirgin, because I was three now" (AILD 117). The empty space in Addie's text aligns with her refusal to use language to express emotion or feeling. Addie reverses society's expectations of women by associating virginity with emptiness rather than meaning (like purity or innocence) while connecting the "unvirgin" with fullness not named. Like the jar, the space in the text must be filled in order to reveal the meaninglessness of language. Naming her children Darl or Cash did not matter, because the names do not adequately express the experience of childbirth or motherhood, of becoming "unvirgin." Also, the name does not express the social expectations placed on women that revolve around her position as procreator or a body that is filled with children rather than language. ${ }^{10}$ Addie sees the emptiness of language, because her body mirrors that emptiness. Her body becomes the communal body that fills the lack of language both before and after her death; the maternal body is the object most harshly judged by the community.

In her passage, Addie shows how Cora criticizes her after maternity has made her body an object of social spectacle, fulfilling the transcendent role of "sublime object." Forcing the 
reader to reread Cora's harsh judgments, Addie becomes a "sublime subject" as s/he is forced to confront her subjectivity. Addie writes, "And so when Cora Tull would tell me I was not a true mother, I would think how words go straight up in a thin line, quick and harmless, and how terribly doing goes along the earth, clinging to it, so that after a while the two lines are too far apart for the same person to straddle from one to the other" (AILD 117). Using the image of the line, Addie expresses how those who conform to language and socially expected roles are unable to imagine her position until they "forget the words" used to judge others (AILD 117). The two lines can never intersect, showing that human connection is harder to accomplish as the distance between lived experiences and socially expected roles diverges. Language creates distance, especially emotional distance between two people as family members should "love" one another.

Addie introduces the social pressures of maternity through Cora but then moves to Anse's expectations of her duty as wife and mother as the producer of more children. Again, Addie connects her relationships within her family to the problem of language. Addie remarks, "I gave Anse the children. I did not ask for them. I did not even ask him for what he could have given me: not Anse. That was my duty to him, to not ask that, that duty I fulfilled. I would be I; I would let him be the shape and echo of his word. That was more than he asked, because he could not have asked for that and been Anse, using himself so with a word" (AILD 117). Addie locates the difficulties of marriage in the problems of language and communication. Through Addie, Faulkner points to the difficulties of transcendence related to the limitations of language; he shows how language has been employed to limit the options of both women and men. Like Addie, Anse is a disempowered figure. Addie has insight into her role as mother and woman. She also has insight into Anse's expected role as father and man related through the laws of language and systems of power. As Addie says, "And then he died. He did not know he was 
dead" (AILD 117). Although the reader can identify with Addie's anger, Anse is pitiable, because he does not become aware of how society dictates his position and subjectivity. Anse is the ideal modern subject, because he cannot see outside of the ideological systems in which he participates. Conversely, Addie is closer to a postmodern subject as she knows her part in the reiteration of ideological structures even if she continues to participate in them anyway. Faulkner points to how gender and sexuality are constructed; modernism is the moment where social constructions breach traditional representation through stream-of-consciousness form.

In order to contrast her relationship with Anse, Addie gives the details of her affair with Whitfield; however, she speaks of the affair in the same terms as her marriage — as a system of credits and debits related to the production of children. Despite this capitalist image, Addie views her reproductive role as a part of infinity, a trope of the sublime: "But for me it was not over. I mean, over in the sense of beginning and ending, because to me there was no beginning nor ending to anything then...My children were of me alone, of the wild blood boiling along the earth, of me and of all that lived; of none and of all" (AILD 118). Childbirth reveals the terror of being locked into motherhood and infinity through constant reproduction of life. In contrast to life, Addie also notices that life begets death, another form of infinity. To Addie, life and death represent transcendence as they defy the confines of language. Still, Addie tries to use reason to overcome the sublimity of childbearing, especially as she bears Jewel, the child from her affair. Like the Kantian sublime, reason interferes in Addie's understanding of infinity, and she begins to quantify her children like an empirical accounting of mothering and desire. Addie writes that she "gave Anse Dewey Dell to negative Jewel. Then I gave him Vardaman to replace the child I had robbed him of. And now he has three children that are his and not mine" (AILD 119). Addie equates the accounting of children with the domestic, suggesting that her children after Jewel 
was her way of living so she could get "ready to stay dead" (AILD 118). For Addie, this process of child production is related to the domestic or the house: "a man cannot know anything about cleaning up the house afterward. And so I have cleaned my house" (AILD 118). Addie must "clean up her house" in order to make up for her sin and her desire that occurred in the woods outside of the domestic home. Her womb, like her house, has been cleaned by making more children in order to honor her duty to Anse, her husband. Overall, Addie shows motherhood as a system of violation and violence that results in childbirth, a violent yet natural experience.

\section{Mater Sacer or the Violent Mother: Addie's Child Abuse and Dewey Dell's Abortion}

Addie emerges as a "sublime subject" in her passage in the novel; however, one of the ways that Faulkner reveals that subjectivity to the reader is through her comments that refute her ideological role as mother, wife, and teacher. Faulkner points to her extramarital affair with Whitfield as a way of defying her role as wife and mother, but her acts as a teacher reflect an early defiance against gendered ideology that expects women to be nurturers. Addie's own acts of violence are depicted as extreme acts of empathy, but ultimately, she deconstructs the gendered expectations of women as related to children. Addie participates in child abuse, even before she marries Anse and by doing so, reflects an anti-maternal attitude when compared to ideological expectations of mothers in a patriarchal society. By including this scene, Faulkner draws a parallel between the female teacher and the mother-both of whom are expected to be nurturing figures. By participating in violent acts, Addie reveals her subjectivity through her section, and through this revelation, she gives voice to the strictures of maternity constructed by society. By focusing her violence toward children, Addie defies the nurturing nature expected of women and especially mothers. Through this act of rebellion, Addie shows an attitude towards children that is unacceptable by social standards. Addie reveals herself as "mater sacer," an 
abject life due to her failure to conform to expected maternal roles. She is also a sacred life that is necessary to relieve the community of their burdens. Addie exposes herself to the censure of the community and her death is the sacrifice necessary to bring the communal voices together.

Once exposed to her feelings in her passage, Addie also constructs her own subjectivity through violence she employs and feels. Addie describes her anger and hatred of her pupils, suggesting an ideologically anti-maternal attitude. For Addie, the everyday routine of the classroom, like the modern machine, represents the obliviousness of the modern subject's existence. Addie focuses on the failure of her pupils to connect with each other and with her: "And when I would have to look at them day after day, each with his and her secret and selfish thought, and blood strange to each other blood and strange to mine" (AILD 114). Addie's thoughts on her pupils mimics the structure of the novel as each character expresses "his and her secret and selfish thought." From the beginning of Addie's passage, the failure of the modern subject is the failure of language to express emotion. As Paul S. Nielsen notes, Addie believes in speaking through action or "deeds" rather than language or "words." The importance of action becomes clear as Addie punishes her students through whipping: "When the switch fell I could feel it upon my flesh; when it welted and ridged it was my blood that ran, and I would think with each blow of the switch: Now you are aware of me! Now I am something in your secret and selfish life, who have marked your blood with my own for ever and ever" (AILD 114). Through violence, Addie conveys a feeling of empathy, imagining the pain of another. Addie feels the switch and the blood. Addie's comments about maternity and sexuality reflect the failure of language, and by engaging in violence herself, she stresses the inability of language to communicate ideological violence. As Elaine Scarry argues, there is no way to communicate pain; it always points to the fact that language is inadequate. Knowing the ineffectiveness of 
language, Addie chooses violence as a form of communication. By communicating pain through pain (as in violence), Addie avoids the barriers created by language. Through the use of pain, Addie commits the ultimate act of empathy that avoids the vague representational problems of language. The violence makes her pupils aware of her, but it also gives her self-awareness. It allows her to feel that she is something other than a dead object.

As the passage continues, Addie makes it clear that motherhood gives her access to empathy, because it is a violent act. She discusses motherhood in terms of blood, a representative of the abject mother's body. Her description of blood related to motherhood parallels the blood she draws from her pupils. Blood links her to children. Addie says,

I knew that is had been, not that they [her students] had dirty noses, but that we had had to use one another by words like spiders dangling by their mouths from a beam, swinging and twisting and never touching, and that only through the blows of the switch could my blood and their blood flow as one stream. I knew that it had been, not that my aloneness had to be violated over and over each day, but that it had never been violated until Cash came. Not even by Anse in the nights. (AILD 115-116)

After childbirth, Addie reflects on her interactions with her students, who are children not her own. Addie notes that the distance created between herself and her pupils (which she perceives as loneliness) is created through the use of language that fails to express experience, emotion, and individual subjectivity. Addie's use of the term "violation" to describe her aloneness could be misread as an example of her "bad" mothering, because it could be read as a complaint. However, her use of the term "violation" has a connotation that implies sexual violence produces the child. It is through the violence of sexuality that her first child violates her aloneness. The violence of the word "violation" suggests a negative perspective, but Addie goes on to reveal 
motherhood as a relief from her loneliness. The passage connects violence to maternity and both lead to empathy. Faulkner constantly points to violence as the source of the necessity for empathy.

Despite all of the events that lead to the final burial of Addie's body, the novel ends with life or Dewey Dell's pregnancy (even if it is a child she does not want). Comparing her position with that of her mother, Dewey Dell reveals that what she wants to abort is not so much the physical baby as the social expectations surrounding motherhood. In her attempts to buy an abortifacient from Moseley, Dewey Dell appears to be an uneducated, country bumpkin, and when she asks for help for the "female trouble," Moseley believes her issue is menstruation. As their conversation continues, the issue is about the presence or absence of blood (Addie's signifier for maternity): "That's it. It's [the blood] already stopped" (AILD 135). Once he understands what Dewey Dell wants, Moseley immediately refuses and advises Dewey Dell to get married, to fulfill her role as not only mother but proper wife: "Well, I haven't got anything in my store you want to buy...unless it's a nipple. And I'd advise you to buy that and go back home and tell your pa, if you have one, and let him make somebody buy you a wedding license" (AILD 135). Dewey Dell does not seem to understand his advice; her ignorance about the process of abortion becomes apparent. Again, Moseley offers Dewey Dell the same advice: "You get that notion out of your head, The Lord gave you what you have, even if He did use the devil to do it; you let Him take it away from you if it's His will to do so. You go on back to Lafe and you and him take that ten dollars and get married with it" (AILD 136). The proper way to deal with pregnancy is through marriage; however, Dewey Dell's need to abort her baby is not so much from shame but from the limitations of motherhood. Like her mother, Dewey Dell reveals 
her distrust of maternity through the violence she intends to enact on her fetus or child; she follows in her mother's footsteps by revealing a negative attitude toward motherhood.

The men in the novel make Dewey Dell's condition shameful as Moseley's reaction shows. Darl, who knows Dewey Dell's secret, expresses the shame of her condition, not Dewey Dell herself. In a rage about her desire to go to town if their mother dies, Darl condemns her actions: "The reason you will not say it is, when you say it, even to yourself, you will know its true: is that it? But you know it is true now. I can almost tell you the day when you knew it is true. Why wont you say it, even to yourself...You cannot believe that it is true because you cannot believe that Dewey Dell, Dewey Dell Bundren, could have such bad luck: is that it?" (AILD 27). The judgments of Darl and Moseley further enforce the idea that the mother's body is an object that is always judged whether it is a married body or not. When placed in society, the female body, the "womb of time" (AILD 78), is an object of judgment, because no pregnant woman can ever fulfill the perfect roles of wife and mother set out for her. By wanting to commit an act of violence against her fetus, Dewey Dell causes the community to reaffirm their ideological image of the proper mother.

Whether wife, mother, or pregnant woman, Dewey Dell's final appearance in the novel enforces the idea that the pregnant body is an object of physical and ideological exploitation. Like Addie's corpse, Dewey Dell's corporeal, pregnant body becomes a space where violence is enacted in order to maintain the social order. When she goes to another pharmacy in Jefferson, Dewey Dell's pregnant body becomes a commodity ripe for sexual exploitation as an object of exchange. Unlike Moseley, who tries to do the "honorable" thing, MacGowan takes advantage of Dewey Dell's lack of education. By pretending to be a doctor, MacGowan claims that if he gives Dewey Dell the abortifacients, he could lose his license; he explains the risk in order to 
entice Dewey Dell to offer sex in exchange for her "medicine" and an "operation." Of course, the "medicine" MacGowan gives to Dewey Dell is a placebo, not an abortifacient, and the "operation" is sex itself. At the end of the novel, Dewey Dell believes she has what she needs to be free of her pregnancy, but the reader knows that she has essentially been raped or "violated" as Addie likes to say. Like Addie, Dewey Dell has been tricked by pregnancy (and by her “doctor"), and eventually, she will enact her revenge on the community that refused not only her body but her wishes. Ultimately, Dewey Dell's fate will be similar to her mother's; both women relate violence toward children as a subjective moment that reveals their desires outside of traditional motherhood. The mother's body becomes doubly unclean through both her abject status as well as her violent desires. In the end, violence becomes the narrative through which the mother's subjectivity is revealed both from herself and from the community whose ritual chanting of the ideology of motherhood continues to abject her.

The violations are not over for Dewey Dell, and it is her father, Anse, that offers the final violation. Discovering Dewey Dell's possession of Lafe's ten dollars, Anse takes the money from her, claiming, "I have fed you and sheltered you. I give you love and care, yet my own daughter, the daughter of my dead wife, calls me a thief over her mother's grave" (AILD 174). The reader is finally given a concrete example of how Anse uses words, especially the word "love," to express obligation and not emotional connection. Anse takes the money and uses it to purchase his new teeth. Presumably, the teeth are used by Anse to make him more desirable to the woman who becomes the next Mrs. Bundren. Taking from Dewey Dell, another mother's body, through words, Anse reveals his ultimate impotence as a patriarchal figure. Like his teeth, the new Mrs. Bundren, like Addie, is an object needed by Anse in order to give him the appearance of respectability. Faulkner shows how the construction of patriarchy and masculinity 
are performances that rely on constructions of femininity. In the end, the reader empathizes with Addie's conflicted subjectivity related to her role as mother, an ideological construction whose marginalization of desire reveals the mother as an ideological object.

Perhaps more profane than "homo sacer" is the idea of the violent mother. Addie's violence is what makes her "mater sacer." This violence serves a purpose: to deconstruct the boundaries between the physical body (through violence and desire) and the ideological body. As Agamben writes of State power and subjectivity, "Everything happens as if, along with the disciplinary process by which State power makes man as a living being into its own specific object, another process is set in motion that in large measure corresponds to the birth of modern democracy, in which man as a living being presents himself no longer as an object but as the subject of political power" (9). This move from object to subject is exactly what Faulkner reveals through Addie's body. The text presents an object, a corpse, for speculation as a result of a patriarchal power structure, but as the text continues, Addie speaks for herself in the central stream-of-consciousness passage of the novel. As a result, Addie shifts from object to subject. She is no longer a body interpreted through the ideological ideals of family and community. Instead, she is the "sublime subject" who can no longer only function as an object. "Mater Sacer" has been killed, but the ritual cleansing of the community replaces the ritual sacrifice. Addie's death reinforces the ideological norms necessary for the continuation of the community and the heteronormative family. Through physical violence, ideological violence is revealed as the sublime source of the sacred. 


\section{Chapter Three}

Only Disconnect: Ruth Wilcox, Death, and the Sublime Object in Howards End

In an aside regarding Leonard Bast's extortion of his family after he falls into abject poverty, the narrator remarks, "Society is based on the family, and the clever wastrel can exploit this indefinitely" (Howards End 271). Although the quip about the wastrel is tongue in cheek, Forster points to the fact that much of the discourse surrounding identity and social relations invests in preserving the family as a necessary social unit. E. M. Forster's Howards End explores the complexities of family and its relationship to state and legal structures-a relationship currently critiqued in Queer Theory. Stressing the importance of German philosophy on the development of the modern and humanist subject, Forster reveals two contrasting family structures through the orphaned Schlegels and the traditional Wilcoxes. These two families appear opposite in every way. The Schlegels are liberal, artistic, frivolous, and naïve, and their clan consists of the eldest, Margaret, her sister, Helen, and her brother, Toby. The Wilcoxes are conservative, patriarchal, logical, and a cog in the colonial and capitalist machine. Henry and Ruth are pater and mater, aging holdovers from the Victorian era, and their children represent the privileges of a white, middle-class existence that results from the exploitations involved in British imperialism. In addition to the Schlegels and Wilcoxes, Leonard Bast and Jacky are unmarried for most of the novel, engaging in a sexual relationship that would have been considered inappropriate at the time. Leonard, in particular, desires to inhabit the privileged life of art and knowledge that his working class social position everywhere thwarts; his desire for upward mobility (both financially and educationally) are constantly deterred by the interference and actions of the middle and upper classes. At the end of the novel, Helen reappears as an unwed mother yet part of the new, integrated family that Margaret builds. 
Howards End is a complex novel that creates circular arguments and presents ideological constructions as problematic while often reinforcing those structures. In many ways, Howards End represents human nature by showing the complexities of belief and action. What Margaret espouses as a part of the Schlegel clan is not the role that she enacts throughout the novel. Mrs. Wilcox appears to be the idealized Victorian mother, replete with essentializing notions of gender, but her ability to transcend life after death locates her outside of the boundaries of society. In all, there is no easy answer to the problems of Howards End. Despite its exploration of family, a structure typically associated with heteronormativity, Forster everywhere sees subjects whose lived experiences contradict their social roles, beliefs, and actions. Considering his repeated emphasis on German philosophy, especially Immanuel Kant, throughout the novel, Forster explores intersubjectivity revealed through sublimity as a way of challenging traditional, heteronormative family structure. I explore sublimity through the transcendent figure of Mrs. Wilcox, connecting recent work in Queer Theory that explores the possibility of family and kinship and Slavoj Žižek's concept of the "sublime object of ideology." More specifically, Forster's use of the problems of property and legal ownership point to a trend in the novel that draws attention to the relations between marriage and the state that reinforce a heteronormative family. By stressing the problems of state involvement in the construction of the family, Forster begins to challenge the validation of the family by the state in favor of spiritual forms of kinship. In order to propose a new kinship system, Forster explores moments of emotional connection that result in the production of a queer concept of family.

In his work on reproductive futurism, Lee Edelman develops the concept of the "sinthomosexual," a queer figure that causes rupture in the heteronormative construction of family. Forster ruptures family structure through the use of a sinthomosexual character in the 
figure of Mrs. Wilcox. Ironically, it is the most heteronormative of figures (the idealized Victorian mother) that offers the transcendent encounter that Edelman discusses. Edelman's configuration of the sinthomosexual as a "sublime object" suggests that abject status of the queer in a heteronormative ideological structure that parallels the abject status of the mother in patriarchy. In either case, both Edelman and Forster use a person rather than an object to reveal a sublime encounter, and this person becomes what I term a "sublime subject." The "sublime subject" is a character, a subject, who would traditionally inhabit the position of the "object" in the subject/object dynamic of the traditional sublime. Like the sublime object, the "sublime subject" reveals the interplay between constructed and lived identity categories as another subject comes to understand and empathize with the ideological restrictions placed upon the sublime subject.

I do not read these characters as objects, but as inhabiting the position that a physical object would in the traditional sublime. As a result, I use the term "sublime subject" in order to convey a shift in aesthetic discourse that combats subject/object discourse and reinforces the idea of intersubjectivity. Ultimately, I argue that Howards End reveals how Edelman's "sinthomosexual" figure (whose abject status provokes a sublime experience) actually reinforces the idea of a queered family through the promotion of intersubjectivity — an idea that Edelman's theory posits as an impossibility. By making Mrs. Wilcox that figure, Forster explores the concept of "queer" that reflects its most recent incarnations in Queer Theory, and he also reveals how Edelman's concept of the "sinthomosexual" is in many ways a Žižekian "sublime object." Žižek and Edelman rely on Lacanian psychoanalysis in such a way as to rupture the real and reveal nothingness; however, for Žižek, the sublime object provides this rupture while for Edelman it is the sinthomosexual. Both theorists suggest the need for a rupture of ideology 
structures related to their specific identity focus. For Žižek, economics, politics, and class concerns reveal this rupture while for Edelman, heteronormative social structures are in need of deconstruction. In both cases, there is clear inattention to gender in their critiques and an avoidance of the mother as an abject figure, which Julia Kristeva also constructs using Lacanian psychoanalysis. Unlike Edelman who suggests that we "fuck the children," Forster shows that a queer future can never be removed from the figure of the child as Helen's "bastard" baby inherits the physical property Howards End (which represents the traditional family) as well as a family structure that offers new patterns of kinship.

\section{Queering Žižek’s “Sublime Object”}

Since Lee Edelman draws on Lacanian psychoanalysis and the Marxist theories of Slavoj Žižek, it is not surprising that Edelman's "sinthomosexual” and Žižek's "sublime object” have much in common in the way that they are theorized. Contemporary theorists of the sublime approach the subject from a psychoanalytic perspective. ${ }^{1}$ Slavoj Žižek uses Lacanian psychoanalysis in order to discuss the ideological implications of the sublime object. Žižek develops his argument by assessing multiple theorists of the sublime, but considering his investment in ideology, he mainly focuses on the Hegelian model of the sublime. Like Immanuel Kant, Hegel struggles with many of the same questions of transcendence, empiricism, and epistemology in his discussions of art. Although many critics have questioned the purpose of Kant's aesthetics, de Man asserts that Kant's concern regarding aesthetics is both epistemological and political ("Hegel" 106) — an articulation regarding aesthetics that is most fully realized by and credited to Hegel.

Žižek shows how Kant's emphasis on the newly emerging modern subject relates to the psychoanalytic processes that Lacan explores as the basis of his theories of subjectivity. In his 
analysis of a Lacanian psychoanalytic approach to the sublime, Žižek credits Kant's depiction of the sublime as anticipating "Lacan's determination of the sublime object" (Žižek 229). ${ }^{2}$ In Žižek's discussion of the sublime object, the subject embraces the sublime object and the failure inherent in that object: "Thus, by means of the very failure of representation, we can have a presentiment of the true dimension of the Thing" (Žižek 229). The failure functions to expose the void and offer the subject a moment of recognition involving the larger forces that structure epistemology, philosophy, and ideology. On Kant and the sublime, Žižek writes,

The sublime is therefore the paradox of an object which, in the very field of representation, provides a view, in a negative way, of the dimension of what is unrepresentable. It is a unique point in Kant's system, a point at which the fissure, the gap between phenomenon and Thing-in-itself, is abolished in a negative way, because in it the phenomenon's very inability to represent the Thing adequately is inscribed in the phenomenon itself. (230)

The contradiction of the sublime lies in the fact that the failure of representation is the foundational experience of the sublime; however, the sublime itself is meant to point to that very gap in reason. Negativity is then exposed, and it is this negativity that ruptures perception and allows reason to intervene. Ultimately, what Žižek suggests is the sublime moment of rupture is the moment when the negativity inherent in the process of subjectivity is revealed. Like trying to define a word by using the word itself, the sublime experience paradoxically shows the moment of failure to understand as the definitional moment of the sublime experience. I suggest that through a similar psychoanalytic process, "queer" can function in much the same way as the sublime in aesthetic theory as the definitional problems surrounding the term "queer" mark similar elisions involving attempts to define the sublime. 
The definitions of "queer" often reflect two potential meanings: one that connects "queer" specifically with homosexuality and a second that explores the larger social, political, and ideological implications. The second definition tries to avoid exclusion through an idea of boundlessness that does not specifically ascribe to one type of non-heteronormative sexuality. Like many theorists, it is this second category or definition of "queer" that I find the most compelling for its potentially radical political, social, and aesthetic concerns. Although many queer theorists focus on a definition of the term "queer," others expose the problematic nature of attempts at definition. Carla Freccero explores "queer" for its function as a critique rather than an identitarian construct (15); "queer" is a "non-identity-based critical cultural and political practice that seeks to resist the humanist rights-bearing claims of collective identities understood to be based in a certain affective and sexual practice" (15). More recent definitions of "queer" critique the heavy-handed use of constructionist discourse in queer theory as a way of defining and discussing identity politics. ${ }^{3}$ In essence, it is difficult to define the word "queer" as its meaning allows for fluidity among definitions of status related to sexuality that the term itself is meant to elide. Like the sublime object, "queer" represents a paradoxical identification for the modern subject.

Stemming from this strong critique of identity politics is Lee Edelman's more progressive connections between queerness and psychoanalysis in his analysis of the "sinthomosexual"; this critique invokes a similar psychoanalytic approach to queer that critics like Slavoj Žižek have applied to discussions of the sublime. Edelman invokes psychoanalytic theory in order to expose the place of queerness in ideological structures. Of queerness, Edelman writes in his polemic "that taking the Symbolic's negativity to the very letter of the law, that attending to the persistence of something internal to reason that reason refuses, that turning the force of 
queerness against all subjects, however queer, can afford an access to the jouissance that at once defines and negates us" (5). In his discussion of the queer specifically, Edelman continues by insisting that the subject's access to jouissance "can expose the constancy, the inescapability, of such access to jouissance in the social order itself, even if that order can access its constant access to jouissance only in the process of abjecting that constancy of access onto the queer" (5). As Edelman's work asserts, the queer emphasizes the nothingness located everywhere-even in the queer. In a similar move, Žižek deconstructs the Kantian sublime into nothingness based on a psychoanalytic reading that stems from Lacan: "[T]he Sublime is no longer an (empirical) object indicating through its very inadequacy the dimension of a transcendent Thing-in-itself (Idea) but an object which occupies the place, replaces, fills out the empty place of the Thing as the void, as the pure Nothing of absolute negativity - the Sublime is an object whose positive body is just an embodiment of Nothing" (234). Like the "sinthomosexual" in Edelman, the object of the sublime invokes a moment of recognition, of conception where the subject is able to wrap his mind around the nothingness that the sublime experience exposes.

Žižek's emphasis on the unraveling to nothingness as a part of the sublime experience parallels the dismantling experiences of the subject. Edelman's stress on the person, the sinthomosexual as a potential sublime object accentuates the idea that both the subject and the sublime reveal a contradiction that covers up nothingness. In essence, the experience of the sublime is like the symbolic interaction of the subject: both suggest a conflict between the Real and the Ideal. Žižek's postmodern analysis of the sublime removes the empirical insistence on the object as sublime (like in Burke) and further emphasizes the individual, aesthetic experience that allows the subject to realize his inability to conceive of boundlessness or a great magnitude that is sublime. The realization of nothingness, the opposite and yet the same as the infinite 
often invoked in the sublime, is the ultimate perceptual moment in the Kantian sublime. By opening up the space of the subject in tandem with the sublime experience, Žižek anticipates a move toward an unraveling of the subject that Edelman invokes through his discussion of the "queer." The emptiness and nothingness provoked by the Freudian death drive become the psychoanalytic entry into understanding the complex nature of both the queer and the sublime.

Edelman's assessment of the sinthomosexual, de Man's interpretation of Kant's ultimate materialism, and Žižek's discussions of sublime objects are all invested in the deconstruction of the signifying process in order to expose the letter rather than meaning. ${ }^{4}$ Through jouissance, Edelman addresses queerness and Žižek explains the space between the Real and the representation as the sublime object. Jouissance is found in this space, but the meditation of pleasure and pain make it discoverable. Using Lacan, Edelman explains that "queerness...is never a matter of being or becoming but, rather, of embodying the remainder of the Real internal to the Symbolic order" (Edelman 25). For Edelman and Lacan, this remainder is jouissance: "a movement beyond the pleasure principle, beyond the distinctions of pleasure and pain, a violent passage beyond the bounds of identity, meaning, and law" (Edelman 25). One of the key conceptual components of the sublime (particularly for Kant) is the problem of the production of pain that is at the same time pleasurable. ${ }^{5}$ Using this particular conundrum often associated with the sublime, Žižek proposes jouissance as the excess space where the sublime object can be found: 'Sublime is 'beyond the pleasure principle,' it is a paradoxical pleasure procured by displeasure itself (the exact definition — one of the Lacanian definitions — of enjoyment [jouissance])" (Žižek 228-229). Thus, the psychoanalytic space of queerness is located in that void between the Real and the symbolic, between pleasure and pain, which is where the sublime experience is located. Žižek's discussion of sublime objects examines the division between the 
thing (the object) and its representation. He does not attempt to examine if and when a person might provoke a sublime experience and function as a sublime object. Instead, Žižek relies on the subject/object and self/other binaries of Lacanian psychoanalysis to exclude the potential of a sublime moment that is produced when a person acts as the sublime object. I propose that it is at this point that Edelman takes Žižek one step further through the configuration of the sinthomosexual in Queer Theory; Edelman's sinthomosexual is the realization of a person as a sublime object or what I term the "sublime subject."

Sinthomosexuality uses the queer figure endowed with a power to obliterate meaning and cultural fantasy in order to provoke a moment of recognition about meaning and cultural fantasy itself - a moment of individual and internal recognition that mimics the sublime encounter. The queer, who often elides a strict definition and the representable, becomes what Žižek calls "paradox of an object, which, in the very field of representation, provides a view, in a negative way, of the dimension of what is unrepresentable" (Žižek 230). In an encounter with a sinthomosexual, a human sublime object, a subject must confront their ability to imagine the unimaginable and to conceive of the unconceivable: "here, where the aesthetic imagination is strained to the utmost, where all finite determinations dissolve themselves, the failure appears at its purest" (Žižek 230). The sinthomosexual functions in society in much the same way that the violent shipwreck viewed from a cliff or a thunderstorm assessed from afar pushes the mind's limits in order to understand, perceive, and conceive of its terror without being under the spell of actual terror. In society, the sinthomosexual provokes the recognition of "terror" through its potential ability to obliterate the social structure. As Edelman puns, sinthomosexuality denies: the appeal of fantasy, refusing the promise of futurity that mends each tear, however mean, in reality's dress with threads of meaning (attached as they are to the eye-catching 
lure we might see as the sequins of sequence, which dazzle our vision by producing the constant illusion of consequence)—offers us fantasy turned inside out, the seams of its costume exposing reality's seamlessness as mere seeming, the fraying knots that hold each sequin in place now usurping that place. (Edelman 35)

Like the shipwreck or the thunderstorm, the sinthomosexual represents the obliteration not only of the self but also the social structure and this becomes the sublime object of society. By exposing the death drive and the rhetoric of futurism, Edelman's text insists that society recognize the "terror" that the sinthomosexual is and represents. In this encounter, the real threat of the sublime object (and thus the sinthomosexual) is the exposure of the nothing that lies behind all social structures and this exposure is the sublime moment.

In Edelman, the "sinthomosexual" is a queer figure who exists outside the boundaries of society but who ruptures the social structure. Although Edelman claims that "All sexuality...is sinthomosexuality, but the burden of figuring that condition, the task of instantiating the force of the drive (always necessarily a partial drive, one incapable of totalization) that tears apart both the subject's desire and the subject of desire, falls only to certain subjects who...serve as fall guys for the failure of the sexual relation and the intolerable reduction of the subject to the status of sinthome" (Edelman 73). The figure functions as a sinthome who undermines symbolic patterns and becomes "the site at which meaning comes undone" (Edelman 35). This "site" that undermines meaning exists outside of symbolic or ideological structures and as such inhabits an abject space. The abject figure, for Edelman, is typically a male figure; however, Antigone (as read through the work of Judith Butler) is an abject figure resulting from the taboo relations of incest. In her configuration of the abject, Julia Kristeva emphasizes the mother as such a figure whose position offers the possibility of jouissance. Yet, Edelman insists that jouissance puts 
"reproductive futurism at risk" (39). Edelman wants to figure "jouissance" with queerness while ignoring the feminist construction of jouissance and its relationship to abject figures, particularly the mother. In fact, in a text that considers jouissance through the figuration of an abject figure, any reference to Kristeva is completely absent. For, to make his construction of the abject, sinthomosexual figure work, Edelman must completely ignore the abject status of the mother for she is the pinnacle from which reproduction stems. As Edelman writes, "Those figures, sinthomosexuals, could not bring the Symbolic order to crisis since they only emerge, in abjection, to support the emergence of Symbolic form, to metaphorize and enact the traumatic violence of signification whose meaning-effacing energies, released by the cut that articulates meaning, the Symbolic order constantly must exert itself to bind" (Edelman 106). As abject figures, sinthomosexuals should bring the Symbolic to crisis, but in effect, they actually draw attention to Symbolic meaning.

Still, Edelman claims that the sinthomosexual challenges heteronormativity in a way that becomes an "ethical task for which queers are singled out" (Edelman 109). Edelman asserts that a "sinthomosexual" is the "formalization of a resistance to the constant conservation of forms, the susbstantialization of a negativity that dismantles every substance" and leads a figure toward jouissance (109). Edelman invests in a very particular politics that focuses on gay male subjectivity, and as a result, the figures that Edelman examines (i.e., Scrooge from A Christmas Carol, Silas from Silas Marner, Leonard from North by Northwest) are typically men. Edelman's figuration of the sinthomosexual draws attention to the abject figure who inhabits the space where meaning ruptures, and despite his queer and anti-reproductive stance, Edelman's figure can also be the mother. Abjected due to her reproductive capabilities, the mother offers yet another space where the tension between negativity and jouissance plays out as a rupture to 
symbolic meaning. Or, in the case of this study, Edelman's abject sinthomosexual articulates how the dead mother can offer access to sublimity, the ultimate rupture of ideological meaning through its transcendent function.

And so enters Forster, a queer author who explores the subjectivity of not only men but women, and as a result, he makes the mother figure central to his narrative while suggesting that she is also a queer figure. For in Howards End, there is no more boundary defying character than the person who has died and more importantly, who still lives as a transcendent voice to future generations. Mrs. Wilcox becomes the "sinthomosexual" figure, the "sublime subject" who ruptures all boundaries and reveals the negativity, the nothingness of modern, capitalist, and imperialist life to the other characters. Mr. Wilcox is nothing without a Mrs. Wilcox (whether Ruth or Margaret). Helen has no family without both Margaret and her son. While Edelman wants to foresee a future without children, Forster, through Helen's baby, actually imagines a queer future where a bastard child inherits property, a woman becomes the head of a household, and the patriarch is revealed as the impotent figure he always was. For Forster, change begins with the mother (Mrs. Wilcox) and ends with the mother (Helen). There is no possibility of a queer future or a queer family without the reproduction of children. Forster subverts the rhetoric of the child that reinforces heteronormativity and posits a queer family.

Michael Warner and David L. Eng both propose new ways of rethinking queerness in terms of the family. In essence, Forster's queer vision of the family very much aligns with more radical interpretations of family and kinship. Of marriage, Michael Warner says,

But it does not mean that marrying should be considered as an ethical problem. It is a public institution, not a private relation, and its meaning and consequences extend far beyond what a marrying couple could intend. The ethical meaning of marrying cannot be 
simplified to a question of pure motives, conscious choice, or transcendent love. Its ramifications reach as far as the legal force and cultural normativity of the institution. (107)

In essence, Warner suggests that marriage proposes an ethical problem as its institutionalization links it from the personal to the political. It is the rhetoric surrounding marriage that vies for an ethical component; whereas, Warner proposes an "ethics of shame" that "holds queer culture together" for it is: "A relation to others...begins an acknowledgement of all that is most abject and least reputable in oneself' (35). As Margaret repeatedly challenges Henry, Helen's appearance (and her shame at her pregnancy) emphasizes the abject in Henry's behavior (his shame at having a mistress). Like Warner, Forster sees shame as the foundation of all relationships. Through his examination of race, Eng ultimately suggests the following: "There is no one law of kinship, no one structure of kinship, no one language of kinship, and no one prospect of kinship. Rather, the feeling of kinship belongs to everyone" (198). Eng's conclusion very much parallels Forster's fictional representation of a queer family at the end of Howards End. Forster shows that kinship is in essence a "feeling" rather than a law. By linking property rights to marriage and finally to the construction of family, Forster emphasizes not only a queer vision of the family as Robert K. Martin has suggested but also that intersubjectivity is the key to that new form of family. ${ }^{6}$ Through an "ethics of shame" and a "feeling of kinship," a subject can finally connect to others as subjects rather than objects of political systems.

\section{Mrs. Wilcox and Her Inheritance}

Forster comments on the history of modern subjectivity related to aesthetics through references to Kant early in Howards End, offering commentary on British society through German philosophy. In particular, in describing the younger Schlegels, the narrator remarks that 
they are of British and German ancestry, offering a transnational position as the reason for the bohemian and not "English to the backbone" (Howards End 24) actions of the Schlegel sisters. It also accounts for Margaret and Helen's interest in women's rights and issues of class, showcasing the inconsistence of the British class system from an outsider position. In describing Mr. Schlegel, Margaret, Helen, and Toby's father, the narrator remarks, "He was not the aggressive German, so dear to the English journalist, nor the domestic German, so dear to the English wit. If one classed him at all it would be as the countryman of Hegel and Kant, as the idealist, inclined to be dreamy, whose Imperialism was the Imperialism of the air" (Howards End 24). In this configuration of German imperialism, Forster references a philosophical tradition whose discourse represented the "ideal." The philosophical tradition of the enlightenment is foundational to the construction of the modern subject. Here, the reference to "idealization" and the "Imperialism of the air" reflects a move toward ideologically loaded thought whose discourse contradicts lived experience. The language suggests that philosophical discourse is foundational to the construction of imperialism. Through imagination and perception, one creates "idealized" social structures that make imperialism possible. Later in the passage, the narrator directly connects the pre-World War I nation state of Germany to its philosophical inheritance, offering a similar imperial narrative of Germany that is later used as a result of World War I. And yet, the ironic tone of the narrator's voice regarding Germany implies that England is every bit as much imbedded in the same sort of imperialism as Germany.

Forster shows that discourse and the symbolic objects that discourse maintains create and reflect ideology. Unlike the Germans, the narrator comments on the failure of the British imagination, an aesthetic term often associated with the Kantian sublime. The narrator remarks, "It is the vice of a vulgar mind to be thrilled by bigness, to think that a thousand square miles are 
a thousand times more wonderful than one square mile, and that a million square miles are almost the same as heaven. That is not imagination. No, it kills it. When their poets over here try to celebrate bigness they are dead at once, and naturally" (Howards End 24). This passage comments on the idea of bigness linked to transcendence, which if considering the Burkean sublime, remarks on the British empirical approach to aesthetics that lacks emotion. However, German Romantic thinkers and poets are also reconciled to nothingness in the early twentieth century: "Your [Germany's] poets too are dying, your philosophers, your musicians, to whom Europe has listened for two hundred years. Gone. Gone with the little courts that nurtured them-gone with Esterhaz and Weimar" (Howards End 25). The narrator links the decline of "Britishness" with that of German imperialism. Importantly, the narrator's use of aesthetics in order to connect Britain and Germany implies that cultural texts relay ideological structures that the novel then attempts to decode and undermine — especially race, gender, and class.

Mrs. Wilcox is a unique character in Howards End as she functions as a transcendent figure both before and after her death. Maternal death and the maternal body have been an often discussed topic in criticism of Victorian literature, especially as regards the "maternal death plot." ${ }^{, 7}$ In modernism, the discussion of maternal death or the maternal body is tinged by Freudian psychoanalysis. Carolyn Dever has argued that the "maternal death plot" of Victorian literature influenced Freud's fixation on the maternal body as an object (3). As a result of the mother's death, the orphaned hero or heroine creates a "disembodied ideal" of the mother, which objectifies the dead mother (6). In Howards End, this plot is literally realized through the absence of the Schlegel mother; however, the Schlegel father rather than the mother is the parent most often remembered in the text. Although not using the term "disembodied ideal" in regards to the mother, Lois Cucullu also focuses on maternal death in modernist fiction, noting that 
modernist authors kill the mother in an elitist move that separates modernism from its Victorian precursors (6). The "Victorian woman's institutional eviction" (Cucullu 6) validate modernists own cultural and artistic norms by producing "a repressive tropology that justified their interventions in household autonomy and sanctioned their expert remedies" (Cucullu 29). Ultimately, Cucullu argues that this approach allows for the reinforcement of traditional norms regarding gender. This shift away from the "maternal death plot" is realized through the use of Mrs. Wilcox. Rather than glorifying the Schlegel mother, Forster presents the reader with a mother-substitute - a trend that can also be seen in the relationship between Lily Briscoe and Mrs. Ramsay in Virginia Woolf's To the Lighthouse. In Howards End, the mother does not die at the beginning of the novel but well into the novel. Unlike the Victorian "maternal death plot," the lateness of maternal death in Howards End allows the reader to develop a sense of the mother's subject position. ${ }^{8}$

Ultimately, Mrs. Wilcox is perceived as a Victorian domestic Angel by her family, but the inclusion of her character early in the novel clearly shows that the family's perception of their mother contrasts with Mrs. Wilcox's spiritual views regarding Howards End and its heir. Howards End signifies a gendered, domestic ideological structure that confines and situates women to the house; however, it is important that this image is constructed by others, not Mrs. Wilcox. Mrs. Wilcox's family expresses emotional grief by associating Mrs. Wilcox with an object. In essence, the family objectifies emotion, using Howards End as a substitute for the emotions the family feels about the wife or mother. As they live at Howards End after Mrs. Wilcox's death, the Wilcoxes feel the loss of their wife and mother in connection with the house: "It was in the other rooms, and especially the garden, that they felt her loss the most" (79). As the passage continues, Mrs. Wilcox's children, Charles and Evie, ruminate on the loss in terms of 
Howards End. When Mrs. Wilcox bequeaths the house to Margaret, the children feel betrayed as the loss of Howards End emphasizes the loss of a maternal body that they only understood as an ideal of Victorian domesticity. The Wilcoxes' anger at Mrs. Wilcox results from their inability to connect with her, and as a result, disconnection becomes central to the Wilcoxes' way of life. As Margaret implies to Helen: "It is sad to suppose that places may ever be more important than people" (111). Although Howard End, the place, is important to the people, Forster shows through Mrs. Wilcox's death that in loss, the place only ever signifies the lost person. The inability of the Wilcoxes to understand Mrs. Wilcox's choice of heir results from their inability to deal with the emotional complications of grief. More than grief, the real betrayal behind Mrs. Wilcox's choice of heir (Margaret) for Howards End is that in her final hour, she fails to fulfill the completely self-sacrificing role of the Victorian mother. Instead, she makes a last request that reveals her desires, and the failure of the Wilcoxes to accept her desire creates a situation where Mrs. Wilcox becomes a transcendent figure who expresses her desires from beyond the grave.

Mrs. Wilcox often functions as a mediator throughout the novel through manipulations involving Howards End both before and after her death. Žižek defines the sublime object as a physical object that exists in an in-between position, seen but not seen clearly; similarly, many subjects inhabit in-between positions that promote sublime encounters, offering a "sublime subject." As Žižek writes, "The sublime object is an object which cannot be approached too closely: if we get too near it, it loses its sublime features and becomes an ordinary vulgar object - it can persist only in an interspace, in an intermediate state, viewed from a certain perspective, half-seen" (192). In other words, like the traditional sublime, distance is a key component in revealing the transcendent and encountering the sublime moment. Throughout the 
novel, both Mrs. Wilcox and Howards End are only "half-seen." In the opening scene, Forster employs distance by having Helen recount her description of Howards End and Mrs. Wilcox through a letter. The first glimpse the reader has of Howards End and Mrs. Wilcox is via literal distance through the reception of a letter. Helen reveals Howards End only partially, focusing on the internal structure of the house:

It isn't going to be what we expected. It is old and little, and altogether delightful—red brick....From hall you go right or left into dining-room or drawing-room. Hall itself is practically a room. You open another door in it, and there are the stairs going up in a sort of tunnel to the first floor. Three bedrooms in a row there, and three attics in a row above. That isn't all the house really, but it's all that one notices-nine windows as you look up from the front garden. (Howards End 21)

Immediately, Forster shows the interspace between what Howards End is imagined to be like and what it is. From the beginning, the house is not the ideal, and even as she looks more closely, Helen refuses to see the house as what Žižek terms an "ordinary vulgar object." Howards End only exists from a view that clouds reality—much like the function of any ideological structure.

Like the house, Mrs. Wilcox is also revealed through Helen's letter as someone who is not looked at too closely; she is a goddess, an ideal, rather than a mother. Helen describes Mrs. Wilcox as such: "I looked out earlier, and Mrs. Wilcox was already in the garden. She evidently loves it. No wonder she sometimes looks tired. She was watching the large red poppies come out. Then she walked off the lawn to the meadow....Trail, trail, went her long dress over the sopping grass, and she came back with her hands full of the hay that was cut yesterday" (22). Both the image of Mrs. Wilcox and Howards End contrasts with what Helen expected: "I only wanted to show that it isn't the least what we expected. Why did we settle that their house would 
be all gables and wiggles, and their garden all gamboge-coloured paths? I believe simply because we associate them with expensive hotels-Mrs. Wilcox trailing in beautiful dresses down long corridors, Mr. Wilcox bullying porters, etc" (22). From the beginning of the novel, both the house and Mrs. Wilcox fail to live up to expectations, and as a result, they both exist in an in-between space for other characters and the readers. If one looks too closely, the ideal image will crumble and only an ordinary object or person will appear. As a result, both Mrs. Wilcox and Howards End are portrayed from a distance as looking too closely will reveal the ideological structures that dictate the human relationships in the text.

Mrs. Wilcox as angelic figure becomes even more pronounced after her deathsuggesting that family and society have constructed a particular image of Mrs. Wilcox that does not actually reflect her own passions and desires exhibited in her relationship with Howards End. Like the passages from Helen's letter and the narrator that describe her as angelic or goddesslike, Mrs. Wilcox's own thoughts are rarely ever told from her point-of-view or her perspective. It is the narrator who remarks that Mrs. Wilcox's life is spent in sacrifice to the Wilcox men: "Mrs. Wilcox, whose life had been spent in the service of husband and sons, had little to say to strangers who had never shared it, and whose age was half her own. Clever talk alarmed her, and withered her delicate imaginings; it was the social counterpart of a motor-car, all jerks, and she was a wisp of hay, a flower" (Howards End 63). In this passage, Mrs. Wilcox is separated from the masculine discourse that surrounds her, and in the case of her family, much of their dialogue reflects on or occurs within the motor car. Through her denial of capitalist progress, she silently confronts the men in her family with a more spiritual concept of progress.

The most potent images of Mrs. Wilcox are from the eyes, thoughts, and dialogue of others, implying that others perceive her as a Victorian Angel of the house whether she actually 
inhabits that role or not; this becomes especially apparent after her death. In fact, Mrs. Wilcox's funeral is a spectacle - consumable by both her family and the people from the area surrounding Howards End. Like any act of grief or mourning, the dead figure immediately inhabits a transcendent image on the griever's mind. Interestingly, this mourning is depicted not through Mrs. Wilcox's family but through a local worker: "He tried to tell his mother down below all that he had felt when he saw the coffin approaching; how he had almost slipped out of the tree, he was so upset; the rooks had cawed, and no wonder-it was as if rooks knew too. His mother claimed the prophetic power herself-she had seen a strange look about Mrs. Wilcox for some time" (Howards End 75). Like Mrs. Wilcox herself, the worker's mother invokes a feeling of intuition, whereas, her son felt the loss of this woman. Despite this small relief of grief, the class commentary becomes even more pronounced: "The funeral of a rich person was to them [the lower class locals] what the funeral of Alcestis or Ophelia is to the educated. It was Art; though remote from life, it enhanced life's values, and they witnessed it avidly" (Howards End 75). Forster associates middle/high class funerals with an act of viewing art; he implies that death holds an aesthetic value for onlookers. Forster uses the local workers' perspective like the aesthetic disinterestedness required in the evaluation of art. The emotional component of grief is completely separated from the funeral spectacle which functions as art for those who have no access to the intellectual elite. Through the depiction of aesthetic disinterestedness, Forster shows the impact of class on the evaluation of art. More importantly, depending on class, art escapes its traditional, reified position. Like any piece of art, Mrs. Wilcox becomes part of a spectacle that connects transcendence to her death.

Mrs. Wilcox's transcendent position as supreme orchestrator is what marks her as a sinthomosexual figure based on her literal otherworldliness. Her position allows many 
characters to attribute a grand design to her that ultimately results in the construction of an expanded form of family that includes both Wilcoxes and Schlegels. Mrs. Wilcox's transcendence lies in her connection to the past and to an England rooted to the land. Jed Esty has coined this British modernist move toward the past as part of the "shrinking island" that reveals the "relationship between a fading imperialism and the putative death of English modernism (understood as the last major phase of English literature)" (2). The first hint of Mrs. Wilcox's supreme intuition is during the brief, muddled love affair between Helen Schlegel and Paul Wilcox. As Mrs. Munt charges to Helen's rescue, Mrs. Wilcox quickly intervenes in a way that shows her superior knowledge: "She approached just as Helen's letter had described her, trailing noiselessly over the lawn, and there was actually a wisp of hay in her hands. She seemed to belong not to the young people and the motor, but to the house, and to the tree that overshadowed it" (HE 36). From the beginning of the text, Mrs. Wilcox is associated not only with nature but also with the house. More importantly, the house represents an agricultural tradition that emphasizes the importance of fertility. ${ }^{9}$ She belongs to the land and to a precapitalist England that is distanced from the imperial Wilcoxes-for Mrs. Wilcox is really a Howard at heart. By moving different people in the text into contact with one another, Mrs. Wilcox revives the essence of the fertile and lost England through Helen Schlegel and her baby boy. In addition, by linking Mrs. Wilcox to nature, Forster suggests that a radical break from social structure or any personal epiphany must come from an encounter with the natural world. In the traditional sublime, a sublime moment most often occurs through an encounter with nature. With consistent emphasis on Mrs. Wilcox as part of nature, Forster makes encounters with her foundation to a sublime experience that reveals a return to a more fertile and agrarian past. 
More importantly, Mrs. Wilcox's transcendent status as orchestrator to a new form of family is revealed only after her death; in essence, due to her representational connection to the land, Mrs. Wilcox refuses to remain dead, defying the traditional narrative of the "death drive." In his discussion of sinthomosexuality, Edelman says the sinthomosexuals are made to represent the death drive: "Sinthomosexuality...affirms a constant, eruptive jouissance that responds to the inarticulable Real, to the impossibility of sexual rapport or of ever being able to signify the relation between the sexes....Sinthomosexuality, then, like the death drive, engages, by refusing, the normative stasis, the immobility of sexuation to which we are delivered by Symbolic law and the promise of sexual relation" (74). In the Freudian death drive, there is a drive toward stasis or to one's original inanimate state, and by associating Mrs. Wilcox with nature, Forster already places her in defiance of the death drive to which she will succumb. She is connected to the land, and as a result, she can never truly achieve stasis. Land becomes linked to property and property correlates to inequalities in class. For a woman, land and property align with marriage as a social institution.

By interposing property rights related to marriage with spiritual evaluations of "proper" heirs, Forster reveals that the possibility of a queer family in the future only exists if Mrs. Wilcox's desires constantly recirculate. Until others recognize her desires, Mrs. Wilcox refuses the "normative stasis" of staying dead through sexual relations that promote reproduction. By trying to find a spiritual heir to her property, Mrs. Wilcox defies the Freudian death drive, which as Edelman suggests, is the project of "reproductive futurism." By placing an emphasis on heirs (whether spiritual or legal), Forster engages in a project that invests in the future through the figure of the child. Unlike Edelman, Forster uses the mother figure as a sinthomosexual figure. By encountering Mrs. Wilcox, the Schlegels and Wilcoxes are enmeshed in a way that 
completely disrupts their reality. They must confront the heteronormative expectations of legal and state systems like marriage and ownership, but in Forster's future, the family no longer falls in line with expected patterns of kinship and the child represents a queer future with a queer family.

Mrs. Wilcox's transcendence is most often recognized by Margaret both before and after her death. During the special luncheon thrown in honor of Mrs. Wilcox, Margaret repeatedly feels the distinction between the progressive, social position of her and her friends and the old fashioned ways of the past. Still, Mrs. Wilcox's presence provokes a feeling of greatness. According to the narrator, "She [Mrs. Wilcox] was not intellectual, nor even alert, and it was odd that, all the same, she should give the idea of greatness. Margaret, zigzagging with her friends over Thought and Art, was conscious of a personality that transcended their own and dwarfed their activities" (80). The importance of Mrs. Wilcox as transcendent or great emphasizes the power of her personality even before her death. By revealing her as a transcendent figure, Margaret identifies her spiritual precursor, and by marrying Mr. Wilcox, she later identifies the importance of Mrs. Wilcox's transcendent power and her ability to orchestrate the comingling of past and present. The mother figure becomes the vehicle through which the past and present can combine to reimagine the family.

The almost supernatural Miss Avery, the housekeeper at Howards End, showcases the combination of the past and present by revealing the history of the Howards. In many ways, Miss Avery functions as the physical envoy of Mrs. Wilcox in order to orchestrate the merging of the Schlegels and Wilcoxes. On a visit with Henry, Margaret encounters a house filled by Miss Avery with her family objects. More importantly, Miss Avery foresees the creation of a queer family, signified by the cradle that she places in the nursery. Miss Avery remarks to 
Margaret: "You think that you won't come back to live here, Mrs. Wilcox, but you will" (Howards End 234). When Margaret enters the house, the narrator recounts: "They went into the dining-room, where sunlight poured in upon her mother's chiffonier, and upstairs, where many an old god peeped from a new niche. The furniture fitted extraordinarily well. In the central room-over the hall, the room that Helen had slept in four years ago-Miss Avery had placed Tibby's old bassinet" (Howards End 234). From these passages, Miss Avery is the physical medium through which Mrs. Wilcox reveals her plans for Margaret at Howards End; she is the voice through which the spiritual and transcendent is revealed.

Miss Avery displays not only the voice of the future, but more importantly, the voice of the past. She reveals much of the history of the Howards. As Margaret discusses her furniture with Miss Avery, the narrator comments: "In the house Margaret had wondered whether she [Miss Avery] quite distinguished the first wife from the second" (Howards End 237). Miss Avery sees Margaret as the spiritual heir before she even decides to live at Howards End. As a result, Miss Avery reveals the history of the family and the first Mrs. Wilcox: "I never saw much of Ruth after her grandmother died, but we stayed civil. It was a very civil family. Old Mrs. Howard never spoke against anybody, nor let anyone be turned away without food. Then it was never 'Trespassers will be prosecuted' in their land, but would people please not come in? Mrs. Howard was never created to run a farm" (Howards End 237). Like D.H. Lawrence in The Rainbow, Forster beckons to an agrarian past before the interference of systems of property that require rules about trespassing. The personal history of the Howards is marred by the construction of property rights. In essence, the private is everywhere dictated by the interference of the public realm. After revealing the past, Miss Avery goes on to again reach toward the future: “A better time is coming now, though you've kept me long enough waiting. 
In a couple of weeks I'll see your lights shining through the hedge of an evening" (Howards End 237). Miss Avery represents both the past and the future and merges the two. She appears in the text to reveal how the past sculpts the future and how that future is always in some ways destined by a transcendent force. In Howards End, that force just happens to be attributed to the intuitive powers of Mrs. Wilcox-even from beyond the grave.

Towards the end of the novel, each character associates the creation of the queer (and perhaps utopian) family at Howards End to the grand design of Mrs. Wilcox. In their forbidden night at Howards End, Margaret and Helen discuss the collision of past event and the present as part of an unknown scheme: "Except Mrs. Wilcox, dearest, no one understands our little movements" (HE 268). After the revelation of Helen's pregnancy, Margaret is forced to choose between her new affiliation with the Wilcoxes and with Helen's disenfranchised position. At Howards End, Margaret feels peace: "The peace of the country was entering into her. It has no commerce with memory, and little with hope....Margaret awoke and looked into the garden. How incomprehensible that Leonard Bast should have won her this night of peace! Was he also part of Mrs. Wilcox's mind?" (HE 269). As she assumes more and more responsibility for the Wilcoxes, Margaret continues to see Mrs. Wilcox's "mind" as orchestrating the "peace of the present, which passes understanding" (HE 269). Margaret continues to see Mrs. Wilcox as a transcendent figure whose force moves both families (and even Leonard Bast) toward Howards End. The house becomes the physical object that must be encountered in order to reveal the grand design of Mrs. Wilcox — a design that eventually rewards Margaret as heir both spiritually and legally.

The novel suggests that Howards End follows a matrilineal tradition and that the transfer of the house to the patriarchal Wilcox family disrupts this precedent. ${ }^{10}$ When Margaret insist 
that she be able to spend the night with Helen at Howards End, Mr. Wilcox's patriarchal rights come to forefront: "The house is mine - and Charles, it will be yours - and when I say that no one is to live there I mean that no one is to live there. I won't have it....To my mind the question is connected with something far greater, the rights of property itself" (HE 278). Mr. Wilcox tries to use force to maintain Howards End as part of a patriarchal inheritance; however, at this very instant, the house shelters the family that Mrs. Wilcox dictated as its spiritual heir. The house itself links to an agrarian tradition which reinforces the maternal (and fertile) line represented by the Howards and Schlegels. Mr. Wilcox appears as a usurper meant to interrupt this tradition. Although it appears that matriarchal and patriarchal systems of inheritance are placed at odds with one another, the text does not ultimately support such binary thinking. Although Mr. Wilcox may obtain the property rights for the house, Howards End remains inhospitable for family life throughout most of the novel. Mr. Wilcox appears to have outwitted Mrs. Wilcox's spiritual heir, but as the text progresses, Mrs. Wilcox enforces her desires from beyond the grave. The house realizes its matriarchal inheritance through the figure of Margaret but only if it merges with the patriarchal Wilcoxes. Forster does not seem to want to fall into such a simple maternal/paternal or feminine/masculine binary. Instead, he proposes that in order for Howards End to survive, the maternal and paternal traditions must connect.

\section{Leonard's Death, Sublimity, and a Queer, Intersubjective Family}

More than any other character, the specific language used to describe Leonard Bast most closely echoes descriptions of the sublime. Through the image of the abyss, Forster invokes the idea of infinity, which is often associated in constructions of the sublime by both Burke and Kant. ${ }^{11}$ In the novel, the abyss is most explicitly associated with issues of class, and Forster refers to the abyss as a terrifying precipice into which the poor may fall. Leonard, who is so 
immersed in the problems of class and unable to achieve any upward mobility, cannot create the emotional distance necessary for a sublime encounter. The sublime moment is only accessible to those who can achieve perspective through distance. Leonard is the figure who represents the terrifying totality of the abyss to the upper classes (including both Schlegels and Wilcoxes); however, due to their financial situations, these families are able to create an emotional distance from Leonard. When he dies at the end of the text, Leonard symbolizes an encounter with the abyss as viewed with aesthetic disinterestedness. Unlike Mrs. Wilcox, Leonard functions as a "sublime object" whose encounter makes a queer family possible while also reaffirming the status of the middle class. In Howards End, intersectionality is impossible. For a revisioining of gender and sexuality, class must be sacrificed. More than anything, Forster points to the notion that addressing the problems of one identity category is most often done at the sacrifice of another.

Forster links the image of the abyss, the infinite, with Leonard, marking him as a "sublime object." When Leonard is first introduced, the narrator describes,

He was not in the abyss, but he could see it, and at times people whom he knew had dropped in, and counted no more. He knew that he was poor, and would admit it....But in his day the angel of Democracy had arisen, enshadowing the classes with leathern wings, and proclaiming, "All men are equal —all men, that is to say, who possess umbrellas," and so he was obliged to assert gentility, lest he slipped into the abyss where nothing counts, and the statements of Democracy are inaudible. (Howards End 56)

Leonard lives on the precipice of the abyss - in terror over whether or not he would slip over. Unlike the aesthetic distance required in the sublime moment, Leonard's failure lies in his inability to gain that distance through the problem of money. He reads Ruskin and attends 
Beethoven symphonies; however, the narrator describes Leonard's interests as beyond his reach due to the problems of the working class. When Helen comes to rescue Leonard from starving, the narrator remarks, "But Leonard was near the abyss, and at such moments men see clearly" (Howards End 200). At this moment, Leonard sees the division of the classes or as he says, “There always will be rich and poor" (Howards End 200). He is given a momentary reprieve by Helen who finally thrusts him into the abyss. After Helen brings him to Oniton, Leonard becomes completely impoverished. No longer able to support himself, he must beg from his family. After this last mention of the abyss at Oniton, Forster does not use the term again as regards Leonard. He represents the abyss, and once he finally slips into that abyss, Leonard dies. Due to his class, Leonard realizes that he never really mattered. In many ways, he was already dead.

Leonard's death makes literal his dismissal throughout the text as a person who represents an idea. He is the character that is always a representation - the image of the lower classes for Helen and Margaret and the abyss of the sublime. Echoing his conversation with Helen earlier in the text, as Leonard approaches Howards End, the narrator writes, "Death destroys a man, but the idea of death saves him - that is the best account of it that has yet to be given. Squalor and tragedy can beckon to all that is great in us, and strengthen the wings of love. They can beckon; it is not certain that they will, for they are not love's servants. But they can beckon, and the knowledge of this incredible truth comforted him" (Howards End 276). Here, Forster highlights the tension surrounding Leonard that plays out throughout the rest of the novel. Ideas kill Leonard like the books that "fell over him in a shower" (Howards End 277). ${ }^{12}$ Leonard is the idea or the representation of the poor, and in this way, he is the Žižekian "sublime object" of ideology. Like Mrs. Wilcox, Leonard is representative of an ideological construction. 
Unlike Mrs. Wilcox, Leonard is simply forgotten; his subjectivity and desires are never revealed in the way that Mrs. Wilcox's are. Howards End goes to the proper spiritual heir as Mrs. Wilcox wishes, but due to his class, Leonard can never obtain the upward mobility that he desires. Even worse, he is literally an object used by Helen in their sexual encounter and quickly forgotten. Despite fathering her child, Helen is unable to feel a connection to Leonard. Helen reveals her role in Leonard's death, but she continues to consider him an object: "I ought to remember Leonard as my lover....I tempted him, and killed him, and it is surely the least I can do. I would like to throw out all my heart to Leonard on such an afternoon as this. But I cannot. It is no good pretending. I am forgetting him" (Howards End 286). Like a sinthomosexual figure, Leonard's abject poverty places him at the periphery of society, unable to cross either class or intellectual barriers. Like Mrs. Wilcox and the sinthomosexual, Leonard's abjection causes the moment of rupture through his death. Unlike Edelman, who is only invested in a singular view regarding sexuality, Forster's positioning of different abject figures throughout the novel suggests that his tagline "only connect" is actually an exercise in intersectional analysis. Leonard's abject status causes an encounter that results in his death; however, he cannot become a transcendent figure like Mrs. Wilcox. The narrator implies that Mrs. Wilcox sends Leonard to Howards End, but he is simply an object used to fulfill her aims. In this case, Leonard functions as a sinthomosexual figure who produces the child that will represent a queer future. He does not, though, become a "sublime subject" in the sense that Mrs. Wilcox does. In his death as in his life, Leonard is forgotten and his desires are never readily accepted.

According to the narrator, Mrs. Wilcox sends Leonard to Howards End as a sacrifice that combines the yeoman (represented by the Howards) and the imperialist (represented by the Wilcoxes). The country surrounding the house beckons to Leonard; however, considering the 
amount of time spent linking Mrs. Wilcox to this particular land, Mrs. Wilcox moves Leonard to Howards End. The narrator comments, "[A]nd the country, however, they interpreted her, was uttering her cry of 'now'. She did not free Leonard yet, and the knife plunged deeper into his heart as the train drew up to Hilton. But remorse had become beautiful" (HE 275). In addition, when Leonard finally arrives at Howards End, he says, "Mrs. Wilcox...I have done wrong" (HE 276). Although he directs this statement to Margaret, the use of "Mrs. Wilcox" suggests a larger transcendent lineage that has found its spiritual heir. Ariela Freedman argues that "a man's death replaces a woman's death and in doing so gains narrative primacy as the male character loses the effect of narrative agency," and she goes on to say that Howards End "associates death with male subjectivity and concomitantly predicates an excess of female agency, women characters able to predict or determine not only their own narrative futures but even, to some degree, the event of the male other's death" (41). Freedman reads Leonard as the sacrifice necessary to make way for a feminine and matriarchal tradition; however, the narrator of the novel suggests that the sacrifice of Leonard fulfills Mrs. Wilcox's orchestrations to combine the Schlegels and Wilcoxes (the feminine and masculine). One particular problem in the text is the fact that Leonard must be sacrificed in order for two middle-class strains (humanist and imperialist) to combine. Forster suggests that imperialist, capitalist, and patriarchal ideology produce multiple sites of abjection, and as a result, he envisions a future through a socioeconomically queer figure. Like Edelman, Forster also suggests that an abject figure must sometimes be sacrificed in order to rupture dominant ideological structures and their meanings. Ironically, though, the working class Leonard's son will eventually inherit Howards End-suggesting that a queer family can only be created through the combination of low and upper classes in the figure of Helen's baby. 
With Leonard's death, the imperialist Wilcoxes are destroyed, paving the way for the eventual recognition of Mrs. Wilcox's desires and her heir. Of imperialists, the narrator draws a comparison to the yeoman farmers found around Howards End:

At the chalk-pit a motor passed him [Leonard]. In it was another type whom nature favors - the Imperial. Healthy, ever in motion, it hopes to inherit the earth. It breeds as quickly as the yeoman, and so soundly, strong is the temptation to acclaim it as a superyeoman, who carries his country's virtues overseas. But the imperialist is not what he thinks or seems. He is a destroyer. He prepares the way for cosmopolitanism, and though his ambitions may be fulfilled the earth that he inherits will be gray. (HE 276)

Although the Wilcoxes are involved in ventures overseas, this imperialist history and critique play out over the property of Howards End - a part of the earth. Through the issue of ownership and Howards End, Forster depicts the destruction wrought on the "earth" or the "world" through imperialism on British soil. He problematizes the British mindset represented by the Wilcoxes that seeks to inherit land only to destroy it. After the death of Leonard, the Howards End that the Wilcoxes inherit is now "gray," and as a result, the property finally passes to its proper heirMargaret.

Leonard's death becomes the moment, the sublime moment, upon which the rest of the text resolves and functions. Deprived of the yearly income of the Schlegels or the capitalist income of the Wilcoxes, Leonard lives in the abyss, striving for upward economic mobility. Unlike the Schlegels and Wilcoxes, Leonard's position gives him no distance from the abyss; whereas, the Schlegels and Wilcoxes are in distanced positions that allow them to comment on Leonard's position. The violence of his death marks the moment when he falls completely into the abyss - giving the crisis necessary for Margaret (the voice of "proportion" and reason) to 
intervene. More importantly, Howards End, a sublime object, creates this moment and functions as a physical substitute for Mrs. Wilcox's (the mother's) body. The narrator comments, "No there was nothing more to be done. They had tried not to go over the precipice, but perhaps the fall was inevitable....At such moments the soul retires within, to float upon the bosom of a deeper stream, and has communion with the dead, and sees the world's glory not diminished, but different in kind to what she has supposed" (HE 282). Leonard's death throws Margaret into a sublime moment that connects each member of the two families. Later, the narrator writes, "[T]here was beauty and adventure behind, such as the man at her feet had yearned for; there was hope this side of the grave; there were truer relationships beyond the limits that fetter us now. As a prisoner looks up and sees stars beckoning, so she, from the turmoil and horror of those days, caught glimpses of the diviner wheels" (HE 281). Margaret's sublime moment comes in the realization that the social limits that dictate proper family roles must be broken, and in doing so, Margaret glimpses another form of family that transcends imperial England. Like Jane Austen's Elinor Dashwood on which she is based, Margaret becomes the voice of reason that helps create a queer, intersubjective family.

Through this act of violence toward Leonard, the patriarchal Wilcox line breaks, and in order to survive, the traditional notions of family must be forsaken. Ironically, the legal system (that the Wilcoxes supported) claims Mr. Wilcox's son, Charles, through an indictment of manslaughter: "The verdict was brought in. Charles was committed for trial. It was against all reason that he should be punished, but the law, being made in his image, sentenced him to three years' imprisonment. Then Henry's fortress gave way. He could bear no one but his wife, he shambled up to Margaret afterwards and asked her to do what she could with him. She did what seemed easiest — she took him to recruit at Howards End" (284). The male Wilcoxes have been 
completely dismantled. Through crisis, Henry is finally forced to connect, and as a result, he becomes lost: "Not ill. Eternally tired. He has worked very hard all his life, and noticed nothing. Those are the people who collapse when they do notice a thing" (HE 286). Henry's collapse marks a move away from his imperial mindset and into a space where he must recognize the power structures that dictated his life. He finally "noticed a thing" and that "thing" is that all is not the same.

The dismantling of the Wilcoxes results from their refusal to "only connect," which is the ethical imperative of the novel. Margaret's mainly criticizes Henry for his refusal to notice other people. When Helen's shameful pregnancy is revealed, Margaret chastises Henry for his callousness:

You shall see the connection if it kills you, Henry! You have had a mistress-I forgave you. My sister has a lover-you drive her from the house. Do you see the connection? Stupid, hypocritical, cruel—oh, contemptible! - a man who insults his wife when she's alive and cants with her memory when she's dead. A man who ruins a woman for his pleasure, and casts her off to ruin other men. And gives bad financial advice, and then says he is not responsible. These men are you. You can't recognize them, because you cannot connect. I've had enough of your unweeded kindness. I've spoilt you long enough. All your life you have been spoilt. Mrs. Wilcox spoiled you. No one has ever told you what you are-muddled, criminally muddled. Men like you use repentance as a blind, so don't repent. Only say to yourself: "What Helen has done, I've done." (Howards End 264)

As Margaret so aptly points out, the problem of the Wilcoxes is their refusal to connect on a personal level and make any sort of empathetic gesture. For the Wilcoxes, the interactions 
between people are problems that must be solved in order to maintain appearances and conform to ideological expectations. In the future, the Wilcoxes who reproduce heteronormative patriarchy must be dismantled, because they do not try to connect. These moments of connection are the intersubjective backbone around which Forster will reimagine a queer family unit. $^{13}$

Later in the text, Margaret reveals what the sublime interaction with Leonard shows to her; reason has intervened and shows other subjectivities. Margaret says to Helen,

It is only that people are far more different than is pretended. All over the world men and women are worrying because they cannot develop as they are supposed to develop....A place, as well as a person, may catch the glow. Don't you see that all this leads to comfort in the end? It is part of the battle against sameness. Differences-eternal differences, planted by God in a single family, so that there may always be colour; sorrow perhaps, but colour in the daily gray. Then I can't have you worrying about Leonard. Don't drag in the personal when it will not come. Forget him. (HE 287)

Margaret examines what her experience has brought to her attention. Forster expresses the problem of "social constructions" and of families who fail to conform to the expected mold that legal and social systems have dictated for them. What Forster refers to as "differences" recognizes other subjectivities that exist outside of a British, white, middle-class power structure: Leonard's poverty, Helen's position as a single mother, Mrs. Wilcox's desires for a spiritual heir. Helen learns to like Henry despite her claims that she never will—but only after the exposure of the weight of imperialism and patriarchal masculinity (HE 286). The "sublime object," Howards End, uncovers patriarchal and political ideological structures. By acting as a force beyond the grave, Mrs. Wilcox becomes the "sublime subject" who makes disempowered subjectivities 
visible and intersubjectivity possible. By focusing on an abject figure who functions like Edelman's sinthomosexual but resists his insistence on inhumanity and a resistance to empathy, the queer becomes a key figure through which intersubjectivity might actually be realized. In reality, despite Edelman's construction, the sinthomosexual is a problematic figure whose characterization as the space of rupture reiterates his/her function as an object. "Queer," which is supposed to be a more inclusive term than those used in Gay and Lesbian studies, in Edelman's hands, actually becomes an exclusionary practice. By considering the possibility of intersubjectivity, Forster invokes the queer figure as key to mutual recognition and realizes a more fluid understanding of subjectivity.

Forster strengthens his position by having Howards End left legally to Margaret, validating the idea of a spiritual heir and uniting that concept with primogeniture. Through the final act of will writing, Forster successfully shows the merger of humanism and imperialism, feminine and masculine, and spiritual and legal. Mr. Wilcox proclaims, "Then I leave Howards End to my wife absolutely....And let everyone understand that; and after I am dead let there be no jealousy and no surprise" (HE 290). Mr. Wilcox finally leaves the property legally to Margaret and recognizes Mrs. Wilcox's original desire for a spiritual heir. He then goes on to say that Margaret "intends when she dies to leave the house to her-to her nephew, down in the field" (HE 290). So, the house is left to a male, which reflects the patriarchal tradition of primogeniture; however, by constantly associating the baby with the fields and nature, Forster also suggests that patriarchy and matriarchy have combined to produce this new, ideal subject. Finally, at the end, Dolly reveals Mrs. Wilcox's wishes to Margaret: "It does seem curious that Mrs. Wilcox should have left Margaret Howards End, and yet she get it, after all” (HE 290). When he reveals the story of Mrs. Wilcox's "will" to Margaret, Henry asks Margaret if he did 
wrong. Margaret responds, "You didn't, darling. Nothing has been done wrong" (HE 291). With this brief statement, Margaret subtly acknowledges Mrs. Wilcox's transcendent presence, showing that places as well as people have "diviner wheels." The spiritual nature of Mrs. Wilcox's wish resulted in the conclusion expected despite legal interference.

Ironically, like many heteronormative tales, Forster uses the image of the child as a representative of a more hopeful future. Lee Edelman has discussed this representation of a figural child as part of "reproductive futurism" or "For the social order exists to preserve for this universalized subject, this fantasmatic Child, a notional freedom more highly valued than the actuality of freedom itself, which might, after all, put at risk the Child to whom such a freedom falls due" (11). For Edelman, the child is an idealized citizen "entitled to claim full rights to its future share in the nation's good, though always at the cost of limiting the rights 'real' citizens are allowed" (11). Edelman disparages this figural child as part of a project to reinforce heteronormativity and the prevalence of the biological family. Forster, despite his position as a queer writer, still places importance on the child as a figure that represents the future for a more fluid, queer version of family. With this child, intersubjectivity is always already present as his "family" is less biological and more those members chosen by Mrs. Wilcox. ${ }^{14}$ Forster has anticipated Valerie Lehr's comments on the relationship between community and family:

Two-parent families only make sense as a practical necessity if children are born into families isolated from larger community networks. That is, if it is possible for children to be exposed to and interact with a diverse array of human beings as they are nurtured to adulthood, the theoretical justifications generally put forth for needing two-parent homes lose their power. (110) 
Like Lehr, Forster wants to re-envision family as a communal effort; his vision is more inclusive and should prove to be fertile, which is perhaps why Forster so heavily links Helen's baby to the land. In addition, the baby's best friend will be Tom — a working class farm hand that represents the breakdown of class barriers. In this queer, intersubjective family, Helen's son represents the same form of "reproductive futurism" that Edelman so critiques. Beginning with the death of the maternal body, the transcendent Mrs. Wilcox defies death by demanding the recognition of her desires. Mrs. Wilcox oversees the chess-like game that positions different families and persons into relationships that resist objectification, including the sacrifice of a pawn, Leonard Bast. Leonard's death does in fact rupture the symbolic order, and counter to Edelman's claims, this socioeconomically queer figure lives on because of reproductive futurism. Although Helen may forget him, Leonard's baby goes on to inherit Howards End and offer the possibility of an intersubjective family. Forster uses this image of a child but to a queer purpose. Instead of invalidating the biological, Forster suggests that the future lies in the collision of multiple subjectivities that expand beyond the boundaries of the biological family. In Forster's future, this new version of family will be as fertile as the land that Howards End symbolically represents. 


\section{Chapter Four}

Ursula's Disempowered Rainbow: Sublime Intersubjective Mother/Father Relationships in D.H. Lawrence's The Rainbow

When Mellors declares to Connie Chatterley, “Tha'rt good cunt, though, aren't ter? Best bit o' cunt left on earth. When ter likes! When tha'rt willin'!" (Lady Chatterley's Lover 177), it is difficult for the feminist critic not to discard Mellors's remarks as those of a misogynist D.H. Lawrence. In the past forty years, the image of D.H. Lawrence as a misogynist has held sway in the academy. Despite this aspect of his critical reputation, I have always been drawn to Lawrence's well-crafted verse, beautifully constructed prose, and subtle representations of the struggles inherent in human relationships and sexuality. In Lawrence, I find not a man set in his ways but a man trying to work through the shifting discourses surrounding gender in the early twentieth century as a result of discussions about the physical body, sexuality, and reproduction connected with the Women's Rights movement. In many ways, the political and social arguments about women's rights at this time focused on the two most powerful images left over from the Victorian imaginary: the spouse and the parent. For women, this imaginary includes the potent images of the good wife and mother. ${ }^{1}$ In Lawrence's writing, some women accept socially proscribed roles and others rebel against them. Considering the range of different female characters in his work, Lawrence was interested in women: how they lived, how they engaged in marriage, how they revealed their desires, and how modern women are different from the women who came before them. Considering the variety of women he depicts throughout his oeuvre, why have feminist critics often considered Lawrence simply masculinist and misogynist?

In her foundational work on patriarchy, Kate Millett's Sexual Politics traces a line of misogyny in male writing that she considered stemmed from Lawrence. In this text, Millett explores how Lawrence uses Freudian psychoanalytic discourse and the Victorian idea of the 
frigid woman as "superb instruments for the perfect subjugation of women" (241). In her reading of feminist responses to Lawrence's work, Carol Siegel succinctly summarizes the line of feminist criticism post-1970 (or post-Millett): "Whether their approach is thematic, deconstructive, historicist, or psychoanalytic, feminist critics seem to find Lawrence useful. Almost as predictably as their works tell us that gender differences exist, they also tell us that Lawrence represents all that does not belong to woman" (5). As she continues, Siegel summarizes the work of many feminist critics who have explored Lawrence from a feminist perspective, including Annis Pratt, Sandra Gilbert, Susan Gubar, Mary Jacobus, and Eve Sedgwick (5-6). Siegel goes on to suggest, "We should look as skeptically at feminist descriptions of Lawrence that reduce him to a symbolic Other as we do at patriarchal reductions of women writers" (6). Following Siegel's lead, I examine Lawrence's work as exploring both the feminine and the masculine, which combats the "common feminist assumption that Lawrence conceived his literary persona in opposition to the female voice” (Siegel 6).

Like Carol Siegel's work, post-1990 scholarship on Lawrence has been influenced by the trend in literary studies to give a more historicized accounting of literature. ${ }^{2}$ This relatively recent scholarship takes into account Lawrence's extensive critical writing on literature, philosophy, and psychoanalysis as a reaction to earlier feminist scholarship that Siegel examines. In the 1980s, Carol Dix draws attention to the need for a reconsideration of Lawrence that avoids essentialism, and Hilary Simpson argues that there should be "a new basis for the discussion of Lawrence's work — in particular that part of it concerned with sexual relationships and roles — by examining it in relation to selected aspects of women's history and the development of feminism" (15). In the 1990s, the call for more nuanced critique is answered as Linda Ruth Williams explores "how, despite his negative pronouncements, Lawrence contradicts himself, 
enjoying the visual, experimenting with forms of narrative which are cross-fertilised by cinema technique, looking with the eyes of femininity" (2). Cynthia Lewiecki-Wilson explores Lawrence's constructions of family in conversation with Sigmund Freud's Oedipus Complex. She suggests two reasons why "Lawrence's work may be profitably investigated from an alternative, feminist point of view" (12). The first is that Lawrence disagreed with Freud and the second is that "all Lawrence's work...is in one way or another, about the problem of gender" (12). Anne Fernihough combines an ideological and aesthetic approach to Lawrence's work that considers his critiques of philosophical, aesthetic, and psychoanalytic discourses that reinforce his belief that idealism is dangerous to the subject (7) and that the material world must not be aesthetically idealized (9). In the last ten years, titles like Radicalizing Lawrence and Reclaiming D.H. Lawrence show a shift away from considering Lawrence as conventionally masculinist. This recent work does not point to a right way to read Lawrence but rather suggests his representations of identity and subjectivity are complex. All of this critical work shows that Lawrence had very particular arguments with the discourses of his time. He challenged aesthetics as dangerous to the subject, he reexamined Freud, and he was vested in first wave feminism. These historically conscious approaches all show that Lawrence constantly challenged social discourses in ways that examine rather than reinforce traditional gender structures. In fact, in his writings on psychoanalysis and in the novel The Rainbow, Lawrence explores both gender and sexuality in ways that reveal the tensions between a biological understanding of sex and its social construction.

The Rainbow traces the married and sexual relationships of three generations of the Brangwen family. Originally titled "The Wedding Ring," the novel shows the impact of Victorian gender ideologies on the construction of the modern family. The novel opens in the 
early to mid-nineteenth century with the courtship and marriage of Tom to the foreigner, Lydia, a widow with a young daughter, Anna. Tom and Lydia's marriage showcases fluid gender and sexual roles. The novel then follows the second generation through the courtship of Anna to Will. In this second generation, the family structure is complicated by the severe demarcation of gender roles during the mid-to-late-nineteenth century. The novel then progresses to the early twentieth century and depicts the struggles of a third generation child, Ursula, who confronts rapidly changing gender and sexual roles. ${ }^{3}$ By tracing three generations, as Carl Krockel and Erwin R. Steingberg suggest, Lawrence places importance on the mythic and redeeming the past in his work. Using literal generation through reproduction, Lawrence places importance on the past as a way of understanding the present. By contrasting the relationships of Tom/Lydia and Will/Anna, Lawrence examines the tensions created through the conflict between outmoded gender structures and the need for change in order to combat the problems of modern life.

I argue that Lawrence juxtaposes a successful sublime relationship in Tom and Lydia with a failed sublime relationship in Will and Anna in order to demonstrate that transcending ideological constructions of gender will result in human connection and emotion. In rewriting the sublime as an intersubjective rather than subject/object experience, Lawrence contests constructions of masculinity and femininity that gendered aesthetic and social discourses stemming from the Enlightenment. By combining both pleasure and pain, Lawrence rethinks the sublime in terms of emotional distance in relationships between two people, specifically parents. Rather than glorifying reason (as Immanuel Kant does in the sublime), Lawrence places particular importance on intuition and emotion as a way to defy subject/object dynamics in favor of exploring subjectivity between two people. By depicting a reciprocating, intersubjective sublime experience between Tom and Lydia, Lawrence challenges the basic tenet of 
psychoanalysis and the sublime: the "objectification" of others to confirm an ego-driven self. Lawrence proposes sexual difference to unify two unknowns in such a way that loneliness of the modern subject can be avoided through emotion and connection. By emphasizing the importance of emotion, Lawrence sees another possibility for human civilization that no longer requires the suppression, sacrifice, repression, or objectification of the feminine. In other words, he sees a society improved through the acceptance of the feminine. Lawrence's rewriting of the sublime centers on birth not death, emotion not language/discourse, and relationships rather than subjects and objects. ${ }^{4}$ Lawrence shows how pain and pleasure can be located in birth, in the bringing of a new subject into the world, in the opportunity for change and regeneration. He shows how one's ability to "feel" for another human being rather than "reason" one's ego-driven knowledge can produce a transcendent moment of empowerment through connection rather than distance.

In order to understand the complexity of Lawrence's representations of male/female relationships related to the sublime in The Rainbow, I must first give a brief overview of Lawrence's critical perspectives on gender, psychoanalysis, and aesthetics. All of these discourses influenced Lawrence as a writer and a thinker whose own modernist approach to these subjects involved a complex, interlocking process. In essence, Lawrence's aesthetics are rooted in a new language that confronts the gendered philosophical, scientific, and literary discourses he inherited. Lawrence's perspectives on the subject/object approach of psychoanalysis in conjunction with his reading of Kant as the source of modernist displacement offer a subversive reading of gender and the sublime. The deterioration of the sublime experience through multiple generations of the Brangwen family reflects a larger social decay that Lawrence relates to Victorian gendered ideologies. He finds Victorian gender roles confine both men and women, 
resulting in the modernist feeling of displacement and fragmentation. In all, Lawrence's theorization of relationships stems directly from a rejection of subject/object psychoanalysis in favor of human emotion, feeling, or instinct that transcends empirical knowledge related to gender and sexuality, which Lawrence sees as resulting directly from a Kantian system of reason.

\section{Lawrence, Gender, and Aesthetics}

While writing The Rainbow, Lawrence was interested in the Women's Movement's aim to reform not only women but also modern civilization. Lawrence hoped that men would adopt some of the qualities traditionally associated with women in order to create a less destructive and more empathetic society (Simpson 16). In first wave feminism, suffragettes and women fought for legal rights and public access, a struggle that required them to become more aggressive, internalizing traditionally masculine roles in order to fit into a patriarchal and capitalist society. But, Lawrence hoped society would adopt feminine attributes as a way of counteracting masculine modes of power. Lawrence believed that the feminist movement would cause a social revolution; however, after World War I, he is disappointed that this did not happen (Simpson 17). Lawrence wanted a balance between the sexes that did not erase but encouraged difference. For him, each person balanced a "masculine" and "feminine" nature that is often termed a "bisexual" constitution — a common belief among many modernist writers as a result of

sexology. ${ }^{5}$ This fight for balance also appears in Lawrence's aesthetic concept of "supreme art." As Mark Kinkead-Weekes writes, "supreme art" is "neither self-expression, nor the pitting of the self against the other to the submission of one" (164). Instead, it is an act of balance or equality that ends in reconciliation (Kinkead-Weekes 164). This aesthetic rejects the either/or approach of binary thinking in favor of a balance between two identities. Lawrence believed that the need 
for balance in gender relationships links to his art and that both will solve the destructive, masculine path of civilization.

Lawrence responds to binary thinking about sexuality and gender in Psychoanalysis and the Unconscious and Fantasia and the Unconscious. Lawrence claims that these two tracts are developed from his depiction of relationships in his novels and poetry (Fantasia and the Unconscious 57), and as a result, they can be applied to his earlier work, The Rainbow. Sigmund Freud and Carl Jung's work in psychoanalysis was well-known to Lawrence's acquaintances as well as Lawrence himself (although there is no direct evidence that he read Freud). ${ }^{6}$ Lawrence was friends with Barbara Low and Ernest Jones, Freudian psychoanalysts, and David Eder, who studied Freudian and Jungian psychology. His later writing also indicates that he was interested in Freudian and Jungian psychoanalysis during the time he composed The Rainbow (Worthen 219). In Psychoanalysis and the Unconscious, Lawrence reinforces Jung's concept of the "collective unconscious" as he questioned Freud's construction of the unconscious in the process of repression related to sexuality through the Oedipus Complex. Instead, Lawrence believed that "psychology had to start from the very inception of human consciousness" (Kinkead-Weekes 554). Lawrence thus sees human consciousness less situated in difference than in one consciousness. As The Rainbow shows, individual consciousness comes full circle-starting as one consciousness, separating into two (through sex and self/other formulations), and coming to one again through marriage between the sexes (although not in an institutional but a spiritual sense). Lawrence believed that mental consciousness can grow, change, and adapt.

Lawrence reads Freud's discussion of neuroses as normal or as making the "disease the norm" (Kinkead-Weekes 554). Lawrence sees Freud as part of project that makes repression normal. Through Lawrence's interpretation (or perhaps misinterpretation) of Freud, the subject 
becomes diseased as s/he becomes aware of that repression even though Freud sees this act as curing the subject. As Kinkead-Weekes points out, for Lawrence, repression creates a system that does not allow change or growth, which opposed all of Lawrence's beliefs that the struggle between the sexes can lead to balance (554). In Lawrence's essay, the conscious/unconscious binary plays out in gendered terms, showing that the discourse of psychoanalysis as subject/object is embedded in his fiction. Lawrence drastically rewrites binary thinking as balancing and collapsing, creating a mythic or spiritual union instead of the fragmented modern subject responding to an emotionless, oppressed and repressed object.

Fantasia and the Unconscious extends Lawrence's discussion of Freud through a critique of the Oedipus Complex in favor of Lawrence's physiological concept of the "solar plexus" (or body response). Like Freud, Lawrence invests in heterosexual family structures, and he also engages in contradictory language similar to that of Freud. In his essay, "Femininity," Freud implies an understanding of gender roles as constructed while at the same time reinforcing a connection between gender and biological sex. In his analysis of psychoanalysis, Lawrence falls into a similar trap as he tries to reconcile gender construction with discourses that justify a biological division of the sexes. This tension surfaces when Lawrence makes the following claim: "A child is born sexed. A child is either male or female, in the whole of its psyche and physique is either male or female....The talk about a third sex, or about the indeterminate sex, is just to pervert the issue" (Fantasia and the Unconscious 131). Lawrence goes on to call the "third sex" a "hermaphrodite fallacy," and through this fallacy, Lawrence teases out the idea of gender as constructed: "Man, in the midst of all his effeminacy, is still male and nothing but male. And woman, though she harangue in Parliament or patrol the streets with a helmet on her head, is still completely female. They are only playing each other's roles, because the poles 
have swung into reversion. The compass is reversed. But that doesn't mean that the north pole has become the south pole, or that each is a bit of both" (Fantasia and the Unconscious 135, my emphasis). Although relying on an essentialist idea of gender, Lawrence implies that gender roles can be played by any sex. Implicitly, Lawrence sees gender as constructed; however, he also wants to see gender as related to a biological essence. In both Freud and Lawrence, psychoanalytic thought had not progressed to the point of a clear articulation between gender and sex; neither Freud nor Lawrence was able to reconcile the two concepts within the limited discourses of the time.

A "third sex" is inconceivable to Lawrence, because it blends maleness and femaleness without any interest in how their differences improve human connections, relationships, and civilization. For Lawrence, emotional transcendence comes from realizing the other as subject. That other is confined to a machine-like act of creating a gendered persona while refusing to see men and women as similar. What Lawrence terms "will" is the limitation created by idealized, ideologically constructed roles that men and women must shore up against. Lisa Rado explores the "third sex" as part of the modernist construction of the imagination through an androgynous sublime. She focuses her study on how these writers use imagination to construct an "androgyne" figure that gives them the cultural authority to create. For Rado, the "androgyne imagination" is the use of a muse-like androgynous figure as "a solution to male modernists searching for a means to restore their artistic prerogative while it provided female modernists with a way to transform their position from aesthetic objects to active creators" (Rado 13). This imagination should create a "supreme experience of empowerment" but "results into feelings of despair, panic, collapse, and engulfment" (Rado 22). These feelings show a failed sublime moment as a crisis of literary authority. Lawrence, though, allows for no "third sex," and as a 
result, his sublime experience reveals a subject/subject interaction that rewrites the subject/object discourse of the sublime. The sublime here realizes that the "object" is a fellow subject, producing a transcendent moment of emotional connection that differs from the ego-based Kantian formulation that relies on reason.

Edmund Burke first theorizes the sublime in a subject/object discourse on aesthetics and Kant expands this approach with an emphasis on the subject rather than the object. Kant uses the same empirical assessments as Burke for his discussion of the sublime object: darkness, infinity, the failure of language, greatness, etc... These are all objects that convey something unexpected and enormous and which also bring a feeling of terror that must be subjugated through the interaction of the imagination and reason. Kant grounds his aesthetic theory in aesthetic judgment. ${ }^{7}$ For beauty, judgments are based on form and proportion; they are quantified and can fall under the rubric of Taste. There are quantifiable components that society indicates are beautiful because they are pleasing. The sublime, though, is more subjective, and Kant discusses it in terms of "emotion" or "feeling": "Not all aesthetic judgments are judgments of taste, which as such refer to the beautiful; but some of them arise from an intellectual feeling and as such refer to the sublime" (Critique of Judgment 32, bold my emphasis). Here, judgment is made possible through reason. As Andrew Bowie writes of Kant's sublime: "The sublime cannot, therefore, rely on the pleasure generated in judgment's sense of the purposiveness of the natural, or aesthetic object. As such, the sublime is only significant to the extent to which it reveals a purposiveness in ourselves with regard to our capacity to transcend nature by reason" (43). For Kant, the sublime is the realization of reason through transcendence; it is an overcoming of the imagination that provokes an understanding of terror into a self-affirming act of the mind's cognitive abilities. It is how a subject uses reason to realize the capacity of the mind to imagine. 
Lawrence directly confronts Kant as part of an Enlightenment project that prioritized reason and knowledge over emotion. Lawrence repeatedly connects Kant to a patriarchal philosophical tradition that led to the crisis of modernism in the early twentieth century, a crisis from society's emphasis on Knowledge, Reason, and Idealism dating to the eighteenth century. In "Books," Lawrence writes that thought is "an adventure of the whole man not merely of his wits. That is why one cannot quite believe in Kant, or Spinoza. Kant thought with his head and his spirit, but he never thought with his blood" (198). Lawrence directly connects blood with feeling, emotion, and sensuality, so his disavowal of Kant's rationality and emphasis on mental faculties is in favor of human emotion. ${ }^{8}$ Lawrence makes a similar move in "On Taking the Next Step" when he ponders the "ends" resultant in modernity's idea of being on the brink or the edge: "The end of idealism, the end of idealistic ethic. The end of Plato and Kant, as well as of Jesus. The end of science, as an absolute knowledge. The end of the absolute power of the Word. The end, the end, the end" (387). What Lawrence documents as the crisis of modernity is the collapse of social and ideological structures like philosophy, science, and language. All of the ideological structures he lists are complicit in the construction of a patriarchal society and continue to construct their discourse on the sacrifice or oppression of the feminine. ${ }^{9}$ As the essay continues, Lawrence makes it clear that brinks or borders are necessary in order to transcend ideological structures (“On Taking the Next Step" 387-388).

In Fantasia and the Unconscious, Lawrence laments a strict gender division caused by discourses like philosophy and religion:

[N]o man is a blooming marvel for twenty-four hours a day. Jesus or Napoleon or any other of them ought to have been man enough to be able to come home at tea-time and put his slippers on and sit under the spell of his wife. For there you are, the woman has 
her world, her positivity: the world of love, of emotion, of sympathy. And it behooves every man in his hour to take off his shoes and relax and give himself up to his woman and her world. Not to give up his purpose. But to give up himself for a time to her who is his mate. And so it is one detests the clockwork Kant, and the petit-bourgeois Napoleon divorcing his Josephine for a Hapsburg — or even Jesus, with his "Woman, what have I to do with thee?" He might have added "just now." They were all failure.

The allusions to Napoleon and Jesus are complicit with a gendered ideological structure that connects with the reasoning, "clockwork" of Kant. Lawrence posits a theory of sexual difference here, but at the same time, he sees a "give and take" that allows men and women to establish human connection. Although he does link woman to the home, Lawrence also couples woman to what he perceives as the best human quality: emotion. Again, we have a contradictory Lawrence who reinforces an association of women with the domestic sphere while at the same time insisting that men belong in that sphere in order to connect with their wives and encourage the emotional quality of the feminine. Lawrence employs the nineteenth century concept of the separate spheres; however, he ultimately suggests that men belong in the private rather than public sphere. ${ }^{10}$ Lawrence shows a trend in his thinking of the necessity of men becoming more involved in the domestic sphere, including more active fathering.

Lawrence returns to Kant's "reason" as the root of the problems of modern civilization, because the idea of reason is rooted in a discourse that suppresses the emotional. Kant describes the sublime moment in terms of feeling and emotion, but he also suppresses the emotional in favor of cognitive ability represented through reason. In the Critique of Judgment, Kant repeatedly associates the sublime with emotion: "the feeling of the sublime" (98), the "feeling of 
momentary inhibition of the vital forces followed immediately by an outpouring of them that is stronger" (98), "a substrate that...makes us judge as sublime not so much the object as the mental attunement in which we find ourselves when we estimate the object" (112), or "the feeling of the sublime is a feeling of displeasure...but is at the same time also a pleasure" (114115). Again and again, Kant bases his estimation of the sublime first on feeling and on sensation, but he then objectifies that emotion through reason's interference by insisting on the sublime's relationship to cognition. Kant writes, "Hence sublimity is contained not in any thing of nature, but only in our mind, insofar as we can become conscious of our superiority to nature within us, and thereby also to nature outside us (as far as it influences us)" (Critique of Judgment 123). The sublime is connected to the mind, and for Kant, the highest faculty of the mind is reason, not emotion.

Lawrence rejects Kantian reason as it makes emotion an object of analysis for the mind, especially in the sublime experience. In essence, the modernist impulse to objectify emotion in poetry or critical writing on aesthetics follows from Kant's objectification of emotion through reason in his aesthetic theory. For instance, Kant writes of the complicated nature of emotion in distinguishing the beautiful from the sublime:

Emotion, a sensation where agreeableness is brought about only by means of a momentary inhibition of the vital force followed by a stronger outpouring of it, does not belong to beauty at all. But sublimity (with which the feeling of emotion is connected) requires a different standard of judging from the one that taste uses as a basis. Hence a pure judgment of taste has as its determining basis neither charm nor emotion, in other words, no sensation, which is [merely] the matter of an aesthetic judgment. (72) 
For Kant, a pure aesthetic judgment should not be emotional; however, a sublime response joins with emotion, which makes it more subjective. The modernist act of aesthetic judgment that collapses the sublime and ugly into the beautiful actually draws attention to the subjective nature of art while trying to maintain aesthetic disinterestedness. ${ }^{11}$ Kantian and modernist aesthetics favor judgment and reason as suppressing the emotional through the stance of disinterestedness. By explaining the sublime as an emotional experience yet favoring "reason," Kant actually makes emotion an object that reason must master. By making an emotional experience an object of analysis for the mind, Kant still maintains the same subject/object dynamic that Burke employs. Unlike Burke's use of physical object, Kant makes the object of the sublime a subject's emotions, and if we translate that into gendered terms, the discourse of the sublime relies on the objectification of the feminine. ${ }^{12}$ Lawrence insists on the importance of emotion to subjective experience but that formation is blocked by the reasoning abilities of the Cartesian subject. Although, as Anne Fernihough shows, Kantian aesthetics employs a subject-centered approach, Lawrence emphasizes a "subjectivist standpoint of traditional art theory" (1) that draws attention to the subject/object approach of Kant. Lawrence complicates the Kantian sublime by reconfiguring it as an intersubjective experience between parents in The Rainbow.

\section{Lawrence's Intersubjective Sublime in The Rainbow}

Birth is a central theme in The Rainbow, and as a result, it is often either explicitly or implicitly linked to the sublime, gender, and sexual difference. In the novel, birth functions much like death in the traditional sublime dynamic by conveying the infinite through the reproduction of the human race. Through birth, a mother or father must recognize the terror of the act itself as well as the pleasure that results from the mind's capacity to realize the scope of the human progress through generation. The mind conceptualizes the infinite through the 
production of the child, and it is here that Kant would say reason intervenes. For Lawrence, though, the mind is less important than the emotions, and through feeling, a character realizes a connection to generation and human beings. In addition, Lawrence also links birth metaphorically to a number of characters in the novel in order to mark a moment of awareness or epiphany; it also marks an emotional moment when one's feelings overcome rational thought. As a result, birth is key to the construction of the characters in the novel, because it provides a mythic connection with the past that is produced through emotion and connection. Rather than validating the ego or the individual mind, Lawrence shows the sublimity of human connection through feeling, which results in reciprocating emotions between characters. By contrasting a positive sublime in Tom and Lydia and a negative sublime in Will and Anna, Lawrence shows how history links to generation, and how generation is necessary to human community.

The Rainbow opens with detailed descriptions of land in an agricultural England and proceeds to connect this land with the generation of the Brangwen family through rather than despite sexual difference. In the opening pages, Lawrence lavishes description of the land on which the Brangwen farm is located, but at the same time, he contrasts this image with the highly ideological and institutionalized church that sits on a hill near the farm. As a result, the Brangwens' story is one about the growth and encroachment of "civilization" on an agricultural society. Beginning with the church and the farm, Lawrence sets human feeling and connection at odds with the institutionalized life that is fully realized through capitalism in the early twentieth century. One of the most important issues for this institutionalization is linked to gender and sexual difference, and as a result, women are paired with the heart of the Brangwen farm. They provide the hope of generation and the continuation of agricultural life; however, as society encroaches on this life, social roles become too constricting for both the Brangwen men 
and women. Because of this connection between land and family, the novel opens with lavish description of the Brangwens' connection to land through generation:

They felt the rush of the sap in spring, they knew the wave which cannot halt, but every year throws forward the seed to begetting, and falling back, leaves the young-born on the earth...Their life and inter-relations were such; feeling the pulse and body of the soil, that opened to their furrow for the grain, and clung to their feet with a weight that pulled like desire, lying hard and unresponsive when the crops were to be shorn away. (The Rainbow 9-10)

The language of this passage consistently places nature as a process of birth and rebirth that is linked with sexuality and desire. As John Worthen has commented, Lawrence is one of the most bodily of writers, and the importance of the body, both reproductive and desiring, is pivotal to the development of Lawrence's theme of generation in the novel (Outsider xxii). Through the process of reproduction and an implicit invocation of biological sexual difference, human connection and generation is made possible.

Despite attempting to reconsider gender in Lawrence's text, I cannot deny the masculinist tone that also exists in the opening passages. In his discussion of sexual difference, Lawrence shows men contentedly working away on their farms with no need of formal knowledge, while the women, confined to their houses, keep looking to civilization (the village and the road) (The Rainbow 10-11). As a result, Lawrence implies that women are in some way responsible for the plight of current civilization, because "[s]he craved to know. She craved to achieve this higher being, if not in herself, then in her children" (The Rainbow 11). At the same time, Lawrence sees women as confined to the home, and by engaging with the home rather than the land, they are forced to look for knowledge as a way outside of the domestic. Lawrence writes that "[t]he 
women were different" (The Rainbow 10), because they are confined to "the house where the women moved about with surety" (10) and are always "[1] ooking out, as she must, from the front of her house towards the activity of man in the world at large" (11). Consistently, the woman gazes from inside the domestic sphere as she submits to her domestic role that allows men to sit "by the fire and their brains were inert" (10). While he may fault women for their influence over their children in the production of the knowledge-seeking modern subject, Lawrence also recognizes the larger impact of constricting social roles in producing the woman who wants to know (The Rainbow 11). Considering that at the time of writing The Rainbow, Lawrence wanted the Women's Rights movement to influence men to adopt more feminine and emotional behavior rather than women adopting masculine behavior, which contributed to the crisis of modernism, the opening of The Rainbow reflects an approach to women's empowerment that will ultimately fail because it conforms to the masculine, intellectual world. This struggle between public and private plays out in the novel as Ursula, the final descendent of the Brangwens in the novel, becomes calloused through entering the male workforce and adapting herself to it. From the start of the novel, Lawrence's position on gender is contradictory and paradoxical, and yet, he recognizes social systems that construct gender roles even while situating his work in sexual difference.

Dissatisfaction with knowledge and idealization emerges in the novel through the figure of Tom Brangwen. Lawrence's parallels Tom's dissatisfaction with "education" with his inability to connect with women. Lawrence conveys this incompatibility through the image of women as "foreign" to men throughout the novel, and in the case of Tom, it is even more significant as his eventual wife, Lydia Lensky, appeals to him due to her ethnic foreignness. At the same time, Tom resists the masculinization that he sees formal knowledge and the education 
system as trying to instill in him (The Rainbow 18). He prefers the agricultural work of the farm to the routinized knowledge conveyed through formal schooling; however, Tom enjoys literature-especially the British Romantic poets like P.B. Shelley (The Rainbow 17). Tom's connection to these writers reflects his own love of nature on the Brangwen farm.

Tom feels uncomfortable seeing women as sexual objects, which reveals his awkwardness with heterosexual masculinity and patriarchy. Although his first sexual encounter is with a prostitute, Tom immediately rejects this approach to women, because it inspires no passion and makes him feel disconnected. Tom feels lost as a result of this encounter: "He did not know what to feel. There was a slight wonder, a pang of anger, of disappointment, a first taste of ash and of cold fear lest this was all that would happen, lest his relations with woman were going to be no more than this nothingness" (The Rainbow 20). Tom's disappointment stems from his inability to form a connection or a bond of love in the sexual act, and the prostitute emphasizes a failure to access the passion he associates with the farm. As a result of this encounter, Tom reflects on his idealized woman, which mimics the social constructions of the time:

The woman was the symbol for that further life which comprised religion and love and morality. The men placed in her hands their own conscience, they said to her "Be my conscience-keeper, be the angel at the doorway guarding my outgoing and my incoming." And the woman fulfilled her trust, the men rested implicitly in her, receiving her praise or her blame with pleasure or anger, rebelling and storming, but never for a moment really escaping in their own souls from her prerogative. They depended on her for their stability. Without her, they would have felt like straws in the wind, to be blown hither 
and thither at random. She was the anchor and the security, she was the restraining hand of God, at times highly to be execrated. (The Rainbow 20)

For Tom, woman represents the domestic Angel common in Victorian discourse, revealing woman as an important figure. In this construction, though, he sees woman as validating the masculine self in a typical subject/object interaction. In sex, he realizes the inadequacy of objectifying women, but in terms of symbolic status, Tom continues to objectify woman in idealized terms.

When he meets Lydia, Tom finds a woman who is the "embodiment of all his inarticulate, powerful religious impulses" (The Rainbow 32), but as Lydia fails to match his ideal, Tom must confront his own assumptions about women and sexuality. Lydia is an older, Polish woman with a child from a previous marriage, and because she is foreign in multiple ways (race, gender, parenthood), Tom finds her difference encouraging for love and passion. After seeing Lydia, Tom thinks, "He felt also a curious certainty about her, as if she were destined to him. It was to him a profound satisfaction that she was a foreigner" (The Rainbow 32). Immediately, Tom feels an attraction to Lydia due in part to her foreignness and her difference, but at the same time: "He dared scarcely think of the woman. He was afraid. Only all the time he was aware of her presence not far off, he lived in her. But he dared not know her, even acquaint himself with her by thinking of her" (The Rainbow 32). From their first encounter, Tom feels fear, although not quite terror, but at the same time, he refuses to think of her, creating an emotional distance that must eventually be transcended. In this way, the relationship is initially situated as a subject/object interaction, but as the emotional distance increases as a result of the pressures of expected social roles in marriage, the dynamic collapses in favor of a subject/subject connection. 
Lydia's refusal to conform to social expectations later allows transcendence in her relationship with Tom. In addition to her race, Lydia's foreignness is marked by her ignorance of social customs. When she runs out of butter, Lydia ventures to Tom's farm in order to ask to borrow some. When Tom answers the door, Lydia commits the social faux pas of not awaiting an invitation inside, and instead, she walks immediately in the door, which "startled him [Tom]. It was the custom for everybody to wait on the doorstep till asked inside" (The Rainbow 34). As Tom's servant comes into the kitchen, the narrative perspective shifts to that of Tilly, who sees Lydia's asking for butter as improper: "She could not understand the entire lack of manners, was slightly puzzled" (The Rainbow 35). From her introduction in the novel, Lydia's position as an outsider shows her as existing outside social rules, which in turn, allows the marriage of Tom and Lydia to develop outside of expected gender roles.

Once married, Lydia refuses to play the submissive role of housewife for Tom as a result of her experiences from her first marriage; her denial of these roles creates an emotional distance between herself and Tom that is necessary to deconstruct Tom's image of idealized woman that is similar to the Angel of the House. During her first marriage, Lydia learns nursing as a way to emancipate herself from the home (The Rainbow 49), but she must give up this career in preference to her husband's and as a result of motherhood. She must engage in the idealized role of Victorian women, but "Lydia, tempered by her German blood, coming from a different family, was obliterated, carried along in her husband's emphasis of declaration, and his whirl of patriotism....And Lydia, as if drugged, followed him like a shadow, serving, echoing" (The Rainbow 49). In this first marriage, Lydia plays the role of the proper housewife, and as a result, she is erased. 
Later in the novel, Lydia discusses her first marriage with her granddaughter, Ursula, and she recognizes herself as an object or a slave to her husband: "He incorporated her in his ideas as if she were not a person herself, as if she were just his aide-de-camp, or part of his baggage, or one among his surgical appliances. Still she resented it" (The Rainbow 238). As the passage continues, Lydia realizes her dissolution: "By his acceptance of her self-subordination, he exhausted the feeling in her" (The Rainbow 239). Through patriarchal oppression, Lydia feels a loss of selfhood and the denial of her desires. Lydia conveys her husband's failing through an association with work, and by focusing on the mind more than the body or emotion, Paul fails. After Paul's death, Lydia "could not subscribe [to failure]. He had failed, everything had failed, yet behind the failure was the unyielding passion of life. The individual effort might fail, but not the human joy. She belonged to the human joy" (The Rainbow 239). Ultimately, Lydia connects herself with emotion rather than with work or knowledge; she realizes the importance of connection in relationships between men and women that creates an emotional knowledge of the other's desires. This is exactly what Tom provides: "The other [husband, Tom] she loved out of fulfillment, because he was good and had given her being, because he had served her honorably, and become her man, one with her" (The Rainbow 240); whereas, "During her first marriage, she had not existed, except through him, he was the substance and she the shadow running at his feet. She was very glad she had come to her own self. She was grateful to Brangwen" (The Rainbow 240). Ultimately, Lydia realizes her own self through a connection with Tom, but this results more from her previous experiences with her first husband, which made her realize that idealized gender and marital roles create "foreignness" in the self.

Consistently, the novel shows the unsurpassable gulf between men and women as created by idealized social roles that make connection difficult if not impossible. Still, these roles create 
the boundaries necessary to promote emotional distance and offer the possibility of transcendence from foreignness or loneliness into connection. In order to engage in this connection, the characters must participate in the act of generation, which arises through passion and emotion. Lydia and Tom undergo the sublime experience during the birth of their first son, and it is not until they recognize their connection with generation that an intersubjective sublime experience is possible. When Lydia begins her labor, Tom separates his mind and body, which considering the gendered nature of these two terms in discourse, shows a masculine and feminine approach to childbirth. His mind wants to disconnect and maintain a separation of masculine and feminine, but his body, his emotion seeks a connection with his wife:

Elsewhere, fundamental, he was with his wife in labour, the child was being brought forth out of their one flesh. He and she, one flesh, out of which life must be put forth. The rent was not in his body, but it was of his body. On her the blows fell, but the quiver ran through him, to his last fibre. She must be torn asunder for life to come forth, yet still they were one flesh, and still, from further back, the life came out of him to her, and still he was the unbroken that has the broken rock in its arms, their flesh was one rock from which the life gushed, out of her who was smitten and rent, from him who quivered and yielded. (The Rainbow 71)

Lawrence's displays a bodily, emotional feeling between Lydia and Tom during childbirth that shows connection through the production of an actual child. Tom's empathic response casts him as a feminine character who attempts to understand the sacrifices of his wife for the child.

Unable to maintain the emotional connection, Tom goes to the barn and becomes terrified of the birth experience, which marks woman as different from man: "The moaning of the woman. What an uncanny sound! It was not human—at least to a man" (The Rainbow 77). As 
the passage continues, Tom goes to see his wife and the image of her as inhuman continues: "She was beautiful to him—-but it was not human. He had a dread of her as she lay there. What had she to do with him? She was other than himself" (The Rainbow 77). In this moment, where the literal fact of childbirth marks women as biologically different from men, Tom realizes the importance of that difference, that otherness. Slowly, his emotional response of terror and dread is tinged with pleasure: "But his heart in torture was at peace, his bowels were glad" (The Rainbow 77). Here, Lawrence describes the traditional Kantian sublime moment where one who is faced with the infinite (in the case of generation) is filled with terror and yet also pleasure. The pleasure arises as Tom uses his mind to reinforce the idea of the woman as other; he grasps the magnitude of generation and takes pleasure in his realization of that in terms of gender difference. Tom reconsiders this subject/object Kantian sublime experience as Lydia makes him confront both difference and distance in order to recognize her desire.

By stressing biological difference though childbirth, Lawrence creates an emotional distance between Lydia and Tom, and both Lydia and Tom fail to express this difference through language. To achieve an intersubjective sublime moment, Lydia and Tom must first recognize idealized, symbolic gender roles that have been constructed in Victorian society through marriage and parenthood. Through her first marriage, Lydia has already experienced the life of the Angel and the Patriarch. Tom, who refuses typical masculinity through education and sexuality and who embraces fatherhood as an emotional rather than law-enforcing role with his adopted child, Anna, rejects the patriarchal role Victorian society dictates. In addition, his insistence on remaining a farmer rather than pursuing knowledge and a (more than likely capitalist) career shows that Tom, like Lydia, is already engaged in understanding his own version of masculinity that does not erase his selfhood. Both characters have already 
deconstructed their own marriage roles, but in order to connect with each other, they must recognize the construction of those roles in the "other" and realize that they create the alienated modern subject.

Tom and Lydia must realize that both the Angel and the Patriarch are socially constructed symbols that promote discontent in the modern subject. In order for transcendence to happen, they must first fulfill and live those roles. As the Lydia and Tom section of the novel comes to a close, Tom believes that Lydia no longer wants him, both emotionally and sexually, as a result of her childbirth. He even contemplates having an affair, which Lydia intuits. In the scene where Lydia confronts Tom about the possibility of another woman, silence reveals what language cannot say-that Tom and Lydia both participate in an intersubjective sublime moment as they both realize the isolation and alienation of the "other" when forced to participate in socially constructed gender roles. In confronting Tom about why he no longer wants her, Lydia says, "I want you to know there is somebody there besides yourself" (The Rainbow 89). In making this statement, Lydia confronts Tom about treating her as an object: "To you I am nothing —it is like cattle_or nothing" (The Rainbow 89). And interestingly, Tom responds in the same way, "You make me feel as if I was nothing" (The Rainbow 89). Here is the crux of the problem: ideological constructions of gender require one person to treat another as an object, as an emotional nothing, and as a result, these gender roles come in conflict with emotional and subjective experience. Finally, Tom looks on Lydia and is filled with terror: "It was to him terrible, how she could be transfigured" (The Rainbow 89), and as Lydia embraces Tom, the narrator writes:

The fear was like bliss in his heart. He looked down. Her face was shining, her eyes were full of light, she was awful... She was the awful unknown. He bent down to her, 
suffering, unable to let go, unable to let himself go, yet drawn, driven. She was now transfigured, she was wonderful, beyond him... She waited for him to meet her, not to bow before her, and serve her. She wanted his active participation, not his submission. (The Rainbow 89-90)

In this passage, the terrible becomes pleasurable as "bliss." The unknown, which is a key factor of the sublime, is invoked and described as "awful," which reflects Tom's feeling of awe. The language here plays on descriptions used in the Kantian sublime, and finally, the moment of cognition occurs; however, it is through emotion and not reason.

Ultimately, the sublime intersubjective moment is realized by Tom and Lydia as they recognize the desires and needs of the other. The narrator comments,

They had passed through the doorway into the further space, where movement was so big, that it contained bonds and constraints and labours, and still was complete liberty. She was the doorway to him, he to her. At last they had thrown open the doors, each to the other, and had stood in the doorways facing each other, whilst the light flooded out from behind on to each of their faces, it was the transfiguration, the glorification, the admission. (The Rainbow 90-91)

Finally each recognizes the other and works with the other through an emotional connection. Tom "knew her, he knew her meaning, without understanding" (The Rainbow 91). In this moment, Lawrence implies that one can grasp the infinite through emotion rather than through reason. The sublime is a subject/subject formation that allows both Tom and Lydia to realize the limitations of constructed identities and transcend those identities in order to escape the alienation of the modern subject. The final transcendent image of the section, conveys not a rainbow but an arch between Lydia and Tom under which their child Anna plays: "She [Anna] 
was no more called upon to uphold with her childish might the broken end of the arch. Her father and her mother now met to the span of the heavens, and she, the child, was free to play in the space beneath, between" (The Rainbow 91). With this final image, an intersubjective sublime experience emerges as positive; however, Anna is now free to pursue her own wants and desires regardless of her parents. Anna more fully embraces Victorian constructions of gender and uses them as weapon that keeps herself apart from her husband, Will, and Will does the same. As a result, Anna's freedom gives her none of the satisfaction of her parents' relationship. Anna's sense of self develops from Tom and Lydia's relationship, but she is always concerned with her position and status-particularly in terms of class and gender. Anna is attracted to her mother's friend the Baron Skrebensky as a child, and her interest in him arises from his class position. As she gets older, the projection of a middle-class femininity is particularly important for adolescent Anna: "And at this period she was absorbed in becoming a young lady" (The Rainbow 94). Anna even goes to a ladies school in order to become a proper lady, but as she comes into contact with other young ladies, Anna finds that she cannot tolerate them, because they fail to live up to her idealized image of the "lady" (The Rainbow 94). From adolescence onward, Anna finds it hard to reconcile idealistic or symbolic images with lived life. For instance, Anna likes the image of ladies while she detests the girls training to become ladies at her school: "Still she thought the people she did not know were wonderful. Those she knew seemed always to be limiting her, tying her up in little falsities that irritated her beyond bearing" (The Rainbow 94). As a result, Anna retreats to her home world where she can maintain her idealized images without being confronted, because the Brangwens" "lives were too separate" (The Rainbow 94). Anna retreats into the world of Lydia and Tom with its disconnection from 
modern life; however, Anna must confront that world once she marries her cousin, Will, who represents the educated, progressive Victorian man.

From the beginning, Anna and Will's relationship is a struggle based on sexual difference - a point that critics like Elaine Showalter, Sandra Gilbert, and Susan Gubar have made. What these critics have failed to recognize is that during the early portion of Anna and Will's relationship the gendered binary of mind/body is inverted. ${ }^{13}$ During courtship and the early days of marriage, Anna and Will find connection through the sensual nature of Will's body. The sexualized object in this relationship is not the female but the male body and shows the masculine embracing emotion or the feminine: "Then to her, as she felt his young, tense figure with her hands, the bliss was intolerable, intolerable the sense that she possessed him. For his body was so keen and wonderful, it was the only reality in her world. In her world, there was this one tense, vivid body of a man....In him she touched the centre of reality. And they were together, he and she, at the heart of the secret" (The Rainbow 121). In this sexual awakening, for both Anna and Will, they connect in their early days of marriage, freeing themselves from a repressive society that rejects the bodily. This feeling does not last and as they relinquish the "honeymoon" phase of their marriage, Anna and Will begin to battle one another as their individual desires confront expected social norms. In particular, Will begins to become dissatisfied with Anna as she decides to play the role of the married lady and have a tea-party: "She wanted the dead world again — she wanted to walk on the outside once more. She was going to give a tea-party" (The Rainbow 140). Will finds solace in retreating to the domestic, and during this early phase of the marriage, he even partakes in domestic duties (i.e., cooking). Once she decides to conform to her expected social roles, Will sees Anna as a different, impersonal being: "He wanted her back. Dread and desire for her to stay with him and shame at 
his own dependence on her drove him to anger...All the love, the magnificent new order was going to be lost, she would forfeit it all for the outside things" (The Rainbow 141). The narrator appears to cast Anna at fault for their resultant battles, but it is social norms and expectations that cause Anna to enact this role. Like with Lydia and Tom, gendered social expectations cause the impassable divide of sexual difference that centers on childbirth.

Anna eventually becomes pregnant, and she embraces motherhood as a connection to generation and larger, transcendent forces. Anna's interest in the mother figure is defined through the symbolic depiction of the Madonna in Christianity. As an adolescent, Anna finds solace in repeating the phrases from the "Ave Maria" that refer to motherhood and the womb as a mystic space: 'It irritated her to say 'Dominus tecum,' or 'benedicta tu in mulieribus.' She loved the mystic words 'Ave Maria, Sancta Maria': she was moved by 'benedictus fructus ventris tui Jesus,' and by 'nunc et in hora mortis nostrae"' (The Rainbow 98). The passages from the "Ave Maria" that Anna connects with concern the larger process of generation, linking both life and death to the infinite and the beyond. Anna begins to see her body as connected to a larger, life-giving process.

Through motherhood, Anna confirms her difference from Will, and as a result, he finds her pregnant body repulsive. In an often cited scene, a pregnant Anna dances naked in her room as she performs a spiritual dance to the infinite that contradicts the bodily. One day, Will interrupts Anna's dancing and becomes an unwanted voyeur on the scene:

And she lifted her hands and danced again, to annul him, the light glanced on her knees as she made her slow, fine movements down the far side of the room, across the firelight. He stood away near the door in blackness of shadow, watching transfixed. And with slow, heavy movements, she swayed backwards and forwards, like a full ear of corn, 
pale in the dusky afternoon, threading before the firelight, dancing his non-existence, dancing herself to the Lord, to exultation.

He watched, and his soul burned in him. He turned aside, he could not look, it hurt his eyes. Her fine limbs lifted and lifted, her hair was sticking out all fierce, and her belly, big, strange, terrifying, uplifted to the Lord. Her face was rapt and beautiful, she danced exulting before her Lord, and knew no man....

"That isn't dancing," he said harshly. "What do you want to do that for?" "I don’t do it for you," she said, “you go away." (The Rainbow 171)

In a compelling reading of this scene, Stephen P. Clifford discusses a critical misreading by Peter Balbert of Anna as aggressively antagonizing Will (Balbert 71). Clifford notes that this passage is in fact narrated through Will's perspective as a voyeur who interrupts the scene (68). Will in fact projects his reading of Anna onto the text, but it does not reflect Anna's actual desire. He reads her as dancing for a Lord that is not him, and he sees her as dancing to defy him. Anna's comment at the end is very revealing, "I don't do it for you" (The Rainbow 171). Through motherhood, Will reads Anna as the infinite, a terrifying and threatening force to his masculine position as husband. As a result, many of the passages in the Anna/Will section of the novel that describe their struggles are Will's projections of his thoughts onto Anna. If we consider this easily shifting narrative voice, Lawrence actually represents masculinity as part of a larger social fear that understands the feminine as threatening. This is very different from Lawrence representing the feminine as threatening. Will's "fear" of the infinite and the feminine are what deny any possibility of sublimity in his interactions with Anna. Anna is in every manner a sublime object, representing the infinite, but Will is literally terrified of her and her body. As a result, Will cannot distance himself from Anna emotionally, and the terror consumes him. As 
Kant discusses, the presence of a real terror or threat cannot produce the sublime moment, because there is not the distance necessary for the mind to realize its cognitive abilities

The reading of the maternal body as threatening is even further complicated when we consider Will's love of architecture, particularly church architecture. Once Anna and Will are married, Tom purchases the cottage beside the church for them, and Will becomes the caretaker of the church. Masako Hirai argues that the church reflects the sublime aligned with Ruskin's aesthetic writings on architecture. Part of her argument connects to the images of generativity and physical labor that appear in the early part of the novel (Hirai 205). In the first part of her essay, Masako links generativity and labor to the sublime (a point with which I agree). Masako correctly connects the church to the womb, but in doing so, she reads the womb as a particular passion for Will (Hirai 210). As the previous scene with Anna shows, Will finds the womb a threatening and terrifying space, so Will's association of the cathedral with the womb is a paradoxical one. On taking Anna to see the cathedral, Will declares the cathedral a "she"-a gendering which annoys Anna. At the church, Will thinks, "In a little ecstasy he found himself in the porch, on the brink of the unrevealed. He looked up to the lovely unfolding of the stone. He was to pass within the perfect womb" (The Rainbow 186). Once in the church, both Anna and Will are overcome with the awe, and Will connects the church to the cycle of life and death as well as immorality (The Rainbow 187). As he leaves the cathedral, Will again associates the church with the womb: "Out of the doors of the womb he had come, putting aside the wings of the womb and proceeding into the light. Through daylight and day-after-day he had come, knowledge after knowledge and experience after experience, remembering the darkness of the womb, having prescience of the darkness after death" (The Rainbow 187). Lawrence directly 
connects birth with death in this scene and links birth to a discourse of the sublime that has largely ignored it.

Will's love of the church as a womb and hatred of Anna's womb is particularly paradoxical, but the womb he loves is created through man and is connected to a patriarchal Christian structure that depends on the sacrifice of the feminine. Will worships a womb not from the natural but the man-made world, and as a result, he becomes further disconnected from the generation that the Brangwen farm represents. Anna's resentment of Will's declaration of the cathedral as a "she" shows the gendered language of patriarchal discourse that often objectifies the feminine. Will loves the womb of the cathedral, because it is a quantifiable object that he can take stock of in an objective, aesthetic sense. He hates Anna's womb because he cannot understand her own wants and desires as a subject. Thus, when she dances pregnant and naked for her own reasons and not for Will, Will objectifies Anna as other through fear. Anna's insistence on her dance denies Will's attempts at objectification and demands that Will recognize her as subject. Will, with his ingrained aesthetic and religious discourse, is unable to break away from a subject/object dynamic. The end result is the absolute division between the sexes, and Will's "will" is the focus of Anna's commentary. The "will" Anna constantly fights is Will's insistence on considering her as an object rather than a subject.

Peter Balbert and Andrew Harrison explore Will's dissatisfaction as a result of his "will," which they relate to aggressive masculinity; however, this reading changes if, as Carl Krockel insists, Lawrence's definition of "will” is considered, especially as relates to German philosophy (Krockel 16). For Lawrence, "will" is a component of the modern subject that results from a society focused on idealism, especially as regards "love." "Will" becomes the battle of the individual or self against larger ideological forces that try to impose subject positions on people 
as a result of their sex. ${ }^{14}$ As a result, Will's use of his "will" to combat Anna throughout the novel references a gender struggle that is created by the maintenance of strict gender roles in marriage and family. In fact, the strongest description of Will's "will" occurs directly after Anna's dancing: "Gradually, she realized that her life, her freedom, was sinking under the silent grip of his physical will. He wanted her in his power....At length she realized that her sleep was a long ache and a weariness and exhaustion, because of his will fastened upon her" (The Rainbow 172). Like the dancing passage, discussions of Will's "will" are told through Anna's perspective. She perceives Will as battling her with his "will," but the narrator rarely shifts into discussions of Will's "will" from his perspective. Like Will does to her, Anna reads Will as a threat who is trying to consume her. If we consider the shifting narrative voices in these passages, Lawrence shows how the battle of the sexes occurs through a constant misreading of the other through one's fears.

This depiction of fear in The Rainbow also corresponds with Lawrence's perspective on fear in Fantasia and the Unconscious: "Every desire has its corresponding fear that the desire shall not be fulfilled. It is fear which forms an arrest-point in the psyche, hence an image" (Fantasia and the Unconscious 182). Fear creates a symbolic image, particularly a repressed image from the unconscious, and the battle between Will and Anna in The Rainbow shows how fear is the basis for social constructions of otherness. As Freud's psychoanalysis shows, the modern subject is one who represses desire as a result of fear, and in this respect, the idealized Victorian subjects of the Angel and the Patriarch represent a fear of the "other." As these roles become social norms that are cited in the construction of gendered identity, the Victorian subject creates bipolar categorizations that must be at odds with one another. As a result, instead of 
confronting and transcending their fears, Anna and Will retreat into accepted gender roles which they justify through their constant readings of the other's aggressive attitudes.

As the Will and Anna section of The Rainbow comes to an end, the reader sees Anna as the Angel of the House, supreme mother, and Will as the bread-winning Patriarch, ejected from the domestic sphere. As time passes, Anna is described as "subject to him [Will] as to the Angel of the Presence. She waited upon him and heard his will, and she trembled in his service" (The Rainbow 158). Anna is the submissive, sacrificing Angel who is subject to her husband's power. Will, though, sees Anna as antagonistic towards his role as patriarch:

He felt, somewhere, that she did not respect him. She only respected him as far as he was related to herself. For what he was, beyond her, she had no care. She did not care for what he represented in himself...She did no service to his work as a lace-designer, nor to himself as bread-winner. Because he went down to the office and worked every daythat entitled him to no respect or regard from her, he knew. (The Rainbow 159)

The divide between Anna and Will widens as they fulfill their supposed social roles. Anna resents Will as the patriarch who must consume her while he resents her for not acknowledging his work in the public sphere. The tension between these two symbolic figures shows in the relationship between Anna and Will, characters who often fail to live up to these idealistically gendered images. The unquestioning submission to these roles makes an intersubjective sublime experience between Anna and Will impossible. As the novel progresses to Ursula, child of the third generation of Brangwens, the sublime intersubjective relationship of Lydia and Tom is preferable to that of Anna and Will, because it reveals the constrictive nature of gender and marriage roles, which set mother and father, wife and husband, man and woman apart. 
Because of psychoanalysis and rapidly changing gender attitudes, early twentieth century subjects must confront their own fears and desires in conjunction with the idealized roles created by the previous, Victorian generation. Ursula represents the in-between position of the modern subject, and although the end of the novel gives no definitive sublime moment, it portrays a hopefulness of that sublime intersubjective moment through human connection in Ursula's future. Ideally, Ursula would synthesize the Lydia/Tom and Anna/Will relationships into a new form; however, she becomes the isolated, modern subject who questions gendered social roles. Ursula engages in a lesbian relationship with Winifred Inger and a sexually active heterosexual relationship with Anton Skrebensky-both outside of marriage. Although her relationship with Anton stops as a result of his going away to the Boer War, toward the end of the novel, Anton returns and asks Ursula to marry him. After they become engaged, they go away together for a weekend, which requires Ursula to buy a fake wedding ring in order to make the relationship appear socially respectable. The couple plays at being husband and wife, revealing that even marriage roles are constructed in terms of gender. Eventually, Ursula breaks off the relationship, and Anton leaves for India. After he is gone, Ursula finds that she is pregnant. As a result of finding out her condition, Ursula retreats to nature where she encounters horses, a symbol of masculine "will" to Lawrence. By confronting an aggressively masculine will represented through the horses, Ursula becomes ill and as a result loses her baby. Although, as Peter Balbert has argued, this scene could be read as Ursula preparing for her ideal marriage partner, which is revealed to be Rupert Birkin in the sequel, Women in Love, I find this a rather simplistic reading of the end of the novel. Ursula's miscarriage results from her inability to connect with Anton, and the reason she cannot connect with him is that he wants her to enact a traditionally feminine role as subservient wife. 
Ursula's miscarriage is not a punishment but the natural course of attempts at generation that do not realize the importance of sexual difference in the development of human connection. As the novel ends, Ursula sees the rainbow, the same arch structure that is invoked in the intersubjective sublime relationship between Lydia and Tom:

And the rainbow stood on the earth. She knew that the sordid people who crept hardscaled and separate on the face of the world's corruption were still living, that the rainbow was arched in their blood and would quiver to life in their spirit, that they would cast off their horny covering of disintegration, that new, clean, naked bodies would issue to a new germination, to a new growth, rising to the light and the wind and the clean rain of heaven. She saw in the rainbow the earth's new architecture, the old, brittle corruption of houses and factories swept away, the world built up in a living fabric of Truth, fitting to the over-arching heaven. (The Rainbow 458-459)

The final image of the novel is one of human connection where the ideological structures like patriarchy and capitalism are erased as a result of a larger, transcendent realization of subjectivity. The final image is one of generation where a return to the old, transcendent relationship of the Brangwen farm along with a realization of the confining nature of symbolic social roles results in an erasure of the factory, the image of civilization and modernization, and the house, the domestic space where Victorian gender roles ultimately battled, and as Will and Anna show, ultimately resulted in Ursula, the lost, alienated, fragmented, modern subject. Ursula's miscarriage marks a rejection of her parents' social and gender roles in favor of a more fluid understanding of gender and sexuality that ultimately results in human connection and generation - a birth that transcends modernist subjectivity. 


\section{Chapter 5}

"What is R?": Mrs. Ramsay as Feminism's Sublime Object in To the Lighthouse

It is a truth universally acknowledged that Virginia Woolf's Mr. and Mrs. Ramsay are meant to represent the ideological roles of Patriarch and Angel in the House in To the Lighthouse. In particular, Mrs. Ramsay is viewed as an ideal Victorian woman or the perfect domestic goddess. ${ }^{1}$ Ellen Bayuk Rosenman has recently returned to Mrs. Ramsay as a domestic goddess in order to reread her as a redeeming figure. Over the past forty years, literary criticism

firmly establishes the Victorian ideological positioning of both Mr. and Mrs. Ramsay. ${ }^{2}$ In the past ten years, Emily Blair and Steve Ellis question feminist critiques that insist on Woolf's need to kill off the Angel in the House in favor of more nuanced interpretations of the mother as a necessary figure for Woolf's understanding of the domestic sphere and the Victorian era. Adding to this line of criticism, I explore Mrs. Ramsay as a redeeming Victorian figure in Woolf's novels who actually reveals the desires of the mother despite readings of her as a flat, Victorian mother character. Even though Woolf insists that writing To the Lighthouse allowed her to come to terms with her feelings for her mother, ${ }^{3}$ critical interpretations that insist on Lily as a surrogate daughter (because she is an artist like Woolf) ignore the complicated relationship between aesthetics and subjectivity in the novel. ${ }^{4}$ In this novel, only Mrs. Ramsay and Lily Briscoe experience sublimity via human connection; however, in order for sublimity to occur, the same subject/object dynamics expected in the aesthetic distancing in the creation of art show Woolf's less progressive ideas regarding the possibility of intersubjective relationships between men and women. By linking Mrs. Ramsay with the Angel of the House figure, especially through the aesthetics of beauty, Woolf ultimately undermines a simple assessment of Mrs. Ramsay as only a domestic goddess and beautiful object. Lily's anger toward and interest in Mrs. Ramsay suggests a conflict between Mrs. Ramsay's lived experiences and the cultural 
expectations from those who surround her. Lily actually exposes many of Mrs. Ramsay's desires and reveals that the mother is haunted by Victorian gender expectations. For Woolf, gendered ideological roles always separate men and women. Unlike D.H. Lawrence, E.M. Forster, and William Faulkner, Woolf maintains the subject/object dynamic necessary for the construction of the traditional sublime. The subject/subject dynamic only occurs between Mrs. Ramsay and Lily Briscoe who, as women, inhabit similar subject positions regardless of generational conflict, but this interaction reveals Woolf's feminist politics. Ultimately, the novel shows that modern women's conflict is not with "real" mothers but with the trapping of the Angel in the House and its imposition of strict Victorian gender roles.

I connect Woolf's exploration of aesthetics through the painter, Lily, to the traditional aesthetic concept of the sublime. Complicating approaches to intersubjectivity and the sublime that rely on an "object," I argue that Woolf creates a transcendent, intersubjective experience between women in order to explore the possibility of a feminist future by coming to terms with the women who participated in a patriarchal past. Considering her feminist politics, Woolf's emphasis on intersubjectivity between women reconciles the drastic shift in women's roles and personal relationships from the Victorian time period to the early twentieth century. More specifically, Woolf promotes the need for an intersubjective connection between Victorian women who (whether intentionally or not) promoted patriarchy and modern women who try to recognize and confront patriarchal oppression. For Woolf's feminist politics to work, modern women (like Lily) must confront and understand the domestic through the Victorian Angel of the House figure (Mrs. Ramsay). The moment when these two perspectives fuse develops into a feminist, intersubjective sublime moment in Woolf's To the Lighthouse. 
Intersubjectivity is not a particularly new concept in scholarly discussions surrounding Virginia Woolf's work. Considering that intersubjectivity developed in part as a response to work in Feminist and Gender Theory, it is not surprising that Woolf's work, which is invested in exploring subjectivity through gender, is of particular interest to scholars exploring the concept. With its consideration of the complicated relationship between subjects and objects related through aesthetics, To the Lighthouse uses everyday objects, Lily Briscoe's painting, and free indirect discourse in order to explore how subjects relate to one another. In particular, To the Lighthouse focuses on the family as the most important social unit in order to explore not only the self but others. Jessica Berman considers the importance of both ethics and aesthetics in Woolf's work through the concept of the "fold." For Berman, ethics inhabits "the fold between beings that brings them into relation, though not necessarily into a realm of familiarity, normativity, or consensus" (151). Berman points to the importance of the development of an "ethics of care" in Feminist Theory as a way of exploring the relationships between women. In making her argument, Berman focuses on many literal folds: Mrs. Ramsay's folded glove or the folded cloth surrounding Orlando. In a more scientific approach to To the Lighthouse, Vera Tobin applies the concept of "joint attention" or "the ability to share attention to some object with another person and mutually recognize that the attention is shared" (185) as a way of exploring intersubjectivity. Tobin suggests that Woolf uses joint attention to objects in order to expose shared moments. What both Berman and Tobin have in common is an approach to intersubjectivity that still relies on literal objects in order to explore subject/subject interactions.

\section{Rethinking the Sublime and Intersubjectivity}

Like intersubjectivity, the sublime is a concept that has often been applied to Woolf's work. Recent critical work explores sublimity in Woolf's oeuvre in multiple ways-from the 
comic to the postmodern. ${ }^{5}$ Combining work on the postmodern sublime and Donna Haraway's "cyborg-based feminism," Tonya Krouse analyzes the sublime moment in To the Lighthouse as a purely masculine subject/object experience revealed through the figure of Mr. Ramsay (296). Krouse writes, "[T]hrough the figure of Mrs. Ramsay, Woolf presents and attempts to access the masculinist tradition through a modernist aesthetic mode; Mrs. Ramsay, a collaborator in the patriarchal oppression of her sex, also collaborates in the traditional aesthetic of the sublime" (296). Drawing on Mrs. Ramsay as simply an object that aligns her with beauty in the beauty/sublime binary, Krouse argues, "Whereas Mr. Ramsay, by the sole virtue of his sex, represents the possibility of attaining the sublime, Mrs. Ramsay actively takes on the role of 'other' in order to secure herself a position within a patriarchal aesthetic and social framework" (296). ${ }^{6}$ As Krouse shows, when considering men and women, the traditional subject (man)/object (woman) binary holds and intersubjectivity is impossible. In reviewing the use of androgyny in Woolf, Lisa Rado suggests that Woolf was invested in representing a sublime experience for the creator through the use of the imagination. Rado argues, "Threatened most immediately by explosive revelations of patriarchal repression and its inhibiting effect upon herself as a woman writer, Woolf responds by forging a sublime union between herself and her vision of an androgyne imagination in order to generate authority and inspiration" (139-140). Here, Rado suggests that Woolf seeks sublimity for the author figure, and when applied to To the Lighthouse, Lily Briscoe represents a sublime union with Mrs. Ramsay that creates inspiration. Unlike Krouse, Rado sees Woolf rewriting the sublime as a female experience, and it is within this tradition that I develop my analysis of the sublime in the novel. For Woolf, the sublime is located between women and so defies the Kantian masculine tradition that Krouse explores in 
her criticism; however, Woolf's novel also shows that Freudian psychoanalysis informs modernist aesthetics.

Christina Froula brilliantly reconceives of the relationship between Sigmund Freud and Immanuel Kant in Bloomsbury Modernism; she suggests that Kant and Freud reflect a merging of similar ideological structures that result in a unique understanding of the modernist subject that is exposed in modernist form. In addition, Froula sees Freud as part of an Enlightenment tradition that stems especially from Kant and discussions of the modern subject. She argues that modernism, including Freud, is part of "modernity's permanent revolution" that reflects a "perpetual effort to reclaim the purpose and vitality of the Enlightenment project—as an unfinished and unfinishable struggle for human (including economic) rights, democratic selfgovernance, world community, and peace" (xii). As Froula writes, the link between Freud and Kant shows a "legacy for a world still struggling with the economic, political, social, and ethical challenges that confront women and men, races, religions, and cultures, classes and nations, as they seek to negotiate differences not by violence but through the power of speech, the effort and 'the art of understanding other people's lives and minds"' (xiii-xiv). For the avant-garde modernists like Woolf, this legacy results in an investment in a future that refutes Walter Pater's dictum "art for art's sake" (Froula xiii) or the translation of "energies of the "hopeful and exciting' prewar European political and social movement into the postwar battle for Europe's future" (Froula 2-3). Froula sees the Bloomsbury modernists as not “'saving' civilization but...fighting for its possibility" (9), which is the same goal as that of Kant in the eighteenth century.

Froula analyzes Freud's Civilization and Its Discontents in terms of its influence on the Bloomsbury's modernist perception of "civilization" and how this move produces reactionary 
aesthetic practices. In particular, Froula remarks that Freud's critique of class intertwines with his commentary on religion, linking both as a "powerful means of controlling aggression" (8). Froula writes, "Freud distinguished privations that affect everyone from those affecting 'only groups, classes or even single individuals,"” and she later continues, "If European civilization is to survive, he concludes, it must relegate religion's 'practical fictions' to its childhood and turn instead to science, which subjects its representations of reality to empirical verification, and art, which makes no truth claims and, in its symbolic gratification of instincts, reconciles people to the sacrifices civilization demands as nothing else can" (8). Ultimately, Froula sees Bloomsbury modernists as extending Freud's idea that once civilization's fragility is exposed that it could be rebuilt despite the exposure of its weakness (9). Drawing on Freud's estimation that men aggress as a result of social and political exploitation, Froula shows the Woolfs and Maynard Keynes (as well as other Bloomsbury members) as part of a group that sought the reasonable rebuilding of civilization to correct economic, political, and social questions through literature. Like Kant, these modernists seem to suggest that "reason" and objectivity are needed in order to address the wrongs of civilization.

The key aesthetic approach of Kant that extends into modernist aesthetics is the concept of "disinterestedness" or the objective perspective that requires a subject/object rather than subject/subject dynamic in order to function. Woolf's interest in the emotional and her embrace of "sentimental" writing despite critical negativity reflects even her own internalization of the need for distance as a writer while trying to display human connection on an intersubjective level. $^{7}$ In fact, her use of shifting stream-of-consciousness seeks out the emotional, the affective or what was derided as "sentimental" by early twentieth century critics always negating the possibility of disinterestedness by seeking to represent multiple perspectives. For Kant, an 
aesthetic judgment is disinterested but it always relies upon finding commonality or the "sensus communis," as he terms it (77). Froula explicitly points to this problem:

One's aesthetic judgment...is binding not on other people but on oneself, in that it requires one to put aside personal interest—sentiment - in making it. By the same token, in putting personal interest aside, one seeks common ground with others, whether or not experience confirms it. In offering disinterested aesthetic pleasure-free from personal interest, use, or purpose; relatively free, too, of particular local, national, and cultural contexts - art indirectly mediates the sociability that Kant considers humanity's 'highest end,' in line with the Enlightenment sociopolitical ideal. (12-13)

Froula points to intersubjectivity as the necessary foundation for Kant's ideal of aesthetic judgment, regardless of his insistence on individualism and the single subject. When examining the novel genre, which is most concerned with the development of character, it is not surprising that sublimity is expressed through the interconnection of characters. Like art, in everyday social interactions, a "sensus communis" in terms of emotional connection is needed in order to understand and evaluate human relationships.

Woolf's free indirect discourse exposes not only individual conscious thoughts but also the communal nature of understanding and perceiving different identities. The construction of Mrs. and Mr. Ramsay as a Victorian Angel and Patriarch via the shifting perspectives of those characters which surround them exposes not only how ideological structures create idealized gendered images but also the possibility of undermining this irony between individual and communal through rewriting Kant's aesthetic theory. For Woolf, like the male writers, sublimity is possible between two people; however, Victorian parents must function exclusively as objects in order to make that experience possible. In Woolf, the sublime moment is never reciprocal, 
because she rarely gives the reader access to the thoughts of Mr. and Mrs. Ramsay; the objects do not matter as much as they inform the realization of an ideal community.

Georgia Johnston, Carolyn Dever, and Ellen Bayuk Rosenman argue that Woolf examines Freudian concepts like the Oedipus Complex or transference in both her autobiographical work and her fiction in To the Lighthouse. ${ }^{8}$ Along with this analysis of the novel is a biographical approach that considers Woolf's writing of this novel as a way of Woolf working through her "ambivalence" about her father and the Oedipal complications of her relationship with both him and her mother. These readings tend to conflate Woolf's personal experiences with her creative choices. Although Woolf may have originally been skeptical of him, Freud becomes an influential figure in Woolf's thinking on her own psychic development, suggesting that she is more invested in subject/object dynamics than her earlier attitude makes apparent.

By the time she writes To the Lighthouse, Woolf is in the process of editing Freud's Collected Papers for the Hogarth Press, and she clearly shows a cynical attitude about some of his theories. ${ }^{9}$ Woolf's familiarity with Freud early in her career is again reflected in the conversations recorded among members of the Bloomsbury group. ${ }^{10}$ In an early diary entry, Woolf exposes her early skepticism toward psychoanalysis, which may, as Louise DeSalvo has said, have been influenced by her own mental illness and exposure to psychiatric doctors. In her diary entry for "Monday 21 January 1918," Woolf remarks upon Lytton Strachey's report at a Bloomsbury meeting on his recent visit to the British Sex Society meeting. Woolf writes,

The sound would suggest a third variety of human being, \& it seems that the audience had that appearance. Notwithstanding, they were surprisingly frank; \& 50 people of both sexes \& various ages discussed without shame such questions as the deformity of Dean 
Swift's penis: whether cats use the w.c.; self abuse; incest—Incest between parent \& child when they are both unconscious of it, was their main theme, derived from Freud. I think of becoming a member. It's unfortunate that civilisation always lights up the dwarfs, cripples, \& sexless people first. (Diary Vol. 1 110)

Although a seemingly objective list of conversation, the tone of this diary entry suggests Woolf's skeptical attitude toward Freud's writings and ideas. In particular, his focus on those "outsiders" like "dwarfs, cripples, \& sexless people" suggests a disapproval of his methods as pathologizing. Like the feminist scholars that follow her, Woolf already points to the idea that Freud's articulation of sexuality inadvertently supports heteronormative ideology as it was the historical norm for the early twentieth century. ${ }^{11}$

Later in her career, especially as World War II and her eventual suicide approaches, Woolf returns to Freud's writing. It is during this time period that Woolf begins working on her memoirs, which she never completes. In "A Sketch of the Past," the fragment of her memoir that was eventually published, Woolf evaluates the development of her own identity in terms of her family dynamics. Time has provided the necessary emotional distance from her childhood that allows Woolf to reconsider her relationship to her parents as well as her own sexual abuse at the hands of her brother. To understand her attitudes toward both her mother and her father, Woolf draws heavily on Freud's psychoanalytic concepts. After giving a detailed description of her father, Woolf inserts an odd phrase into her memoir, playing the role of psychoanalyst in order to understand her relationship to her father. Woolf writes, "But in me...rage alternated with love. It was only the other day when I read Freud for the first time, that I discovered that this violently disturbing conflict of love and hate is a common feeling; and is called ambivalence" ("A Sketch" 108). In this passage, Woolf references reading Freud for the first time, which led her to 
understand her feelings toward her father. In her diary entry from "Saturday 2 December 1939," Woolf outlines her reasons for turning to Freud in the first place: "Began reading Freud last night; to enlarge the circumference. to give my brain a wider scope: to make it objective; to get outside. Thus defeat the shrinkage of age" (Diary Vol. 5 248, my emphasis). Woolf links Freud to an objective framework, providing the tools for the production of art. Although she describes aging as "shrinking," it is time that provides Woolf with her wider scope, objectivity, and a mind in need of aesthetic distance. In the next diary entry, Woolf again brings up Freud's concept of ambivalence in relation to her own feeling and attitudes (Diary Vol. 5 249). Woolf sees herself as exhibiting "ambivalence," and ironically, it is to the theorizer of ambivalence that she turns in order to regain her objectivity, to find the subject/object interaction necessary for the appreciation and production of art.

Woolf may challenge Freud during her participation in Bloomsbury, but as she grows older, whether due to disillusion in the aftermath of World War I or her own personal struggles, she grows more skeptical about a person's ability to know or understand others. As a result, by the time she writes To the Lighthouse, Woolf relies on subject/object binaries in her examination of the relationship between parents and children. By 1939, she turns to Freud as a way of understanding her own subjectivity in relation to her art. ${ }^{12}$ For Woolf, Freud and aesthetics are intimately connected. On a simplistic level, the foundation of Freud's work is an attempt to understand those who are different; however, his assumption of a cultural or sexual normativity also alienates the "outsider." Considering the importance of being the "outsider" in the production of modernist art, Woolf sees Freud's work as undermining the creative faculty, especially of women. In To the Lighthouse, Woolf's aesthetics in the novel, especially her use of free indirect discourse, reveal the influence of Freud on Woolf's thinking about familial 
relationships. As Hermione Lee notes, Woolf writes To the Lighthouse as a way to come to terms with her own feelings about her family — focusing on her mother and father in particular. ${ }^{13}$

\section{"There it was-her picture": The Aesthetics of the Patriarchal Family}

Foundational to Woolf's feminism is the figure of the mother. In the oft-cited quote from A Room of One's Own, Woolf writes, "For we think back through our mothers if we are women" (75). Woolf emphasizes the importance of connections between women, especially between mothers and daughters in order to realize a feminist polemic. ${ }^{14}$ In what is noted as her aggressive stance against the Victorian mother, Woolf writes with a nod to Coventry Patmore's poem about ideal domesticity: "I discovered that if I were going to review books I should need to do battle with a certain phantom. And the phantom was a woman, and when I came to know her better I called her after the heroine of a famous poem, The Angel in the House. It was she who used to come between me and my paper when I was writing reviews. It was she who bothered me and wasted my time and so tormented me that I killed her" ("Professions for Women" 58). Directly following this line, Woolf defines the Angel in the House: "She was intensely sympathetic. She was immensely charming. She was utterly unselfish. She excelled in the difficult arts of family life. She sacrificed herself daily" ("Professions for Women" 59). In essence, all of these characteristics describe Mrs. Ramsay. Contrasting the mothers from A Room of One's Own with the mother in "Professions for Women," Woolf reveals a generational tension between mothers and daughters that is based on the social construction of women as an ideal object, the Angel in the House. The mothers in A Room of One's Own are the "real" mothers whose lived experiences contrast with the ideal mother revealed in "Professions for Women." When she declares that she must kill the Angel in the House, Woolf suggests that she must kill the social 
object and not the actual mother. ${ }^{15}$ In To the Lighthouse, the tension between the mother as person and mother as ideal plays out in Lily's sublime revelations about Mrs. Ramsay.

Despite Mrs. Ramsay's strict adherence to her expected gender role, Woolf implies that the intuitive and emotional components of Mrs. Ramsay's character are the grounds for an intersubjective sublime experience. The people surrounding Mrs. Ramsay come to appreciate the emotional components of her character despite her original position as a "beautiful object." Woolf's representation of Mr. Ramsay is more consistent throughout the novel, especially as the anger of his children develops more aggressively toward the end. He constantly inhabits the role of patriarchal father, never diverging from the ideological figure expected from the Victorian imaginary. Woolf's representation of Victorian parenthood informs the work of Stephen Ellis, Helen Bayuk Rosenman, and Hermione Lee; however, I move away from this line of criticism by thinking of the intersubjective possibilities revealed through sublimity. ${ }^{16}$ In particular, Lily Briscoe's positioning throughout the third section of the novel, "The Lighthouse," provides the eventual possibility of intersubjectivity through the act of painting in reflection. Lily's sublime moment is only made possible as she attempts to understand and identify not only the figure of the Victorian mother but the father as well. Both Mr. and Mrs. Ramsay become central to Lily's eventual ability to engage in the final act of creation that allows her to complete her vision through her painting.

As Roberta Rubenstein has noted, Mrs. Ramsay is indeed the character around which the novel, To the Lighthouse, revolves. She is the figure that holds her family together as well as the guests who visit the Ramsay summer home, including the antisocial Charles Tansley. Whether they love her or resent her, every character spends a significant amount of time contemplating her social role as well as her personal role in her family. Like E.M. Foster's depiction of Mrs. 
Wilcox, the majority of the reader's perspective about Mrs. Ramsay is created through how others perceive her. Woolf's free indirect discourse gives the reader access to the social perspective of Mrs. Ramsay. Surprisingly, regardless of whether the character's point-of-view is one of the actual family or of an outsider, the interpretations of Mrs. Ramsay almost always describe her in the same terms, commenting on her beauty, her domesticity, and her charity. Readers feel that they know Mrs. Ramsay as a result of these shifting perspectives, but in actuality, they are given little access to Mrs. Ramsay's own thoughts and emotions. Many critical readings of Mrs. Ramsay rely on these perspectives and actually reinforce the Freudian and Victorian construction of the mother despite attempts to complicate her role in the novel. ${ }^{17}$ These critical approaches reiterate the idea of the mother as beautiful object without considering how motherhood alters or develops a woman's subjectivity. ${ }^{18}$

The continual evaluation of Mrs. Ramsay as a beautiful object by almost every character in the novel underlines the connection between perceptions of subjectivity and aesthetic discourse. These characters see Mrs. Ramsay as the idealized Victorian mother, but at the same time, Woolf brings the concept of beauty into the equation. Woolf draws on an aesthetic tradition that objectifies the beautiful and identifies the beautiful as feminine rather than masculine. William Bankes remarks,

There was something incongruous to be worked into the harmony of her [Mrs. Ramsay's] face... So that if it was her beauty merely that one thought of, one must remember the quivering thing, the living thing... and work it into the picture; or if one thought of her simply as a woman, one must endow her with some freak of idiosyncrasy — she did not like admiration - or suppose some latent desire to doff her royalty of form as if her 
beauty bored her and all that men say of beauty, and she wanted only to be like other people, insignificant. (To the Lighthouse 33)

William Bankes shows how Mrs. Ramsay is viewed by someone outside of the family, but he sees her merely as a beautiful object. Although it would be easy to see him as trying to identify with Mrs. Ramsay, in fact, Bankes actually only conceives of her subjectivity as it aligns with expected Victorian gender roles. She is shy, humble, modest, and beautiful. The passage shifts from an aesthetic perspective (Mrs. Ramsay's beauty and the structure of her face) to one on subjectivity (Mrs. Ramsay as a woman); however, when asked to think of Mrs. Ramsay as a woman, Bankes “endows" her character rather than reading it. Bankes creates a fiction about her character without trying to identify with her perspective. Like Bankes, most of the characters create their own fictions regarding Mrs. Ramsay-informally engaging in the production of fiction or art.

The link between the beautiful mother and the aesthetic appears in the first section of the novel when Lily attempts to paint Mrs. Ramsay reading to her son, James. Again, William Bankes links Mrs. Ramsay with beauty, but his perspective intersperses with Lily’s “objective," artistic perspective of the scene. The painting of Mrs. Ramsay and her son is framed by a window, offering the title of the first section of the novel, "The Window." The framing provided by the window creates the boundaries necessary for the production of art. As Lily puts away her paintbrushes, after Mr. Ramsay's overbearing presence trespasses on her artistic production, William Bankes observes the objects which Lily tries to paint: a Madonna and child, Mrs. Ramsay and James. Bankes is enraptured, showing a love "that never attempted to clutch its object; but, like the love which mathematicians bear their symbols, or poets their phrases, was meant to be spread over the world and become part of the human gain" (To the Lighthouse 50- 
51). Here, Lily sees Bankes's act of viewing Mrs. Ramsay as a symbolic process, equivalent to language and mathematics. It maintains an objective distance as the failure to "clutch its object" actually shows an inability to consider another's subjectivity, to bring the object close, to clutch it.

This distance, like the Burkean and Kantian sublime, provides pleasure for Bankes, but no pain. As a result, his experience is that of the traditional male gaze on a beautiful object that only produces pleasure; however, Woolf writes this moment as sublime despite the failure of "pain" to be introduced into the experience. Ironically, Lily sees Bankes's "rapture" and decides not to speak, because it would break this sublime moment: "It [her comment] paled beside this 'rapture,' this silent stare, for which she felt intense gratitude; for nothing so solaced her, eased her of the perplexity of life, and miraculously raised its burdens, as this sublime power, this heavenly gift, and one would no more disturb it, while it lasted, than break up the shaft of sunlight, lying level across the floor" (To the Lighthouse 51). Lily watches as Bankes inhabits the role of the male gazer and Mrs. Ramsay as the beautiful object of the male gaze. Still, she reads this as a sublime power, a transcendent or heavenly experience. In this scene, though, the reader does not know that this is in fact a sublime moment; it is Lily's interpretation of Bankes that connects the gaze to sublimity. The slipperiness of the term "sublime" here calls into question whether Lily has access to the traditional sublime, because she can never inhabit the position of the male gazer on the beautiful. This ambivalence is further emphasized as Lily thinks, "She took shelter from the reverence which covered all women; she felt herself praised. Let him gaze; she would steal a look at her picture" (To the Lighthouse 51). Although she is not the object of Bankes's gaze, Lily feels herself inhabiting the same position as all women, but the fact that she is always outside, never the object of the gaze but the gazer causes a problem for 
Lily in the creation of art. As she looks at her painting, Lily thinks, "She could have wept. It was bad, it was bad, it was infinitely bad! She could have done it differently of course; the colour could have been thinned and faded; the shapes etherealised... But she did not see it like that. She saw the colour burning on a framework of steel; the light of a butterfly's wing lying upon the arches of a cathedral" (To the Lighthouse 51). Lily's trouble revolves around her painting's failure to conform to the realistic art forms of her male predecessors; she is less concerned with form and composition than with feeling. She wants to paint the subjective spirit not the realistic object. ${ }^{19}$

The merger of subjectivity and objectivity in Lily's artistic production, especially regarding the representation of Mrs. Ramsay, become a question of the potential for intersubjectivity. For Lily, this merger reveals a question of differentiating Mrs. Ramsay, the person, from Mrs. Ramsay, the Victorian Angel and mother. At first, Lily wants to comment to Bankes on "something critical" about Mrs. Ramsay as the consummate matchmaker (To the Lighthouse 52). Lily moves away from this critical attitude as she gazes on Bankes gazing on Mrs. Ramsay:

Looking along his beam she added to it her different ray, thinking that she was unquestionably the loveliest of people (bowed over her book); the best perhaps; but also, different too from the perfect shape which one saw there. But why different, and how different?...How did she differ? What was the spirit in her, the essential thing, by which, had you found a crumpled glove in the corner of a sofa, you would have known it, from its twisted finger, hers indisputably? (To the Lighthouse 52) 
Lily questions Mrs. Ramsay's symbolic position as the beautiful, domestic, motherly object. As she watches Bankes gaze on Mrs. Ramsay, Lily brings the issue of subjectivity into the question of form or shape.

Mrs. Ramsay is a shape, a symbolic marker, but Lily also notes that she, as a person, must be different than the ideological object. Lily desires an intersubjective communion between herself and Mrs. Ramsay:

Was it wisdom? Was it knowledge? Was it, once more, the deceptiveness of beauty, so that all one's perceptions, half-way to truth, were tangled in a golden mesh? or did she lock up within her some secret which certainly Lily Briscoe believed people must have for the world to go on at all?...What art was there, known to love or cunning, by which one pressed through into those secret chambers? What device for becoming, like waters poured into one jar, inextricably the same, one with the object one adored? Could the body achieve, or the mind, subtly mingling in the intricate passages of the brain? of the heart?...for it was not knowledge but unity that she desired, not inscription on tablets, nothing that could be written in any language known to men, but intimacy itself, which is knowledge. (To the Lighthouse 53-54, my emphasis)

What Lily constantly questions in her relationship to Mrs. Ramsay is not a position that can be understood as a mother/daughter relationship but more broadly as an intersubjective relationship. Lily may desire to know the mother's subjectivity, but she also wants to know Mrs. Ramsay apart from the ideological roles she is expected to fulfill. As Lily correctly notes, this merger can never be articulated through language, because language, like art, always relies on the worship of an object. 
Unlike the men in the text, Mrs. Ramsay and Lily Briscoe gain access to intersubjective sublime experience through their knowledge that language always fails, a trope of the traditional sublime. Not only for the artist, but for the woman as well, language can never convey the sublime experience, because intersubjectivity is actually the key foundation of sublimity when related to language or art. As noted earlier, Christine Froula points to the fact that Kantian aesthetic judgment relies on a communal understanding. Woolf expands upon this communal understanding by implying that in the production of art, intersubjectivity is needed between the artist and her object as well as the artist and her audience. Burke and Kant link the failure of words to sublimity, because words cannot convey a true intersubjective experience between writer and reader. For Woolf, intersubjectivity is only possible between characters who realize the constant failure of language to convey subjectivity, whether through writing or through communication. Sublimity only occurs for those characters that denounce language and engage in an emotional/affective experience.

Woolf explicitly links Mrs. Ramsay and motherhood with the failure of language, a trope of the sublime. Woolf first associates the importance of non-language with Mrs. Ramsay as Mr. Ramsay tries to draw sympathetic language from her. Worrying about his own failures, Mr. Ramsay sees Mrs. Ramsay as a shelter meant to protect the patriarch. His attitude suggests that although the patriarch is typically associated with power, the central power of the family rests in Mrs. Ramsay. Mrs. Ramsay's responses to Mr. Ramsay’s overuse of language and concern with playing the role of failed genius suggests that he consider the emotional. She advises that "He must have sympathy. He must be assured that he too lived in the heart of life" or "Well, look then, feel then" (To the Lighthouse 41). The passage shifts from Mr. Ramsay's to Mrs. Ramsay's perspective when the voice of an omniscient narrator intervenes. In each case, what 
the reader understands as the character of the other is actually conveyed through another's perspective - not the perspective of the actual mother or father. The narrator comments on Mr. Ramsay's need for shelter: "So boasting of her capacity to surround and protect, there was scarcely a shell of herself left for her to know herself by; all was so lavished and spent" (To the Lighthouse 41). As the novel continues, Mrs. Ramsay reveals her failure to know herself and has a specific attitude toward language and gender. In a rare moment from her point-of-view, Mrs. Ramsay connects emotion and wordlessness to her mother: "What was the reason, Mrs. Ramsay wondered...divining, through her own past, some deep, some buried, some quite speechless feeling that one had for one's mother at Rose's age" (To the Lighthouse 83-84). For Mrs. Ramsay, language, which she connects with male figures like her husband and Charles Tansley, fails to convey the emotions between women's relationships. Even in her relationship to her own daughter, Mrs. Ramsay seeks an intersubjective ground, trying to find from her own past an understanding of how her daughter feels about her, the mother.

When she draws on her own experiences and emotions, Mrs. Ramsay can no longer maintain the position of beautiful object and instead inhabits a subject position. By shifting the perspective from the outside (via others' perspectives) to the inside, Woolf makes sublimity possible for Mrs. Ramsay despite its identification with masculine subjectivity. Mrs. Ramsay's sublime moment stems from a moment of wordless communication, surrounding the issue of love for her husband. After a long day and an elaborate dinner, Mrs. Ramsay retreats to an empty space, alone from her company. At this point, Mrs. Ramsay is tired of making conversation, so she expects her husband to fill the silences, to say something; however, this moment alone with his wife is one of the few where Mr. Ramsay shows some restraint, refusing to overburden his wife. It is Mrs. Ramsay who wants him to speak, hoping that his language and 
its power will protect them: "What was the value, the meaning of things? (Every word they said now would be true.) Do say something, she thought, wishing only to hear his voice. For the shadow, the thing folding them in was beginning, she felt, to close round her again. Say anything, she begged, looking at him, as if for help" (To the Lighthouse 124). In this brief passage, Mrs. Ramsay keeps referring to the "thing" which she feels approaching. The use of the word "thing" here foreshadows Woolf later description of Mrs. Ramsay as the "thing itself," which Roberta Rubenstein has noted is the central focus of the novel. Woolf consistently uses the word "thing" to address that which escapes language and appears through emotion.

In this brief glimpse of the relationship between Mr. and Mrs. Ramsay, the issue of communication is central to who gains access to a sublime intersubjective experience. The scene shows that Mrs. Ramsay identifies with the "failure of language" and that failure represents her sublime moment through her attempt to identify with and understand Mr. Ramsay. Mrs. Ramsay thinks,

He wanted something — wanted the thing she always found it so difficult to give him; wanted her to tell him that she loved him. And that, no, she could not do. He found talking so much easier than she did. He could say things—she never could. So naturally it was always he that said the things, and then for some reason he would mind this suddenly and would reproach her. A heartless woman he called her; she never told him that she loved him. But it was not so-it was not so. It was only that she never could say what she felt. (To the Lighthouse 125)

In this passage, Woolf suggests that the split between Mr. and Mrs. Ramsay exists in their relationships to language. Mr. Ramsay wants the words; whereas, Mrs. Ramsay wants the silent emotion. 
The refusal to speak leads to a reversal of the typical subject/object power dynamic; Mrs. Ramsay refuses to inhabit the position of the beautiful object. Instead, she reverses the subject/object dynamic, making Mr. Ramsay the "sublime object" that gives her a sense of triumph over her fears of Mr. Ramsay's expectations. Unfortunately, Mrs. Ramsay's sublime experience maintains the subject/object power dynamics expected from the sublime; however, she does reverse the gendered binary that associates sublimity with masculinity. Mrs. Ramsay thinks,

She knew what he was thinking. You are more beautiful than ever. And she felt herself very beautiful. Will you not tell me just for once that you love me? He was thinking that, for he was roused... But she could not do it; she could not say it. Then, knowing that he was watching her, instead of saying anything she turned, holding her stocking, and looked at him. And as she looked at him she began to smile, for though she had not said a word, he knew, of course he knew, that she loved him. He could not deny it. (To the Lighthouse 125-126)

Like the previous passage, the narrative voice is hard to follow and leads the reader into thinking that this is how Mr. Ramsay feels about Mrs. Ramsay. If, though, one pays close attention to whose perspective this passage conveys, Mrs. Ramsay confirms her own desires by saying that Mr. Ramsay knew her feelings without words. But, as the earlier passage showed, Mr. Ramsay wants her to use words to communicate love. Mrs. Ramsay places her own desires on Mr. Ramsay, giving her the sense of individual sublimity resulting from the traditional wordless sublime moment: "And she looked at him smiling. For she had triumphed again. She had not said it: yet he knew" (To the Lighthouse 126). In this brief passage, Mrs. Ramsay engages in a similar tyranny to that of Mr. Ramsay. Due to the shifting narrative voice from Mrs. Ramsay's 
perspective, it is not clear to the reader that Mr. Ramsay actually knows. Like Mr. Ramsay, Mrs. Ramsay thrusts her perspective on others rather than seeking an intersubjective groundwork. Woolf's use of Mr. Ramsay as a "sublime object" actually showcases that his subjectivity is as bounded as that of Mrs. Ramsay. The sublime moments between two characters actually exhibits the performance of gendered identities for both men and women. Mrs. Ramsay refuses to speak, enforcing the failure of language as its inability to show lived experience or emotion in any adequate manner. Mr. Ramsay refuses emotion and experience in preference to the mask of language.

Mrs. Ramsay presents an intersubjective sublime moment through the failure of language, but it is Mr. Ramsay that epitomizes the actual failure of language in the text. Like the Angel whose identity is predicated on her beauty and position as mother, Woolf shows that Mr. Ramsay's position as patriarch is predicated on language and discourse. The perceived identity of the patriarch, like that of the Angel, is constructed through gendered ideological discourses. In the case of Mr. Ramsay, that discourse includes the Romantic and Victorian idea of "genius."20 Mr. Ramsay's identification with language is further stressed by his position as a writer and a critic. Like Mrs. Ramsay’s association with beauty, Mr. Ramsay's association with language is almost always conveyed through the thoughts of other characters. When he first paces the garden quoting Alfred, Lord Tennyson, Mrs. Ramsay is worried that others will view his pacing but is relieved to find only Lily Briscoe is around for "that did not matter" (To the Lighthouse 20). Throughout "The Window," multiple characters, like Mrs. Ramsay, comment on Mr. Ramsay's pacing and his quotation of literature: some characters dismissing it as the disposition of "genius" while others view this as the language of a tyrant. From almost his first 
introduction, Mr. Ramsay is constantly viewed by others as wielding language and using it to reinforce his tyrannical behavior.

The reader only gains access to Mr. Ramsay's relationship to language through the comments of an omniscient narrator. The narrator comments on Mr. Ramsay's fixation with working through the letters of the alphabet, which functions as a systematic metaphor of the progress of Mr. Ramsay's mind and genius. Mr. Ramsay has “reached Q. Very few people in the whole of England ever reach Q" (To the Lighthouse 37). The problem for Mr. Ramsay lies in what exists after Q: " $\mathrm{Z}$ is only reached once by one man in a generation. Still, if he could reach $\mathrm{R}$ it would be something. Here at least was Q. He dug his heels in at Q. Q he was sure of. Q he could demonstrate. If Q then is—R...'Then R...' He braced himself. He clenched himself' (To the Lighthouse 37). He then goes on to ask, "What is R?" (To the Lighthouse 37). Woolf's choice of the letter " $R$ " is important because it connects to his surname, Ramsay. According to the narrator, "R" represents that which has yet to be assigned meaning for Mr. Ramsay. If we view this letter as a representation of his name, Woolf shows a disconnect between the process of naming and meaning. Although it seems that Mrs. Ramsay is the only character who taps into the failure of language, Mr. Ramsay is also aware of how language fails and the process of symbolization related to the creation of meaning. Like the description of Mrs. Ramsay's realization of the failure of language, the reader is not given access to Mr. Ramsay's perspective on how language functions to him and what it represents. In both cases, the Victorian parent maintains distance from the reader through the free indirect discourse that shifts from character to character and omniscient narrator. The parents remain distanced not only from the reader but from the family unit represented in the novel. 
The narrator notes that the alphabet also has a secondary meaning for Mr. Ramsay related to mortality; his failure to complete the alphabet represents his coming death. " $\mathrm{R}$ " then comes to represent for Mr. Ramsay the unknown as well as his failure to comprehend or reach that unknown. If we read the " $\mathrm{R}$ " as a signal to the surname "Ramsay," what Mr. Ramsay fails to reach is an understanding of his self. Of "R," the narrator connects the alphabet to a mountain scene, a common trope of the British Romantic sublime:

Feelings that would not have disgraced a leader who, now that the snow has begun to fall and the mountain top is covered in mist, knows that he must lay himself down and die before morning comes, stole upon him, paling the colour of his eyes, giving him, even in the two minutes of his turn on the terrace, the bleached look of withered old age. Yet he would not die lying down; he would find some crag of rock, and there, his eyes fixed on the storm, trying to the end to pierce the darkness, he would die standing. He would never reach R. (To the Lighthouse 38)

The language used in this passage to connect Mr. Ramsay to the problems of language pull from multiple tropes of the sublime: the mountain, a storm, darkness, and the infinite. For Mr. Ramsay, death is a by-product of language, specifically the language of the eighteenth century. Unlike Mrs. Ramsay, Mr. Ramsay never fulfills the Burkean or Kantian sublime dynamic that requires the establishment of ego, confirming the self. Mr. Ramsay understands the language associated by the sublime, but throughout the novel, he functions as a sublime "object" in the same way that Mrs. Ramsay represents the beautiful "object." It is not until the end of the novel when Mr. Ramsay travels back to the lighthouse (a symbolic object representing the mother) that Mr. Ramsay functions as a sublime subject for Lily. 
During this journey to the lighthouse, Woolf explicitly connects Mr. Ramsay to eighteenth century language and the sublime through his quotation of William Cowper's "The Castaway." This poem about a castaway at sea after a storm again invokes the eighteenth century British Romantic tradition of the sublime in the same way that Mr. Ramsay connects the mountain to the alphabet. Constantly repeating "and we perished each alone," Mr. Ramsay implies that each person is a castaway on his journey to the lighthouse. Unlike D.H. Lawrence, who sees the possibility for connection, Woolf returns to the feeling of being alone and apart. Each character is alone, including Lily, despite her later sublime experience. As Mr. Ramsay quotes the lines, the other characters pick up the act of quoting the line, including Cam and Lily Briscoe. Mr. Ramsay again uses the language of literature, representing empty words and nonsense to express what should be an emotional experience. Woolf connects Mr. Ramsay to masculine discourse and the sublime. To the other characters in the novel, this discourse is "nonsense" that reveals Mr. Ramsay's failure as a patriarchal figure. Language marks a key gendered distinction between Mr. and Mrs. Ramsay, allowing Woolf to expose other potential ways of communicating through silence. In essence, Woolf shows a modernist interpretation of the sublime that shifts its meaning form the realm of reason to emotion.

Like Mrs. Ramsay, the question of Mr. Ramsay's subjectivity is not addressed until he travels to and reaches the lighthouse. During this trip, Mr. Ramsay's tyrannical position appears to be reaffirmed by the thoughts and actions of two of his children, James and Cam. Cam expresses conflicted feelings about her father that come into conflict with him as a purely tyrannical figure:

For no one attracted her more; his hands were beautiful, and his feet, and his voice, and his words, and his haste, and his temper, and his oddity, and his passion, and his staying 
straight out before every one, we perish, each alone, and his remoteness...But what remained intolerable, she thought... was that crass blindness and tyranny of his which had poisoned her childhood and raised bitter storms, so that even now she woke in the night trembling with rage and remembered some command of his; some insolence: "Do this,:

"Do that," his dominance: his "Submit to me." (To the Lighthouse 173)

Cam shows her feelings to be conflicted, finding the very components that make Mr. Ramsay a tyrant also make him an intriguing figure. Her feelings about him suggest that the "father" exists separately from the "patriarch," revealing that one is natural and the other is a role that must be fulfilled in order to conform to social expectations. Like the mother from whom the child must separate, the father also represents a split for the child. The "bad" mother like the "bad" father result from the rules and restrictions created through civilization and society. These are the figures that are needed in order to make the child a social being-one is the "real" parent while the other is its symbolic function.

Despite the suggestion that patriarchy represents a lineage that gives sons access to the same privileges as the father, James's response to his father is very similar to that of Cam, suggesting that the split applies to both parents and to all children regardless of their sex. In fact, James feels a strong sense of injustice rather than privilege afforded through the tyranny of his father. James thinks,

He had always kept this old symbol of taking a knife and striking his father to the heart. Only now, as he grew older, and sat staring at his father in an impotent rage, it was not him, that old man reading, whom he wanted to kill, but it was the thing that descended on him-without his knowing it perhaps: that fierce sudden black-winged harpy, with its talons and its beak all cold and hard, that struck and struck at you (he could feel the beak 
on his bare legs, where it had struck when he was a child) and them made off, and there he was again, an old man, very sad, reading his book. That he would kill, that he would strike to the heart. Whatever he did...that he would fight, that he would track down and stamp out - tyranny, despotism, he called it - making people do what they did not want to do, cutting off their right to speak. (To the Lighthouse 187)

Like his sister, James is torn between the image of his father as a man and the tyrant that he turns out to be. Woolf's image of the harpy that descends on Mr. Ramsay is confusing as a result of the shifting narrative voice.

The harpy descends on Mr. Ramsay without his potential knowledge of it, which suggests that there are larger forces to Mr. Ramsay's behavior than simply a tyrannical heart, the same heart which James wants to pierce. The line "without his knowing it perhaps" suggests that Mr. Ramsay plays the role of the tyrannical despot or patriarch. This becomes clearer as the talons which originally strike at Mr. Ramsay become a part of him and strike James. The harpy assails Mr. Ramsay, and the interaction with the creature pushes him to perform the role of patriarch rather than the grieving husband and father. The larger social implications are suggested by the use of "you," as it addresses the reader, who, like the characters, is part of the social machinery that reproduces or is victim to strict gender roles guided by parents. Woolf's parallel use of empathy and tyranny in the depiction of both Cam and James's attitude toward their father implicitly questions Freudian psychoanalysis that constantly places the issue of subjectivity on the child while the parent remains an object. The divided emotional response by James and Cam to their father suggests that a core issue for the child is understanding the parent as subject, as "mother" or "father," or object, as "Angel" or "Patriarch." Woolf begins moving towards an empathic sublime that recognizes each parent as a subject rather than an object. This move 
solidifies as the creation of art (Lily's painting) intersects with her emotional responses to both Mr. and Mrs. Ramsay.

Woolf's choice to locate Lily, the artist, outside of the family structure is crucial to the interplay between aesthetics and emotion that results in a sublime moment; however, Woolf maintains the subject/object binary associated with the traditional sublime. What is progressive about Lily's sublime experience is that it does in fact reveal the subjectivity of both Mr. and Mrs. Ramsay, but it does so without the possibility of reciprocation or growth for the parents themselves. Although she implies that Victorian parenthood is constructed through ideology and that parental subjectivity is separate from ideology, Woolf only allows the constraints of the mother, not the father, to be revealed from the mother's point-of-view. As Paula Bennett has argued, the final section of the novel, "The Lighthouse," showcases a return to the mother for the children, husband, and even Lily. Lily, though, is the only character who experiences this return from a distance, interpreting the emotional reactions of others through painting. For Woolf, sublimity still lies in the traditional realm that results in the production of art or aesthetic representation from a distance. Although the reader is privy to the events in Mr. Ramsay's trip to the lighthouse with his children, much of "The Lighthouse" section is narrated either through an omniscient narrator or the thoughts of Lily Briscoe. Family relationships are mediated from the outside, constructed through the reenactment of social norms.

Lily Briscoe conveys the family dynamics and relationships throughout most of the novel. What the reader often sees as the "real" emotions or character of figures like Mrs. and Mr. Ramsay are often mediated through the thoughts of Lily. While the novel explores multiple subjectivities through Woolf's free indirect discourse, critics have rarely looked closely at how Woolf's aesthetic style can also lead to confusing and contradictory readings of the novel. ${ }^{21}$ The 
narrative space that is given to both Mr. and Mrs. Ramsay's actual thoughts, feelings, and emotions is relatively small, but the reader feels that Mrs. Ramsay IS the Angel of the house or that Mr. Ramsay cannot be anything more than a bullying, tyrannical, patriarch. These perspectives are established most often through Lily's constant interpretations of the family as an outsider. Lily sees men like Mr. Ramsay as stifling her ability to create art (To the Lighthouse 151), especially in response to Charles Tansley's insistence that "Women can't paint" (To the Lighthouse 51). Much of Lily's examination of Mr. Ramsay is related to the production of art, and the same is true of Mrs. Ramsay. Lily feels Mrs. Ramsay's fixation on marriage also challenges her ability to create art as well, commenting on the Ramsays' marriage as a love that requires sacrifice at the altar (To the Lighthouse 103-105). Lily finds Mrs. Ramsay's role as matchmaker and Victorian mother as much a threat as Mr. Ramsay’s patriarchal control, linking the two together as coconspirators inhibiting her production of art. Lily cannot see the marriage between the Ramsays as anything but threatening, because the ideological roles they inhabit inhibit the creative production of women artists. As a result, Mrs. Ramsay is not the only figure who functions as the "object” of speculation for Lily's art.

Both Mr. and Mrs. Ramsay inhabit the position of the aesthetic "object" by the end of the novel, showing Lily's worship of objects and the creation of art. When she begins painting Mrs. Ramsay reading to her son James, Lily inserts Mrs. Ramsay into the role of Madonna and child, a traditional, ideological image of the mother. Lily represents this relationship in abstract form, causing William Bankes to question how a triangle represents the beauty of the scene between mother and son. Christine Froula argues that Lily's painting is an abstract expression of Freud's Oedipal triangle, showing that the heart of the painting is the issue of subjectivity regardless of its abstract form. During the early half of the novel, Lily is unable to finish her painting as she 
feels constantly threatened by the patriarchal family that prohibits her production of art. It is not until the end of the novel, after Mrs. Ramsay has died and Mr. Ramsay has become a pathetic character, that Lily finishes the painting, because she imagines the family as symbolically whole through the journey to the lighthouse that represents a return to the mother. ${ }^{22}$ Once the family becomes symbolically whole through the movement to the lighthouse, Lily finishes her symbolic painting through the distance the water provides. Like the gazer of a shipwreck from the distance of the shore, Lily undergoes a sublime moment that reveals her complicated relationship to the figures of the Victorian parents. For the reader, Woolf does not make this sublime moment so simple. The reader is given access to the tension between Cam, James, and Mr. Ramsay in the boat ride to the lighthouse. By giving more than Lily's aesthetic interpretation and artistic representation, Woolf showcases the problem of subjectivity. Any subject, like Lily, can only ever really know half of the story; however, through empathy, one can reach for an ethical and intersubjective response to the relationship between two people. Woolf complicates human interactions by showing the failure of representation. In essence, by giving both reality and what Lily imagines, Woolf invokes the very heart of the sublime. Through emotion and needed distance, Lily can undergo a sublime experience, and more importantly, Woolf invokes the sublime by showing the failure of language in representation. By giving both what can and cannot be known, Woolf uses a trope of the sublime to complicate traditional aesthetic modes.

Lily's sublime experience results not only in the final stroke that completes her painting, but in a recognition that the physical distance provides the emotional distance that allows her to represent Victorian parents. But, more importantly, Lily finally begins to understand how her own points-of-view reflect an internalization of social norms that sees the Victorian parent as stock figures without regard to their own subjectivity. Lily reminisces about Mrs. Ramsay's 
writing of letters on the seashore with her children while Lily tries to paint. While remembering Mrs. Ramsay's question about an object in the distance: "Is it a boat? Is it a cork?" (To the Lighthouse 174), Lily immediately questions the use of space in her painting. Lily thinks, "Heaven be praised for it, the problem of space remained, she thought, taking up her brush again. It glared at her. The whole mass of the picture was poised upon that weight...And she began to lay on a red, a grey, and she began to model her way into the hollow there. At the same time, she seemed to be sitting beside Mrs. Ramsay on the beach" (To the Lighthouse 174). Lily's ability to paint is tied to her memory of Mrs. Ramsay, which calls the issue of objective perspective and space into question.

The issue of space weighs on Lily until she begins to see the world through Mrs. Ramsay's eyes. Lily thinks,

Mrs. Ramsay sat silent. She was glad, Lily thought, to rest in silence, uncommunicative; to rest in the extreme obscurity of human relationships. Who knows what we are, what we feel? Who knows even at the moment of intimacy, This is knowledge? Aren't things spoilt then, Mrs. Ramsay may have asked (it seemed to have happened so often, this silence by her side) by saying them? Aren't we more expressive thus? The moment at least seemed extraordinarily fertile. (To the Lighthouse 175)

Lily realizes what Mrs. Ramsay's silence represents about human relationships and feelings. Once she begins to question her own harsh criticism of Mrs. Ramsay, Lily's painting comes into perspective. Like Mrs. Ramsay's sublime experience related to the failure of language, Lily's introspection leaks onto her painting through memory, which provides the emotional distance necessary to conceive of Mrs. Ramsay as a "sublime subject." After this moment of remembering, Lily returns to her painting: "Lily stepped back to get her canvas—so-into 
perspective. It was an odd road to be walking, this of painting. Out and out one went, further and further, until at last one seemed to be on a narrow plank, perfectly alone, over the sea. And as she dipped into the blue paint, she dipped too into the past there" (To the Lighthouse 175). Lily's perspective for her painting only arrives after she has dipped into the past, drawing Mrs. Ramsay's subjectivity into perspective.

Lily's reflection on Mrs. Ramsay brings perspective to her painting but it is not enough to bring her to the sublime moment. Lily must use the distance created between her and Mr. Ramsay to reach a moment of transcendence: "Distance had an extraordinary power; they [Mr. Ramsay, James, and Cam] had been swallowed up in it, she felt, they were gone for ever, they had become part of the nature of things. It was so calm; it was so quiet" (To the Lighthouse 191). Distance brings the calm necessary for reflection that allows Lily to consider Mr. Ramsay's subjectivity in a similar manner to that of Mrs. Ramsay. Lily connects distance to emotion:

So much depends then, thought Lily Briscoe, looking at the sea which had scarcely a stain on it, which was so soft that the sails and the clouds seemed set in its blue, so much depends, she thought, upon distance: whether people are near us or far from us; for her feeling for Mr. Ramsay changed as he sailed further and further across the bay. It seemed to be elongated, stretched out; he seemed to become more and more remote. He and his children seemed to be swallowed up in that blue, that distance. (To the Lighthouse 194) Lily's ability to understand Mr. Ramsay and begin to feel sympathy for him occurs as the distance between them becomes greater. The distance allows Lily to contemplate the complicated nature of human relationships whose proximity cloud one's ability to empathize 
with others. As Mr. Ramsay moves away, Lily finds that her feelings toward him change, moving toward understanding, toward what Lily terms the "thing itself" (To the Lighthouse 196). Although Roberta Rubenstein has argued that the "thing itself" is only Mrs. Ramsay, I suggest that the "thing itself" is the realization that both Mr. and Mrs. Ramsay play roles that do not represent who they are or their relationship to one another. As she moves closer to her sublime moment that results in the completion of her painting, Lily uses the emotional distance of memory to reconsider Mr. and Mrs. Ramsay's courtship and marriage. In the closing of the novel, Lily relays what she imagines happens between the Ramsays, recognizing that imagination plays a key role in the construction of empathy and the possibility of intersubjectivity. Like any child, Lily must imagine the relationship between the parents. She must fill in the gaps and fissures of the past. Lily's attempt to empathize with the figures that she so strongly resists and who she finds so constricting suggests that Woolf, like the other authors in this project, experiments with the traditional form and dynamic of the sublime.

Woolf gives this experience only to women and to Lily, the artist, rather than the parents themselves. Lily begins thinking of the relationship between Mr. and Mrs. Ramsay as a reflection of Mrs. Ramsay's weakness toward her husband through her constant attempts to please him (To the Lighthouse 198-199). Lily also thinks of the possibility that others do not like Mrs. Ramsay, especially when she plays the role of the consummate hostess, the Victorian Angel (To the Lighthouse 198-199). Lily begins to see that what others dislike is the social role and not necessarily the woman herself. Lily recognizes that one's opinions of others often reflect a person's own emotions without any objectivity or perhaps, reason (To the Lighthouse 200). This leads Lily to think, 
One wanted fifty pairs of eyes to see with, she reflected. Fifty pairs of eyes were not enough to get round that one woman with, she thought. Among them, must be one that was stone blind to her beauty. One wanted most some secret sense, fine as air, with which to steal through keyholes and surround her where she sat knitting, talking, sitting silent in the window alone; which took to itself and treasured up like the air which held the smoke of the steamer, her thoughts, her imagination, her desires. (To the Lighthouse 201)

Lily begins with Mrs. Ramsay. She desires having multiple eyes, so that she can have multiple perspectives that give her a real sense of who Mrs. Ramsay is. Woolf constantly questions one's ability to actually know someone else. This issue is clear as Lily reminisces over Mrs. Ramsay. The issue of perception and distance is directly questioned through emotional interactions.

Lily then draws Mr. Ramsay into the equation, trying to see him through Mrs. Ramsay's eyes rather than her own. Lily remembers scenes of Mrs. Ramsay knitting, interrupted by Mr. Ramsay: "She [Mrs. Ramsay] would stop knitting for a second. She would look intent. Then she would lapse again, and suddenly Mr. Ramsay stopped dead in his pacing in front of her and some curious shock passed through her and seemed to rock her in profound agitation on its breast when stopping there he stood over her and looked down at her. Lily could see him" (To the Lighthouse 201). This scene replays in Lily's memory, showing an unspoken connection between husband and wife. Lily's description ends with the brief statement: "Lily could see him." The ambiguity to this statement suggests not only that Lily can see the scene in her mind, but that she finally arrives at some sort of understanding about Mr. Ramsay. Lily finally sees him as Mrs. Ramsay sees him. 
The scene continues, shifting from this household scene to an imagined boat where Mr. Ramsay courts Mrs. Ramsay:

He stretched out his hand and raised her from her chair. It seemed somehow as if he had done it before; as if he had once bent in the same way and raised her from a boat which, lying a few inches off some island, had required that the ladies should thus be helped on shore by the gentlemen...Letting herself be helped by him, Mrs. Ramsay had thought (Lily supposed) the time has come now. Yes, she would say it now. Yes, she would marry him...Time after time the same thrill had passed between them—obviously it had, Lily thought, smoothing a way for her ants. She was not inventing; she was only trying to smooth out something she had been given years ago folded up; something she had seen. (To the Lighthouse 201-202)

Lily imagines this courtship scene that ends in marriage for the Ramsays. This scene is not necessarily the courtship scene that occurred between the Ramsays. Lily imagines that this is how their life unfolds, and as she attempts to see through others' eyes, Lily presses her own judgments on the scene, suggesting that the marriage is a mistake (To the Lighthouse 203-204). Lily believes that marriage has ruined Mrs. Ramsay, causing her death, or letting "her [Mrs. Ramsay's] flowers fall from her basket" (To the Lighthouse 204). In reality, Lily can only see part of the relationship between the Ramsays. She must use her imagination in order to contemplate what she cannot know, and in essence, it is the intervening of her imagination that suggests Lily's ability to empathize. Barbara Claire Freeman argues that in the Kantian sublime, feminine imagination must be sacrificed in order for reason to intervene, but in Woolf's feminist revision of the sublime, imagination encourages empathy which makes an intersubjective 
sublime moment possible between women. ${ }^{23}$ Woolf's sublime embraces intersubjectivity through conceits that have typically been feminized in traditional aesthetics.

This reverie is still part of the buildup to Lily's sublime experience, and the narrative shifts back to Lily's painting. As she tries to keep "looking without for a second relaxing the intensity of emotion," Lily returns to the concreteness of objects as opposed to the subjectivity of people and emotions: "One wanted, she thought, dipping her brush deliberately, to be on a level with ordinary experience, to feel simply that's a chair, that's a table, and yet at the same time, It's a miracle, it's an ecstasy" (To the Lighthouse 204). As she tries to maintain her objectivity, the transcendence of Mrs. Ramsay comes upon her:

Some wave of white went over the window pane. The air must have stirred some flounce in the room. Her heart leapt at her and seized her and tortured her.

'Mrs. Ramsay! Mrs. Ramsay!' she cried, feeling the old horror come back-to want and not to have. And then, quietly, as if she refrained, that too became part of ordinary experience, was on a level with the chair, with the table. Mrs. Ramsay - it was part of her perfect goodness — sat there quite simply, in the chair, flicked her needles to and fro, knitted her reddish-brown stocking, cast her shadow on the step. There she sat. (To the Lighthouse 204-205)

The scene Lily imagines creates Mrs. Ramsay as an integral part. The emotional becomes as concrete as an object like a chair or table. By realizing that Mrs. Ramsay functions as an object in this scene, Lily gains perspective on Mrs. Ramsay's subjectivity as Victorian mother and wife. Mrs. Ramsay integrates into ordinary experiences that result in the transcendent. Lily, though, is still not done. She must now deal with the father: "Where was that boat now? And Mr. Ramsay? She wanted him" (To the Lighthouse 205). 
Before she can finish her painting, Lily must confront Mr. Ramsay's subjectivity in the same way that she has confronted Mrs. Ramsay. She must see the difference between the man and the ideological construction. Mr. Ramsay finally reaches the lighthouse, but the narrative shifts to the voice of the omniscient narrator instead of Lily's. The narrator details Mr. Ramsay's interaction with his children and the lighthouse keeper once they finally reach this important, symbolic structure. The novel does not end with this voice as the final chapter shifts back to Lily's imaginings, especially of Mr. Ramsay and his return to Mrs. Ramsay through the symbolic lighthouse. Lily thinks, "The effort of looking at it [the lighthouse] and the effort of thinking of him landing there, which both seemed to be one and the same effort, had stretched her body and mind to the utmost. Ah, but she was relieved. Whatever she had wanted to give him, when he left her that morning, she had given him at last" (To the Lighthouse 210). Lily sees herself as struggling to imagine Mr. Ramsay's arrival at the lighthouse in much the same way that she struggled to imagine the scenes of domesticity surrounding Mrs. Ramsay. Mr. Ramsay's arrival at the lighthouse is a gift from Lily - a gift of a return to Mrs. Ramsay. Lily realizes her complicity in the creation of a particular ideological image of the Victorian parent. Her gift to Mr. Ramsay reflects the stretching of her mind that results in a moment of transcendence necessary for sublimity.

Lily reunites the Victorian parents not as Angel and Patriarch but as mother and father, woman and man. This reunion allows Lily to finally complete that moment, participating in a final act of creation and representation. Woolf writes of Lily:

Quickly, as if she were recalled by something over there, she turned to her canvas. There it was-her picture. Yes, with all greens and blues, its lines running up and across, its attempt at something...She looked at the steps; they were empty; she looked at her 
canvas; it was blurred. With a sudden intensity, as if she saw it clear for a second, she drew a line there, in the centre. It was done; it was finished. Yes, she thought, laying down her brush in extreme fatigue, I have had my vision. (To the Lighthouse 211).

Lily's vision is her sublime moment. The act of drawing the line, the centre-the symbolic lighthouse in the middle of her painting suggests the incorporation of the maternal into the act of creation. Lily, though, cannot integrate that maternity into her painting without paternity, and she cannot integrate either without both physical and emotional distance through memory. The tension between mother and father, artist and subject, and subject and object all validate the emotional as a key component of the sublime. Through empathy, sublimity is found, regardless of the fact that Lily maintains the subject/object binary of the traditional sublime.

Like William Faulkner, E.M. Forster, and D.H. Lawrence, Woolf resituates the sublime in emotion and empathy as opposed to reason and logic. She rewrites the sublime as a moment of empowerment in artistic creation through the validation of emotion. Also, like her male peers, Woolf exposes the Victorian parents as social constructs that function as "sublime objects" for modernist children and artists. Unlike these male writers, Woolf sees this emotional sublimity as situated in the position of the mother and the female artist. Considering her feminist politics, Woolf situates a feminist sublime in this particular novel. For Lily, part of that sublime experience is in her reconsideration of both the Angel and the Patriarch in her attempt to imagine the past and represent emotion in abstract art. In Lily's sublime experience, Woolf imagines a feminist sublime that seeks empathy through intersubjectivity. By connecting this sublime more strongly to the relationship between Lily and Mrs. Ramsay, Woolf realizes the possibility of intersubjectivity by contesting the Angel's complicity in patriarchal culture. Only by connecting woman to woman, can Lily go on to paint. By empathizing with the mother's complicity in 
patriarchal culture, only then can Lily imagine a feminist future. To imagine an intersubjective relationship that might exist between the sexes, Lily must first succeed in creating an intersubjective moment between different generations of women. 


\section{Epilogue}

Intersubjectivity, Feminism, and the Mother

At the end of the Sublime Object of Ideology, Žižek moves away from a literal discussion of the sublime into a larger discussion of ideology based on Hegelian philosophy. The figure that Žižek uses as his example is the mother, and like his analysis of the sublime, he avoids the mother's emotional interactions with ideology. Žižek employs the mother as an example of Hegel's concept of the "beautiful soul" or one who "structures the 'objective' social world in advance so that it is able to assume, to play in it the role of the fragile, innocent and passive victim” (245). Žižek first describes the mother:

Let us take the care of the suffering mother as the 'pillar of the family': all other members of the family — her husband, her children — exploit her mercilessly; she does all the domestic work and she is of course continually groaning, complaining of how her life is nothing but mute suffering, sacrifice without reward. The point, however, is that this 'silent-sacrifice' is her imaginary identification: it gives consistency to her self-identityif we take this incessant sacrificing from her, nothing remains; she literally 'loses ground'. (245)

Žižek's tone in his discussion of the mother suggests a falsity in the mother's suffering or that in some way her suffering is not in fact real. As Faulkner's Addie shows, the mother's suffering results from violent ideological acts that relate directly to her social situation. Žižek's assessment implies that the mother is everywhere complicit in her "imaginary identification" but does not consider the very real conditions of existence for the mother. Would Žižek apply such an oversimplification to the desires of the patriarch? Would his persistent vocalization make his identification any less imaginary? 
Žižek goes on to suggest that the "sacrificing mother" is an example of "Lacanian communication" where the mother receives the message she sends out (as sacrificing) in an inverted form. Žižek's solution is simple: "What the poor mother must do, if she wants to liberate herself effectively from this domestic enslavement, is to sacrifice the sacrifice itself-to stop accepting or even actively sustaining the social network (of the family) which confers on her the role of exploited victim" (245). Žižek’s solution is perfectly logical and might I even say "reasonable" (which is a response of which Kant would approve). The mother must give up her sacrifice, but this simple idea of release can only be accomplished through logic or reason and not through emotion. Žižek's solution does not account for how emotional connection might require sacrifices of the mother or of any figure in order to appease the happiness of others. The mother's constantly sacrificing figure is a problem, but is the onus solely on the mother? The mother should simply give up her sacrifice, but this actually creates a larger ethical problem. Why not expect others to sacrifice more rather than the mother sacrifice all, even her sacrifice?

Žižek's final conclusion is that the mother actively pursues her symbolic identification and receives a narcissistic pleasure from playing the victim. In his assessment, Žižek reduces the mother to a coy figure who manipulates others through her victimization and sacrifice. Finally, Žižek moves to suggest that the very problem of the mother is intersubjectivity: "[B]ut her [the mother's] real identification is with the formal structure of the intersubjective field which enables her to assume this role. In other words, this structuring of the intersubjective space (the family network) is the point of her symbolic identification, the point from which she observes herself so that she appears to herself likeable in her imaginary role" (246). Žižek's language implies that the mother creates an intersubjective space that is used for her manipulation; she is the victim of her own narcissistic desire to identify with her imaginary role. Žižek may point to 
the family as an intersubjective space, but is it an ethical one? In fact, what I would suggest is that the modernist authors in this study actually challenge Žižek's very construction of the sacrificing mother and reveal that family structure, and especially parents, must be reconsidered. Žižek's text, written half a century after the "end" of modernism, reiterates the same Victorian notions of motherhood that these modernists consistently problematize. Addie Bundren and Ruth Wilcox are victims, but they derive no pleasure from their sacrifice; their narratives suggest that the victimization of the mother is in fact a key problem of modern society.

More importantly, these modernists challenge the reification of the father figure as the patriarch and in many instances, suggest that an opening up of the space between these polarized parental figures is a solution to both victim and sacrifice. The mother as sacrificial figure has been a key point of discussion since second wave feminism. Key figures from this movement either refused motherhood altogether or actively "sacrificed the sacrifice" as Žižek articulates; however, forty years later, the daughters of these mothers of feminism openly critique their decisions. By the 1990s, the cry of feminism was the achievement of "having it all"-sacrificing neither the desire for a career nor the want of a family. Despite this, the mother continues to sacrifice for both family and career. Considering this shift in perspective, the very term "feminism" has come to connote an extremist position that demonizes men. In reality, the lived lives of women suggest that there is something important in sacrifice-for a child or for others.

Every year, at the Modernist Studies Association Conference, there is a panel on the state of feminism in Modernist Studies. Typically, in this roundtable, scholars decry the disappearance of feminism, and the theorists (predominantly male) that I complicate in this study reveal the erasure of feminist voices from the theoretical canon. From Žižek to Agamben to Edelman, gender has explicitly lapsed from their critique, and more importantly, they fail to give 
credit to how "abjection" is a central definer of the mother. What is perhaps most frustrating about this trend in literary theory is their refusal to claim feminist work as important or in any way contributing to their own ideas. And this erasure reveals a larger trend in the academy itself - as feminist theory is no longer taught in favor of gender and queer theory. The foundational "feminist" critics that are now often taught in graduate school start with Judith Butler and Eve Sedgwick - as if Kristeva, Irigaray, and Cixous's essentialist notions have nothing to offer current theoretical debates. In reality, the problem of feminism is that it has in some ways done what it set out to do: made gender and sex discrimination more visible. At the same time, the visibility and the ordinariness of feminist or gender criticism has actually resulted in its invisibility. Feminism has slowly been incorporated into modern life and much of the debt is owed to the "suffering mother"- - both those who refused to suffer any longer (as in the 1970s) and those who wanted it all (as in the 1990s). And now, we enter the current space of feminism, and ironically, the changes can most obviously be seen in the realm of parenting-as women refuse to sacrifice all of their wants and desires and instead insist that men should do some sacrificing too. In essence, this project responds to the current changing gender landscape and reveals that perhaps the problem of modern society is that we need a little more sacrifice and much more empathy for all the others who surround us. 


\section{Endnotes}

\section{Chapter One}

${ }^{1}$ I draw attention to this difference, because Ezra Pound's, T.S. Eliot's, and Wyndham Lewis's aesthetics are often assumed to be "the" aesthetic practice of modernism. Although there are similarities between poetic practice and prose style during modernism, there are also key differences in terms of the development and representation of character and subjectivity that are represented via different aesthetic practices. For a larger discussion of modernist aesthetics, see Terry Higgins's The Modernist Cult of Ugliness and Leon Surette's The Birth of Modernism, and Hugh Kenner's The Pound Era.

${ }^{2}$ Lawrence discusses his counter theory to Freudian psychoanalysis in Psychoanalysis and the Unconscious and Fantasia of the Unconscious. Lawrence articulates a physical connection to psychology that expresses itself through the body, especially the gut and bowels.

${ }^{3}$ In Virginia Woolf and the Problem of the Subject, Makiko Minow-Pinkney explores Virginia Woolf's response to Freud's construction of the psychoanalytic subject in her novels. MinowPinkney focuses specifically on Woolf's feminist response, creating a narrative form that explores androgynous constructions of the subject. Woolf's aesthetic practice reflects a feminist politics: "Far from being a flight from social commitment into an arcane modernism, Woolf's experimental novels can...best be seen as a feminist subversion of the deepest formal principles — of the very definitions of narrative, writing, the subject—of a patriarchal social order" (Minow-Pinkney x).

${ }^{4}$ I would suggest that birth has typically been left out of the discussion of the sublime, because, as Freeman has pointed out, this discourse has been sculpted by men who implicitly engage in a 
gendered binary in their discussions of the sublime - especially associating the beautiful with the feminine and the sublime with the masculine.

${ }^{5}$ Barbara Claire Freeman, Patricia Yaeger, and Ann Mellor have often made this assumption in their work. However, Mellor does address "ideological cross-dressing" as regards John Keats and Emily Bronte in her final chapter of Romanticism and Gender, but this chapter does not focus on the sublime specifically or exclusively.

${ }^{6}$ The younger mothers in these texts, such as Helen in Howards End and Dewey Dell in As I Lay Dying, generally are not married and so escape the confines of marriage that these texts critique. As a result, I will not focus on them to any great extent in the dissertation; however, I will acknowledge the distinction between the younger parents versus their older counterparts.

${ }^{7}$ Simon Joyce suggests that modernists had a conflicted way of representing the Victoriansboth acknowledging the symbolic meaning of the world while often undermining such a standard idea of the Victorian (34).

${ }^{8}$ This argument has most often been made in regard to Woolf's work, but it has also been used to discuss the work of Lawrence and Forster. However, Faulkner's Addie is a figure that is not often included in this type of discussion. For critical discussions of Woolf on this subject, see Jane Marcus. For perspectives on Lawrence's work, see Judith Ruderman. And, for critical work regarding Forster, see Kerstin Elert.

${ }^{9}$ The most well-known critics who espoused this perspective are Sandra Gilbert and Susan Gubar in their work No Man's Land. Marianne DeKoven's work on sous rature also reflects an essentialist approach to gender. More recent work by Lesley Higgins has looked at the masculinist attitudes of major male modernist critics like Ezra Pound and T.S. Eliot. 
${ }^{10}$ Recently, critical work on male authors has shown a shift in perspective that reconsiders these male writers in their historical and social context. See Cassandra Laity and Christine Froula.

${ }^{11}$ Ian Watt details the rise of the novel, especially the white, middle-class, domestic novel, during the eighteenth century. In The Rise of the Novel, Watt details the common characteristics of the newly emergent novel genre as well as the historical and social context that lead to its popularity. Watt connects the rise of the realist novel to philosophical discussions of the Cartesian subject (Watt 12). The novel form arises at the same time that the modern subject emerges in political and philosophical discourse.

12 Nancy Armstrong argues that the novel form reflects political shifts through the domestic sphere; changes in domestic organization reflect different political ideologies of the eighteenth and nineteenth century. Armstrong links the domestic, the novel genre, and white middle class ideological constructions of identity.

${ }^{13}$ For a detailed discussion of the rise of novel as a genre, see Michael McKeon's The Origins of the English Novel, 1600-1740.

${ }^{14}$ E.M. Forster is the novelist most associated with the rise of humanism in the early twentieth century. Combining the political aims of first wave feminism with his queer politics, Forster explored the relationship between writing, humanism, and feminism.

${ }^{15}$ For an introduction to modernist aesthetics in poetry, see Theorists of Modernist Poetry: T.S. Eliot, T.E. Hulme, and Ezra Pound by Rebecca Beasley.

16 In The Formation of $20^{\text {th }}$-Century Queer Autobiography: Reading Vita Sackville-West, Virginia Woolf, Hilda Doolittle, and Gertrude Stein, Georgia Johnston examines the influence of Sigmund Freud on queer autobiographies by female writers: "Violation and change emerge from 
literary struggles over sexual subjectivity. This is a rich area, particularly because of modernism's fascination with the subject and object, and because of autobiography's concomitant conflation, shifting, and deviance in the correspondence between writer and written 'I"' (2). For Woolf, Johnston argues that "A Sketch of the Past" parodies the case studies of Freud, employing a "double reading" that understands lesbian code (78).

${ }^{17}$ For a detailed discussion of Freud and feminism, see the edited collection The (M)other Tongue, edited by Claire Kahane, Shirley Nelson Garner, and Madelon Sprengnether.

18 Georgia Johnston examines how Freud constructs his case studies through memory and reflection, an act of representation; she writes, Freud's "use of previous texts as models for his sexual understanding, even if only to reach a wider audience, makes that understanding seem to be discovered truth, since it fits 'scientific' observations into existing cultural patterns. Instead of discovering, however, Freud mystifies the relationships between text, Nature, and culture, eliding the three to support his theories" (52).

${ }^{19}$ For instance, if an object is smooth, it is beautiful; if it is rough, it is sublime. Lightness, softness, and proportion are all aspects of the beautiful; whereas, darkness, roughness, infinity are all aspects of the sublime.

${ }^{20}$ Kant writes of emotion, "Emotion, a sensation where agreeableness is brought about only by means of a momentary inhibition of the vital force followed by a stronger outpouring of it, does not belong to beauty at all. But sublimity (with which the feeling of emotion is connected) requires a different standard of judging from the one that taste uses as a basis. Hence a pure judgment of taste has as its determining basis neither charm nor emotion, in other words, no 
sensation, which is [merely] the matter of an aesthetic judgment" (72). For Kant, emotion connects to sublimity while disinterestedness remains in the realm of judgment.

${ }^{21}$ For Kant, The sublime experience is a balance between imagination and reason: "The feeling of the sublime is a feeling of displeasure that arises from the imagination's inadequacy, in an aesthetic estimation of magnitude, for an estimation by reason, but is at the same time also a pleasure, aroused by the fact that this very judgment, namely, that even the greatest power of sensibility is inadequate is [itself] in harmony with rational ideas, insofar as striving toward them is still a law for us" (114-115).

${ }^{22}$ Barbara Claire Freeman proposes a feminine sublime that is not a "rhetorical mode nor aesthetic category" but an encounter with otherness that is "excessive and unrepresentable" (2).

23 Thomas Weiskel's argues for an "egotistical sublime" associated with the male romantic poets - although he traces this tradition through the discourse of Burke and Kant.

24 Anne K. Mellor writes, gothic novelists accept "the identification of the sublime with the experience of masculine empowerment. But they explicitly equate this masculine sublime with patriarchal tyranny. Their novels expose the dark underside of the doctrine of the separate spheres, the sexual division of labor, and the domestic ideology of patriarchal capitalism....By moving the exercise of the sublime power into the household, the female Gothic domesticates the sublime as paternal transgression-represented as father-daughter incest - that is everywhere most monstrous and most ordinary.

${ }^{25}$ Lacan discusses the "other" in his theorization of the mirror stage in infants, and as it regards women specifically, Lacan argues for symbolic power associated with the "phallus" rather than 
an inherent power based on biological sex in "The Signification of the Phallus." He specifically discusses woman as "other" in "God the Jouissance of the Woman."

${ }^{26}$ Thomas's Weiskel's The Romantic Sublime: Studies in the Structure and Psychology of Transcendence is particularly canonical in emphasizing the "ego" as the foundational component of the sublime, particularly the masculine romantic sublime.

${ }^{27}$ Thomas Laqueur offers a detailed history of the relationship between biological sex and the construction of gender from Greek civilization to the early twentieth century. Cristina Mazzoni, Lisa Rado, and David Seelow briefly look at the role sexology and psychoanalysis plays in the understanding of gender at the turn-of-the-twentieth century in the development of modernist literature.

${ }^{28}$ Recent work in masculinity studies has drawn attention to the destabilization of masculinity in the early twentieth century. Ben Knights draws attention to the assumed invisibility of white masculinity due to theoretical discussions which see white masculinity as possessing the most power and as a result not a viable subject of analysis in terms of gender or race. Peter Middleton examines how discourse fails to address masculinity appropriately, because it reiterates the same dynamics that were used in the oppression of women. Middleton suggests that an "inward gaze" should be used in discussing masculinity: "masculine self-aggrandizement, in which masculine subjectivity fantasizes hypermasculine exploits, inflates itself into sublimity" (9). He argues that reflexivity fails for men, because it does not offer a way for men to reflect on constructions of masculinity that are made invisible by being understood as the "norm." 
${ }^{29}$ The shift in women's rights starts in the late Victorian time period and continues into the early twentieth century. Historical discussions of this change include Shani D'Cruze's "Women and the Family," Sheila Jeffrey's "Women and Sexuality," and Rowbotham's opening chapters.

${ }^{30}$ Joyce's overall argument reconsiders evaluations of and reflections on Victorians as either good or bad, but rather, as a complex social system, which requires complex navigations by individual subjects. Joyce also concisely points out the similarities between Modern and Victorian: What results from Strachey's use of jest as a rhetorical strategy that constantly subverts expectations is not "a simple reversal of polarities that might claim that the modern is somehow better-truer to its convictions, say, or more complex - than the Victorian, but the larger question of whether we can fully distinguish the Victorian from the modern, especially given the former's capacity for self-contradiction" (38).

${ }^{31}$ The rhetoric employed by Sanger and many other birth control enthusiasts reflected eugenicist attitudes of "racial purity" that complicate the motives of the movement as invested in white, heteronormative culture; however, this is outside the scope of this project. For a more detailed discussion of this topic, see Allison Berg's Mothering the Race: Women's Narratives of Reproduction, 1890-1930.

\section{Chapter Two}

${ }^{1}$ Drawing on the title reference to Agamemnon, Doreen Fowler explores Addie as invoking a story of matricide and a mother's revenge. In particular, Addie creates her revenge as a "challenge to paternal structures of meaning" (Fowler 50). She goes on to argue that Faulkner "rewrites a dominant myth of our culture, the mythic identification of the mother's body with castration and death, and he allows the dead mother to speak" (Fowler 50). 
2 Amy Louise Wood invokes Luce Irigiaray's concept of "mimicry" in order to argue that Addie "manipulates and distorts those roles [mother, adulteress] and their meanings to expose her society's empty constructions of motherhood, love, religion, and language, creating a sense of self and negotiating power for herself separate from them" (100). Doreen Fowler explores Addie through the concept of matricide and revenge (as noted above). Karen R. Sass suggests that Addie's attempts to dismantle patriarchal language affect all of her children in often tragic ways (9). In essence, As I Lay Dying is the text is of particular importance because of Addie's voice.

${ }^{3}$ In addition to Amy Louise Wood and Karen R. Sass, Deborah Clarke, Marc Hewson, and Paul S. Nielsen also explore the way language functions in the novel through Addie's passage. Clarke argues, "Faulkner's own awareness that the mother can rule in both the semiotic and the symbolic, that the imprint of her body can be traced through a focus on the corporeal and the ways that it can impede individual autonomy. Her uncanny presence and absence destabilizes the world of his fiction, allowing him to examine the roots of its being" (15). Hewson suggests that it is possible "to read her [Addie] instead as an active force in their [her children's] lives, teaching them (especially the male children who might be more vulnerable) to combat the oppressive and ultimately negative philosophy of the patriarchy in the book. Though she dies early on and receives only one opportunity for direct speech, the importance of intuitive love and of language's inadequacy to express it that she instills in her sons maintains Addie's place at the novel's core" (551). Nielsen points out that Addie's passage is the most obsessed with language, showcasing her "deep suspicion and frustration with the referentiality of all language" (34). He writes, "To listen to Addie tell it, life is a struggle with the words as much a with the deeds, and 
in the telling the struggle is to make the word full of meaning, to make the word one with the deed" (34).

${ }^{4}$ Harriet Hustis details discussions of Addie in Faulkner scholarship, especially as she is often identified as either a mother, a wife, or a corpse in critical readings of the text.

${ }^{5}$ For a discussion of the importance of morality in the construction of women's gender roles in early nineteenth century America, see Nancy F. Cott's The Bonds of Womanhood: 'Woman's Sphere' in New England, 1780-1835. For a discussion of women's gender roles in the American South, see Jane Turner Censer's The Reconstruction of White Southern Womanhood, 1865-1895.

${ }^{6}$ Tamara Slankard looks at the function of corpses in modernism (and Addie's corpse in particular) in a way that does not focus on how one deals with death: "Corpses that are overvalued, corpses that stand in symbolically or metonymically for other objects, other concepts, other narratives, other ideologies—fetishized corpses-force us to rethink notions of modernism and modernity because they reveal characteristics of regional modernism distinctly and explicitly at odds with old and new attempts at definition" (7). Deborah Clarke writes of Addie's body: "A maternal corpse replaces maternal absence. Faulkner sets up two creative paradigms in the novel: mothering and speaking. What he does not do, however, is to set them in opposition to each other, with women as literal and men as figurative creators. After all, Addie's voice is strong enough to be heard through her coffin, and her son Darl achieves, at times, a kind of non-linguistic 'feminine' intuition" (35). Erin E. Edwards argues that the corpse "becomes a more abstract and ubiquitous presence through a figurative corporealizing and cadaverizing of both the natural world and characters' perceptual, subjective experiences" (739). 
${ }^{7}$ Luce Irigaray uses Lacanian psychoanalysis in Speculum of the Other Woman in order to critique Freudian psychoanalysis and suggest the construction of écriture feminine that defies patriarchal language.

${ }^{8}$ Karen R. Sass and Deborah Clarke explore the novel uses Lacanian psychoanalysis.

${ }^{9}$ Doreen Clarke traces the relationship between Addie's image of the "jar" and its relationship to her "unvirgin" body. She sees both as reflecting the use of patriarchal language (Clarke 39).

${ }^{10}$ The idea that women are barred from artistic creativity due to their procreative capacities has often been linked to the development of the childbirth metaphor employed by male artists. Susan Stanford Freidman has traced this relationship in "Creativity and the Childbirth Metaphor.

\section{Chapter Three}

${ }^{1}$ Although Kant's overall discussion of the sublime is often dismissed as a transcendental one, Paul de Man discusses the larger implications of Kant's sublime as "informing us, like the beautiful, about the teleology of nature, it informs us about the teleology of our own faculties, more specifically about the relationship between imagination and reason" (73). De Man continues to discuss what the sublime attempts to accomplish: "It follows...that whereas the beautiful is a metaphysical and ideological principle, the sublime aspires to being a transcendental one" (73, my emphasis). As de Man so succinctly discusses, Kant's sublime may appear to be transcendental but the inability of the sublime to achieve that transcendental explanation actually makes it part of a larger ideological structure. Thus, the Kantian sublime is invested in an examination of ideological structures while attempting to explain its transcendence. Ultimately, it is the connection of reason to ideas of moral law that allows the 
Kantian sublime to succeed in its relationship between subject and object; it emphasizes the mind's ability to recognize its own inabilities.

2 Žižek describes the following process in the realization of the sublime using Lacan's theories: "That is to say, with Kant the sublime designates the relation of an inner-worldly, empirical, sensuous object to Ding an sich to the transcendent, trans-phenomenal, unattainable Thing-initself. The paradox of the Sublime is as follows: in principle, the gap separating phenomenal, empirical objects of experience from the Thing-in-itself is insurmountable - that is, no empirical object, no representation of it can adequately present the Thing (the suprasensible Idea); but the Sublime is an object in which we can experience this very impossibility, this permanent failure of the representation to reach after the Thing. Thus, by means of the very failure of representation, we can have a presentiment of the true dimension of the Thing” (Žižek 229).

${ }^{3}$ In a more political definition, Judith Halberstam uses queer to refer to "nonnormative logics and organizations of community, sexual identity, embodiment, and activity in space and time" (6). In her work, Halberstam is focused specifically on transgendered bodies and communities, which emphasizes how queer time and space can be explored; her work shifts away from questions of aesthetic representation.

${ }^{4}$ For Edelman, "Sinthomosexuality...scorns such belief in a final signifier, reducing every signifier to the status of the letter and insisting on access to jouissance in place of access to sense, on identification with one's sinthome instead of belief in its meaning” (Edelman 37). In his assessment of Kant's project regarding aesthetic judgment, de Man also insists on the importance of the letter: "The bottom line, in Kant as well as in Hegel, is the prosaic materiality 
of the letter and no degree of obfuscation or ideology can transform this materiality into the phenomenal cognition of aesthetic judgment" ("Phenomenality" 90).

${ }^{5}$ Žižek interprets the Kantian discussion of pleasure and displeasure in the sublime as preceding what Lacan determines as the sublime object. The inability of representation to "reach after the Thing" is "why an object evoking in us the feeling of Sublimity gives us simultaneous pleasure and displeasure: it gives us displeasure because of its inadequacy of the Thing-Idea, but precisely through this inadequacy it gives us pleasure by indicating the true, incomparable greatness of the Thing, surpassing every possible phenomenal, empirical experience" (Žižek 229).

${ }^{6}$ Robert K. Martin argues that Forster "works toward a reorganized vision of human relations in order to allow continuance without physical conception, to provide continuity without heterosex and without nuclear family parenting" (256). In a similar move, Jeane N. Olson also argues that Forster revisions the nuclear family and the extended family in Howards End (360).

${ }^{7}$ For discussions of Victorian maternal death, see Patricia Jalland's Death in the Victorian Family and Elisabeth Bronfen's Over Her Dead Body: Death, Femininity, and the Aesthetic. For a discussion of the Victorian gendered body and aestheticism, see Kathy Alexis Psomiades's Beauty's Body: Femininity and Representation in British Aestheticism. On death and modernism, see Alan Warren Friedman's Fictional Death and the Modernist Enterprise.

${ }^{8}$ Ariela Freedman argues that modernist novels engage in a substitution of a death of a female character for a male character: “A man's death replaces a woman's death and in doing so gains narrative primacy as the male character loses the effect of narrative agency. My primary concern will be with E.M. Forster's Howards End, which associates death with male subjectivity and concomitantly predicates an excess of female agency, women characters able to predict or 
determine not only their own narrative futures but even, to some degree, the event of the male other's death" (41). In the case of Howards End, Mrs. Wilcox's death becomes the event which precipitates Leonard Bast's death at Howards End and gives Margaret the agency to speak; however, this argument ignores the importance of Mrs. Wilcox's death in the novel and implies that her death is of lesser importance than that of Leonard's (or a man's).

${ }^{9}$ As Jeane N. Olson notes, this can also be seen in D.H. Lawrence's The Rainbow. Of Howards End, Olson writes that Forster "visualized a more egalitarian, inclusive family that would be a fertile seedbed where all its members, deeply rooted in the past and securely connected with their own emotions, might be equally enriched by energizing currents from the outside" (347).

${ }^{10}$ For a larger discussion of gender in Forster's work, see Bonnie Blumenthal Finkelstein's Forster's Women: Eternal Differences. For discussions of legitimacy related to heirs, see Catherine O. Frank's “Fictions of Justice: Testamentary Intention and the (Il)legitimate Heir in Trollope's Ralph the Heir and Forster's Howards End.

${ }^{11}$ For Burke, "Infinity" is one of his empirical descriptions of the sublime, because the mind conceives of the infinite as having no boundaries (115). In developing Burke's idea of the infinite as part of the sublime, Kant suggests that reason is the mental faculty that allows the mind to conceive of the infinite. He writes, "Reason makes us unavoidably think of the infinite (in common reason's judgment) as given in its entirety (in its totality)" (111). For Kant, the infinite helps to create the sublime experience: "If the human mind is nonetheless to be able even to think the given infinite without contradiction, it must have within itself a power that is supersensible, whose idea of a noumenon cannot be intuited but can yet be regarded as the substrate underlying what is mere appearance, namely, our intuition of the world" (111). 
${ }^{12}$ In her chapter on Howards End, Ariela Freedman notes Forster's use of books in Leonard's death scene.

${ }^{13}$ Despite these attempts to connect, Leslie White argues that Howards End utopian ending is destabilized by the moments of disconnection in the text: "Forster does want connection, but the utopian vision of Howards End is destabilized by his ambivalence (as well as his inchoate aesthetic positions) regarding the utility of the exceptional person in a culture threatening or unsympathetic to the dynamical, imaginative life. The vital disconnection that Forster could finally articulate in his critical writings is prefigured in the various 'failures,' in the compromised lives and strained, implausible connections of Howards End" (57).

${ }^{14}$ Jeane N. Olson argues that Forster envisions a modern notion of family in Howards End that reflects contemporary changes in family structure (347).

\section{Chapter Four}

${ }^{1}$ Feminist theory from the 1970 s forward has documented the ideological roles of mothers. In particular, Julia Kristeva has explored the conflict between the Madonna/whore binary regarding women, showing the importance of the good mother in Western culture. More recently, Ann Taylor Allen has documented the ideology of motherhood during the twentieth century, analyzing what she terms the "maternal dilemma" as a conflict between individual subjectivity and a woman's expected social role in Western Europe (1).

${ }^{2}$ For a discussion of Lawrence's position within the academy in terms of his gender and politics, see Gary Adelman and Robert Burden, who both attempt to redeem Lawrence for his misogyny. Also, see Peter Balbert's D.H. Lawrence and the Phallic Imagination; however, Balbert makes some apt points about feminism's interpretation of Lawrence, but his overly aggressive tone 
toward feminism showcases his own investment in maintaining masculinist discourse as regards gender. Better examples of a reconsideration of gender in Lawrence is seen in the work of Anne Fernihough, who examines Lawrence in terms of his aesthetic practice related to his understanding of philosophy, and Stephen P. Clifford, who examines issues of masculinity in Lawrence's work.

${ }^{3}$ Much of the criticism on The Rainbow focuses exclusively on the idea of progression and is mainly concerned with Ursula, a modern woman. Hilary Simpson, Carole Dix, Peter Balbert, Beatrice Monaco, and Joyce Piell Wexler are just a few of the critics who emphasize Ursula as the culmination of the novel's designs. In this way, much of the criticism of The Rainbow insists on seeing a fluid progression throughout the generations of Brangwens; whereas, I draw attention to the differences in the two earlier generations of Brangwen's that result in Ursula's feelings of alienation and fragmentation. In my reading of the text, the solution lies in the past rather than the future.

${ }^{4}$ This is not surprising since reproduction is central to the rhetoric of the Women's Rights Movement at the turn of the century. Allison Berg analyzes the rhetoric of the women's rights movement from the turn-of-the-century fixation on "racial progress." She contrasts this rhetoric with readings of narratives like The Awakening that question the "apparently natural relationship between female biology and racial destiny, challenging traditional ideas about gender, sexuality, race, and motherhood" (Berg 2001).

${ }^{5}$ Carolyn G. Heilbrun laid the foundation for work on androgyny and modernism in Toward a Recognition of Androgyny. More recent work by Lisa Rado shows a connection between the sublime and modernist imaginings of an androgynous authorial voice as a result of the work by 
sexologists. For Lawrence in particular, Mark Kinkead-Weekes comments on the influence of bisexuality and androgyny on the construction of Lawrence's authorial persona (161). David Seelow details the relationship between Lawrence and sexology.

6 For discussions about Lawrence's familiarity with psychoanalysis, see the Cambridge biography by John Worthen, Mark Kinkead-Weekes, David Ellis, and David Seelow.

${ }^{7}$ Kant writes of judgment: "Judgment will bring about a transition from the pure cognitive power, i.e., from the domain of the concepts of nature, to the domain of the concept of freedom, just as in its logical use it makes possible the transition from understanding to reason" (Critique of Judgment 18). In other words, judgment is what allows the discernment of the beautiful from the sublime, which reflects a shift from understanding to reason. Judgment becomes the defining characteristic of Kant's aesthetic, because it reflects the ability of the subject to deem something or an experience as beautiful or sublime.

8 Lawrence writes about the importance of "blood" and the body in his theorizations on psychoanalysis and sexuality in Psychoanalysis and the Unconscious and Fantasia and the Unconscious.

9 Barbara Claire Freeman details the sacrifice of the feminine in the Kantian sublime's construction of the imagination. She argues that the Kantian construction of the sublime participates in patriarchal discourses that require the sacrifice of the feminine.

${ }^{10}$ For a detailed discussion of the "separate spheres" doctrine, see the edited collection No More Separate Spheres! by Cathy N. Davidson and Jessamyn Hatcher.

11 Peter Zima examines the collapse of the sublime into the beautiful while Terry Higgins explores the "modernist cult of ugliness" as collapsing the ugly into the beautiful. 
${ }^{12}$ Barbara Claire Freeman argues that Kant sacrifices the imagination, which is gendered as feeling, in his writing on the sublime. In a similar manner, Lawrence reads emotion, which is also gendered as feminine, as sacrificed to Kant's reason in his broader aesthetic theorizations.

${ }^{13}$ Critics like Peter Balbert, and Stephen P. Clifford have thoroughly established the tempestuous relationship between Anna and Will, so I focus on the root cause of this battle rather than an extensive discussion of their battles.

${ }^{14}$ Carl Krockel reads Lawrence as opposing Goethe, Schopenhauer, and Wagner in terms of the primal wille of individuals, because they "fail to affirm the individual in his relation to society" (16). For Lawrence, the "will" is complicated process that includes the individual's interactions with social norms and society. Lawrence chooses to read Nietzsche's reformulation of the primal wille as the "will to power," which combats Romantic pessimism, and allows him to propose a libidinal impulse in human interactions that combats power relations (Krockel 16).

\section{Chapter Five}

${ }^{1}$ Lionel Trilling employs this reading of Mrs. Ramsay in the 1960s, and despite feminist responses to male critical responses to Woolf's work, Mrs. Ramsay is still often linked to the domestic even if she is not considered a domestic goddess. In her comparison of Cam and Mrs. Ramsay, Shannon Forbes explores Mrs. Ramsay's role as Angel in the House. Denise Marshall also explores the construction of the Angel and the Patriarch in the novel. Also, see Jane Lilienfeld's discussion of Mrs. Ramsay in "The Deceptiveness of Beauty: Mother Love and Mother Hate in To the Lighthouse." 
${ }^{2}$ Denise Marshall looks at Woolf's use of the comedic element in her critical and fictional writing of Victorian mother and father figures. Emily Dalgarno explores how Mr. and Mrs. Ramsay function as symbols in Virginia Woolf and the Visible World (24-25).

${ }^{3}$ Hermione Lee suggests that Woolf's writing of To the Lighthouse is cathartic as it allows her to explore her relationship with her parents.

${ }^{4}$ Jane Lilienfeld, Phyllis Rose, Sara Ruddick, Jane de Gay, and Paula Bennett have explored Lily's pivotal position as representing the mother and imply that Lily functions in the novel as a surrogate daughter to Mrs. Ramsay.

${ }^{5}$ Kari Elise Lokki's analysis of Orlando reveals a comic sublime mode in Woolf: “Orlando, in fact, brilliantly embodies the seemingly contradictory political and aesthetic theories of $A$ Room of One's Own in a vision of the comic sublime that celebrates a mystical union of human sexuality and spirit and radically rewrites the Romantic sublime of Kant and Wordsworth. This mock sublime embodies Woolf's modernist, feminist perspective and challenges the dualisms at the very heart of the traditional sublime aesthetic" (236).

${ }^{6}$ For a discussion of beauty related to ethics in Woolf, see Pamela L. Caughie's "How Do We Keep Desire from Passing with Beauty?”.

7 Suzanne Clark documents the controversy over sentimentalism, a technique which wolf embraced in her writing, in Sentimental Modernism: Women Writers and the Revolution of the Word.

${ }^{8}$ Georgia Johnston explores the connection between early twentieth century autobiography and developments in Freudian psychoanalysis. Of Woolf's "A Sketch of the Past," Johnston explores Woolf's use of parody as regards Freud: 'She [Woolf] also positions her 'I' ironically 
by giving herself an Oedipal position within the family and by taking herself out of that position simultaneously. Woolf uses a position she calls 'Outsider' to expose the authority and expectations of the patriarchal society as a foil against which to play with patriarchal positions" (82). Carolyn Dever explores Freud's use of the Victorian "maternal death plot" as the basis of his formulation of the Oedipus Complex. Ellen Bayuk Rosenman looks at Woolf's relationship to the mother as reflecting a preoedipal state (21) and Woolf's exploration of regression in To the Lighthouse (46). Finally, Christine Froula explores Woolf's use of the triangle in Lily's painting as representing Freud's Oedipal triangle (144).

${ }^{9}$ Cite Hermione Lee here

${ }^{10}$ Insert endnote on Bloomsbury and Freud

11 Many feminist critics comment on this critical trend in Madelon Sprengnether's edited collection The (M)other Tongue: Essays in Feminist Psychoanalytic Interpretation. In particular, see the following essays: See Jane Gallop's “The Father's Seduction," Madelon Sprengnether's "Endorsing Oedipus: Freud and Dora," and Coppelia Kahn's "The Hand That Rocks the Cradle: Recent Gender Theories and Their Implications.”

${ }^{12}$ In her diary entry from "Saturday 2 December 1939," Woolf outlines her reasons for turning to Freud in the first place: "Began reading Freud last night; to enlarge the circumference. to give my brain a wider scope: to make it objective; to get outside. Thus defeat the shrinkage of age" (Diary Vol. 5 248, my emphasis).

${ }^{13}$ In To the Lighthouse, the autobiographical approach is tempting, because Woolf and her sister, Vanessa Bell, constantly comment in letters and diaries about the connection between their own mother and father, the Stephens, and the Ramsays. In "A Sketch of the Past," Woolf notes that 
during the writing of To the Lighthouse, "the presence of my mother obsessed me. I could hear her voice, see her, imagine what she would do or say as I went about my day's doings" (80). As the passage continues, Woolf cites her mother as an "invisible presence" that influences the development of identity ("A Sketch" 80). This obsession with her mother leads Woolf to write To the Lighthouse in an "involuntary rush" ("A Sketch" 81). Woolf continues, "But I wrote the book very quickly; and when it was written, I ceased to be obsessed by my mother. I no longer hear her voice; I do not see her" (“A Sketch" 81). In this recreation of the writing of To the Lighthouse in her memoir, Woolf sees the writing of the novel as cathartic, a way of examining the loss of her mother. Hermione Lee, Ellen Bayuk Rosenman, and Roberta Rubenstein have read Woolf's autobiographical and biographical material as evidence that Mrs. Ramsay is Mrs. Stephen.

I acknowledge that the writing of To the Lighthouse has a cathartic function for Woolf in accepting her loss, but it is her sister, Vanessa Bell, who explicitly links Mrs. Ramsay to Mrs. Stephen. It is she that sees a strictly autobiographical reading of the novel, not Woolf. In a diary entry, Woolf writes a plot synopsis of To the Lighthouse, "to have father's character done complete in it; \& mother's; \& St Ives; \& childhood; \& all the usual things I try to put in-life, death \&c. But the center is father's character, sitting in a boat, reciting We perished, each alone, while he crushes a dying mackerel" (Diary 3: 18-19). In this passage from her diary, Woolf writes that she wants to present the character of her father and mother; it implies that people, place, and time influence her writing, but it does not show that Mr. Ramsay or Mrs. Ramsay are in fact exact representations of her mother and father. More importantly, Woolf employs the term "character," which implies an intangible quality that is representative of a person. It is 
Vanessa who draws the connection between Mrs. Ramsay and Mrs. Stephen that so many critics have cited as evidence for their autobiographical readings of Mrs. Ramsay; Vanessa writes, “ in the first part of the book you have given a portrait of mother which is more like her to me than anything I could ever have conceived possible. It is almost painful to have her so raised from the dead" (Bell, Letters 317). Despite Vanessa's interpretation, Woolf's chooses to write a novel rather than a memoir about her personal experiences. The choice of genre expresses a clear authorial intent that wants to separate To the Lighthouse from strict autobiography, a move that may be a way of distancing herself from the biographical approaches of Leslie Stephen's writing. Ultimately, Woolf insists on drawing on her family and St. Ives for inspiration; whereas, it is others (Vanessa, literary critics) that read the novel as a representation rather than an impression of Woolf's childhood and her parents.

${ }^{14}$ Recent critical work on Woolf with its emphasis on global modernism still points to a feminist politics that envisages less demarcated social barriers. In terms of nationality, Jane Garrity argues that Woolf uses the maternal in order to revise imperialist discourse. For Garrity, Woolf desires a "recovery of a repressed language, one drawn from the discourses of conquest and English prehistory, that would help to shape a feminizing of national space" (247). In her exploration of the common reader, Melba Cuddy-Keane looks at Woolf's attempts to reach the “common reader." Although not an explicitly feminist interpretation, Cuddy-Keane's examination of Woolf's educational writing directed toward the "common reader" is informed by Woolf's feminist politics. Cuddy-Keane writes, "Woolf promoted the ideal of a classless, democratic, but intellectual readership, recasting 'highbrowism' as radical social practice” (2). In other words, Woolf writes to the masses through her essays in an attempt to transcend social 
barriers through education. Finally, Anne Fernald wants to move away from familial metaphors that have been the focus of feminist criticism of Woolf. In essence, Fernald diverges from essentialist readings of Woolf through familial metaphors in favor of a more nuanced analysis of Woolf that takes into account not only her radical feminist politics but also her less appealing attributes, including snobbery and racism. Fernald suggests that Woolf (and modernism more broadly) sees literary history as an act of invention rather than inheritance, removing it from the familial patterns of literary history. Considering Woolf's skepticism about literary inheritance, Fernald also considers Woolf's doubts about women's participation in the traditional public sphere (86). Fernald argues that in Three Guineas, Woolf finds the role of the spectator (typically associated with women) as an empowering position outside of the public (and patriarchal) sphere (112). In all her work, Woolf everywhere shows a new way of thinking about society that is based first upon a female position.

${ }^{15}$ For a detailed discussion of Woolf's comic tone in "Professions for Women," see Denise Marshall's "Slaying the Angel and the Patriarch: The Grinning Woolf."

${ }^{16}$ For a discussion of Woolf's exploration of Victorian parenthood in the novel, see the work of Stephen Ellis, Helen Bayuk Rosenman, and Hermione Lee.

${ }^{17}$ This is particularly true of the work of Helen Bayuk Rosenman, Roberta Rubenstein, and Carolyn Dever.

18 Pamela Caughie, Emily Dalgarno, and Jane Lilienfeld explore how beauty functions in Woolf's work, but do not consider a mother's subjectivity at any length.

${ }^{19}$ Of Lily's aesthetic, Marco Caracciolo writes, Lily's aesthetic "sidesteps the problem of time (a key concern in the formalist framework) with a leap into space. In particular, the virtual space 
that Lily Briscoe discovers on the 'other side' of her canvas enables her (and possibly the novel as a whole) to defuse the anxiety about time expressed by most characters. As we will see, the virtuality of art points to its ability not to achieve permanence...but to expand and attach meaning to our daily experience" (253).

20 There are multiple references throughout the novel to Mr. Ramsay's "genius," which is reflected through his continual quotation of Alfred, Lord Tennyson and William Cowper. As Shuli Barzilai notes, Woolf's use of quotation challenges constructions of authorship that aligns Ramsay with male ideas of authorship (23).

${ }^{21}$ For a discussion of Woolf's narrative method in the novel, see Jane Lilienfeld's " $T o$ Have the Reader Work with the Author': The Circulation of Knowledge in Virginia Woolf's To the Lighthouse and Toni Morrison's Jazz" and Angela Frattarola's "Developing an Ear for the Modernist Novel: Virginia Woolf, Dorothy Richardson, and James Joyce.”

${ }^{22}$ Ellen Bayuk Rosenman argues that Woolf needs to "recover the mother" as "one important motive for Woolf's writing" (15). She supports her argument by looking at the loss of the mother as where art originates, using To the Lighthouse as an example (Rosenman 16).

${ }^{23}$ Barbara Claire Freeman writes, "[I]n Kant's writings the imagination is gendered as feminine and that its sacrifice functions rhetorically to ensure the sublime moment, a sacrifice that is doubled in many novels — whether their authors are men or women — by scapegoating a feminine figure as a point of reference to guarantee discursive unity and the formation of autonomous, centered selves. In both cases the operation requires violence directed against women or a feminine surrogate" (69). In To the Lighthouse, Mrs. Ramsay certainly fulfills the role of scapegoat, but the fact that Lily uses the imagination in order to redeem the scapegoated figure 
suggests that Woolf does not participate in Kant's misogynistic sublime that a Freeman documents. 


\section{Works Cited}

Adelman, Gary. Reclaiming D.H. Lawrence: Contemporary Writers Speak Out. Lewisburg: Bucknell UP, 2002. Print.

Adorno, Theodor. Aesthetic Theory. Trans. Robert Hullot-Kentor. Minneapolis: U of Minnesota P, 1998. Print.

Agamben, Giorgio. Homo Sacer: Sovereign Power and Bare Life. Trans. Daniel Heller-Roazen. Stanford: Stanford UP, 1998. Print.

Allen, Ann Taylor. Feminism and Motherhood in Western Europe, 1890-1970. New York: Palgrave-Macmillan, 2005. Print.

Armstrong, Nancy. Desire and Domestic Fiction: A Political History of the Novel. New York: Oxford UP, 1987. Print.

Atkinson, Ted. Faulkner and the Great Depression: Aesthetics, Ideology, and Cultural Politics. Athens: U of Georgia P, 2006. Print.

Bahlke, George W. "The Individual and the Community in Howards End and The Rainbow." D.H. Lawrence: Literature, History, Culture. Eds. Michael Bell et al. Tokyo: KokushoKankoKai, 2005. 316-340. Print.

Balbert, Peter. D.H. Lawrence and the Phallic Imagination. New York: St. Martin's P, 1989. Print.

Barzilai, Shuli. "The Politics of Quotation in To the Lighthouse: Mrs. Woolf Resites Mr. Tennyson and Mr. Cowper.” Literature and Psychology. 41.3 (1995): 22-43. Print.

Beasley, Rebecca. Theorists of Modernist Poetry: T.S. Eliot, T.E. Hulme, and Ezra Pound. New York: Routledge, 2007. Print. 
Benjamin, Jessica. Like Subjects, Love Objects: Essays on Recognition and Sexual Difference. New Haven: Yale UP, 1995. Print.

Bennett, Paula. “The Mother's Part: Incest and Maternal Deprivation in Woolf and Morrison." Narrating Mothers: Theorizing Maternal Subjectivities. Ed. Brenda O. Daly and Maureen T. Reddy. Knoxville: U of Tennessee P, 1991. 125-138. Print.

Berg, Allison. Mothering the Race: Women's Narratives of Reproduction, 1890-1930. UrbanaChampaign: U of Illinois P, 2001. Print.

Berman, Jessica. "Ethical Folds: Ethics, Aesthetics, Woolf." Modern Fiction Studies. 15.1 (2004): 151-172. Print.

Blaine, Diana York. "The Abjection of Addie and Other Myths of the Maternal in As I Lay Dying." The Mississippi Quarterly 47.3 (1994): 419+. Literature Resource Center. Web. 13 Feb. 2011.

Blair, Emily. Virginia Woolf and the Nineteenth-Century Domestic Novel. Albany: State U of New York P, 2007. Print.

Booth, Howard J. "D.H. Lawrence and Male Homosexual Desire." The Review of English Studies. 53.209 (2002): 86-107. Print.

Bronfen, Elisabeth. Over Her Dead Body: Death, Femininity, and the Aesthetic. Manchester: Manchester UP, 1992. Print.

Broughton, Trev Lynn and Helen Rogers. Eds. Gender and Fatherhood in the Nineteenth Century. New York: Palgrave Macmillan, 2007. Print.

Burden, Robert. Radicalizing Lawrence: Critical Interventions in the Reading and Reception of D.H. Lawrence's Narrative Fiction. Amsterdam-Atlanta, GA: Rodopi, 2000. Print. 
Burke, Edmund. A Philosophical Enquiry into the Sublime and Beautiful. New York: Routledge, 2008. Print.

Butler, Judith. Bodies That Matter: On the Discursive Limits of Sex. New York: Routledge, 1993. Print.

Caracciolo, Marco. "Leaping into Space: The Two Aesthetics of To the Lighthouse." Poetics Today. 31.2 (2010): 251-284. Print.

Casey, Simon. “The Radical Individualism of D.H. Lawrence and Max Stirner.” D.H. Lawrence Review. 31.1 (2002): 7-27. Print.

Caughie, Pamela L. "How Do We Keep Desire from Passing with Beauty?". Tulsa Studies in Women's Literature. 19.2 (2000): 269-284. Print.

Censer, Jane Turner. The Reconstruction of White Southern Womanhood, 1865-1895. Baton Rouge: Louisiana State UP, 2003. Print.

Clark, Suzanne. Sentimental Modernism: Women Writers and the Revolution of the Word. Bloomington: Indiana UP, 1991. Print.

Clarke, Deborah. Robbing the Mother: Women in Faulkner. Jackson: UP of Mississippi, 1994. Print.

Clifford, Stephen P. Beyond the Heroic "I": Reading Lawrence, Hemingway, and “Masculinity". Lewisburg: Bucknell UP, 1998. Print.

Cott, Nancy F. The Bonds of Womanhood: “Woman's Sphere” in New England, 1780-1835. New Haven: Yale UP, 1997. Print.

Cucullu, Lois. Expert Modernists, Matricide, and Modern Culture: Woolf, Forster, Joyce. New York: Palgrave Macmillan, 2004. Print. 
Cuddy-Keane, Melba. Virginia Woolf, the Intellectual, and the Public Sphere. Cambridge: Cambridge UP, 2003. Print.

Dalgarno, Emily. Virginia Woolf and the Visible World. Cambridge: Cambridge UP, 2001. Print.

Davidson, Cathy N. and Jessamyn Hatcher, Eds. No More Separate Spheres! Durham: Duke UP, 2002. Print.

D’Cruze, Shani. "Women and the Family." Women's History Britain, 1850-1945: An Introduction. Ed. Jane Purvis. New York: St. Martin’s P, 1995. 51-84. Print.

de Gay, Jane. "Behind the Purple Triangle: Art and Iconography in To the Lighthouse." Woolf Studies Annual. 5 (1999): 1-23. Print.

DeKoven, Marianne. Rich and Strange: Gender, History, Modernism. Princeton: Princeton UP, 1991. Print.

De Man, Paul. "Hegel on the Sublime." Aesthetic Ideology. Ed. Andrzej Warminski. Minneapolis: U of Minnesota P, 1996. 105-118.

--------“Phenomenality and Materiality in Kant.” Aesthetic Ideology. Ed. Andrzej Warminski. Minneapolis: U of Minnesota P, 1996. 70-90.

Dever, Carolyn. Death and the Mother from Dickens to Freud: Victorian Fictions and the Anxiety of Origin. Cambridge: Cambridge UP, 1998.

Dix, Carol. D.H. Lawrence and Women. Totowa: Rowman and Littlefield, 1980. Print.

Doolittle, Megan. "Fatherhood, Religious Belief and the Protection of Children in NineteenthCentury English Families." Gender and Fatherhood in the Nineteenth Century. Eds. 
Trev Lynn Broughton and Helen Rogers. New York: Palgrave Macmillan, 2007. 31-42. Print.

Donaldson, George. “"Men in Love’ D.H. Lawrence, Rupert Birkin, and Gerald Crich.” D.H. Lawrence: Centenary Essays. Bristol: Bristol Classical P, 1986. 41-?. Print.

Edelman, Lee. No Future: Queer Theory and the Death Drive. Durham: Duke UP, 2004. Print. Edwards, Erin E. "Extremities of the Body: The Anoptic Corporeality of As I Lay Dying." MFS: Modern Fiction Studies. 55.4 (2009): 739-764. MLA International Bibliography. EBSCO. Web. 10 June 2011.

Elert, Kerstin. Portraits of Women in Selected Novels by Virginia Woolf and E.M. Forster. Umea: U of Umea P, 1979.

Eliot, T.S. "Hamlet." The Norton Anthology of Modern and Contemporary Poetry: Modern Poetry. $3^{\text {rd }}$ Ed. Eds. Jahan Ramazani, Richard Ellmann, and Robert O’Clair. Vol. 1. New York: W.W. Norton and Co, 2003. 947-949. Print.

Ellis, David. D.H. Lawrence: The Dying Game, 1922-1930: The Cambridge Biography of D.H. Lawrence. Cambridge: Cambridge UP, 2011. Print.

Ellis, Steve. Virginia Woolf and the Victorians. Cambridge: Cambridge UP, 2007. Print.

Eng, David L. The Feeling of Kinship: Queer Liberalism and the Racialization of Intimacy. Durham: Duke UP, 2010. Print.

Faulkner, William. As I Lay Dying. Faulkner: Novels 1930-1935. New York: The Library of America, 1985. 1-178.

Fernald, Anne E. Virginia Woolf: Feminism and the Reader. New York: Palgrave Macmillan, 2006. Print. 
Fernihough, Anne. D.H. Lawrence: Aesthetics and Ideology. New York: Oxford UP, 1993. Print.

Ferreira, Maria Aline. "'Glad Wombs' and 'Friendly Tombs': Reembodiments in D.H. Lawrence's Late Works." Writing the Body in D.H. Lawrence: Essays on Language, Representation, and Sexuality. Ed. Paul Poplawski. Westport: Greenwood P, 2001. 163175. Print.

Finkelstein, Bonnie Blumenthal. Forster's Women: Eternal Differences. New York: Columbia UP, 1974. Print.

Forbes, Shannon. “'When Sometimes She Imagined Herself Like Her Mother': The Contrasting Responses of Cam and Mrs. Ramsay to the Role of the Angel in the House." Studies in the Novel. 32.4 (2000): 464-487. Print.

Forster, E.M. Howards End. Ed. Alistair M. Duckworth. New York: Bedford Books, 1997. Print.

Fowler, Doreen. "Matricide and the Mother's Revenge: As I Lay Dying." The Faulkner Journal. 4.1-2 (1988): 113-125. Print.

Frank, Cathrine O. "Fictions of Justice: Testamentary Intention and the (Il)legitimate Heir in Trollope's Ralph the Heir and Forster's Howards End." ELT. 47.3 (2004): 311-330. Print.

Frattarola, Angela. "Developing an Ear for the Modernist Novel: Virginia Woolf, Dorothy Richardson, and James Joyce.” Journal of Modern Literature. 33.1 (2009): 132-153. Print.

Freccero, Carla. Queer/Early/Modern. Durham: Duke UP, 2005. Print. 
Friedman, Alan Warren. Fictional Death and Modernist Enterprise. Cambridge: Cambridge UP, 2008. Print.

Friedman, Susan Stanford. "Creativity and the Childbirth Metaphor." Feminist Studies. 13.1 (1987): 49-82. Print.

Freedman, Ariela. Death, Men, and Modernism: Trauma and Narrative in British Fiction from Hardy to Woolf. New York: Routledge, 2003. Print.

Freeman, Barbara Claire. The Feminine Sublime: Gender and Excess in Women's Fiction. Berkeley: U of California P, 1995.

Freud, Sigmund. "Femininity." Feud On Women: A Reader. Ed. Elisabeth Young-Bruehl. New York: W.W. Norton \& Co, 1992. 342-362. Print.

Froula, Christine. Modernism's Body: Sex, Culture, and Joyce. New York: Columbia UP, 1996.

----- Virginia Woolf and the Bloomsbury Avant-Garde: War, Civilization, Modernity. New York: Columbia UP, 2005. Print.

Fry, Roger. "The Artist and Psycho-Analysis." A Roger Fry Reader. Ed. Christopher Reed. Chicago: U of Chicago P, 1996. 351-365. Print.

Garrity, Jane. Step-Daughters of England: British Women Modernists and the National Imaginary. Manchester: Manchester UP, 2003. Print.

Gilbert, Sandra and Susan Gubar. No Man's Land: The Place of the Woman Writer in the Twentieth Century. Hartford: Yale UP, 1991.

Gwin, Minrose C. The Feminine and Faulkner: Reading (Beyond) Sexual Difference. Knoxville: U of Tennessee P, 1990. Print. 
Halberstam, Judith. In a Queer Time and Place: Transgender Bodies, Subcultural Lives. New York: New York UP, 2005. Print.

Hardin, Michael. “Freud's Family: The Journey to Bury the Death Drive in Faulkner's As I Lay Dying." Southern Studies. 5.3-4 (1994): 95-103. Print.

Harrison, Andrew. 'D.H. Lawrence's 'Perfervid Futuristic Style' and the Writing of the Body in The Rainbow." Writing the Body in D.H. Lawrence: Essays on Language, Representation, and Sexuality. Ed. Paul Poplawski. Westport: Greenwood P, 2001. 4554. Print.

Heilbrun, Carolyn G. Toward a Recognition of Androgyny. New York: W.W. Norton \& Co, 1993. Print.

Hewson, Marc. “'My children were of me alone': Maternal Influence in Faulkner's As I Lay Dying.” Mississippi Quarterly: The Journal of Southern Cultures. 53.4 (2000): 551-567. Print.

Higgins, Lesley. The Modernist Cult of Ugliness: Aesthetic and Gender Politics. New York: Palgrave Macmillan, 2002.

Higgins, Lesley, Laurel Brake, and Carolyn Williams. No Time for Pater: The Silenced Other of Masculinist Modernism. Greensboro: ELT, 2002.

Hirai, Masako. "Arguing with Ruskin: The Romantic Sublime and the Erotic Labour in The Rainbow." D.H. Lawrence and Literary Genres. Simonetta de Fillippis and Nick Ceramella, Eds. Napoli: Laffredo, 2004. 205-218. Print.

Hustis, Harriet. "Masculinity as/in Comic Performance in As I Lay Dying and The Sound and the Fury." The Faulkner Journal. 15.1-2 (1999): 107-123. Print. 
Irigaray, Luce. Speculum of the Other Woman. Trans. Gillian C. Gill. Ithaca: Cornell UP, 1985. Print.

Jalland, Pat. Death in the Victorian Family. New York: Oxford UP, 2000. Print.

Jeffreys, Sheila. "Women and Sexuality." Women's History Britain, 1850-1945: An Introduction. Ed. Jane Purvis. New York: St. Martin’s P, 1995. 193-216. Print.

Johnston, Georgia. The Formation of $20^{\text {th }}$-Century Queer Autobiography: Reading Vita Sackville-West, Virginia Woolf, Hilda Doolittle, and Gertrude Stein. New York: Palgrave Macmillan, 2007.

Joyce, Simon. The Victorians in the Rearview Mirror. Athens: Ohio UP, 2007.

Kant, Immanuel. Critique of Judgment. Trans. Werner S. Pluhar. Indianapolis: Hackett Publishing Company, 1987.

Kenner, Hugh. The Pound Era. Berkeley: U of California P, 1973. Print.

Kinkead-Weekes. D.H. Lawrence: Triumph to Exile 1912-1922: The Cambridge Biography of D.H. Lawrence. Cambridge: Cambridge UP, 1996. Print.

Knights, Ben. Writing Masculinities: Male Narratives in Twentieth Century Fiction. New York: St. Martin's P, Inc, 1999. Print.

Kristeva, Julia. Powers of Horror: An Essay on Abjection. New York: Columbia UP, 1982.

-----“Stabat Mater.” The Kristeva Reader. Ed. Toril Moi. New York: Wiley-Blackwell, 1991. 160-186. Print.

Krockel, Carl. D.H. Lawrence and Germany: The Politics of Influence. Amsterdam-New York: Rodopi, 2007. Print. 
Krouse, Tonya. "'I Would Rather Be a Cyborg Than A Goddess': Lily Briscoe, Mrs. Ramsay, and the Postmodern Sublime." Virginia Woolf and Her Influences: Selected Papers from the Seventh Annual Conference on Virginia Woolf. New York, NY: Pace UP, 1998. 294-301. Print.

Lacan, Jacques. "God the Jouissance of the Woman." Feminine Sexuality: Jacques Lacan and the ecole freudienne. Eds. Juliet Mitchell and Jacqueline Rose. New York: W.W. Norton \& Co, 1985. Print.

---- "The Signification of the Phallus." Ecrits: The First Complete English Edition. Trans. Bruce Fink. New York: W.W. Norton \& Co, 2007. 575-584.

Ladd, Barbara. Resisting History: Gender, Modernity, and Authorship in William Faulkner, Zora Neale Hurston, and Eudora Welty. Baton Rouge: Louisiana State UP, 2007. Print.

Laity, Cassandra. Ed. Gender, Desire, and Sexuality in T.S. Eliot. Cambridge: Cambridge UP, 2004.

Laqueur, Thomas. Making Sex: The Body and Gender from the Greeks to Freud. Cambridge: Harvard UP, 1992. Print.

Lawrence, D.H. "Books." Reflections on the Death of a Porcupine and Other Essays. Ed. Michael Herbert. Cambridge: Cambridge UP, 1988. 197-200. Print.

-----"Fantasia of the Unconscious." 1922. Psychoanalysis and the Unconscious and Fantasia of the Unconscious. Mineola: Dover, 2005. 53-225. Print.

-----Lady Chatterley's Lover. 1928. New York: Penguin Books, 1994. Print.

-----“On Taking the Next Step.” Reflections on the Death of a Porcupine and Other Essays. Ed. Michael Herbert. Cambridge: Cambridge UP, 1988. 387-388. Print. 
-----"Psychoanalysis and the Unconscious." 1921. Psychoanalysis and the Unconscious and Fantasia of the Unconscious. Mineola: Dover, 2005. 1-49. Print.

-----The Rainbow. Cambridge Lawrence ed. New York: Penguin Classics, 2007. Print.

Lee, Hermione. Virginia Woolf. New York: Vintage, 1999. Print.

Lehr, Valerie. Queer Family Values: Debunking the Myth of the Nuclear Family. Philadelphia: Temple UP, 1999. Print.

Leja, Michael. Looking Askance: Skepticism and American Art from Eakins to Duchamp. Berkeley: U of California P, 2007.

Lewiecki-Wilson, Cynthia. Writing Against the Family: Gender in Lawrence and Joyce. Carbondale: Southern Illinois UP, 1994. Print.

Lilienfeld, Jane. “The Deceptiveness of Beauty': Mother Love and Mother Hate in To the Lighthouse." Twentieth Century Literature. 23.3 (1977): 345-376. Print.

----“"To Have the Reader Work with the Author': The Circulation of Knowledge in Virginia Woolf's To the Lighthouse and Toni Morrison's Jazz." Modern Fiction Studies. 52.1 (2006): 42-65. Print.

Lokki, Kari Elise. “Orlando and Incandescence: Virginia Woolf’s Comic Sublime.” Modern Fiction Studies. 38.1 (1992): 235-252. Print.

Love, Heather K. "Forced Exile: Walter Pater's Queer Modernism." Bad Modernisms. Ed. Douglas Mao and Rebecca Walkowitz. Durham, Duke UP, 2006. 19-43. Print.

Marcus, Jane. Virginia Woolf and the Languages of Patriarchy. Bloomington: Indiana UP, 1987. Print. 
Marshall, Denise. "Slaying the Angel and the Patriarch: The Grinning Woolf." Women's Studies. 15 (1988): 149-177. Print.

Martin, Robert K. “'It Must Have Been the Umbrella': Forster's Queer Begetting.” Queer Forster. Eds. Robert K. Martin and George Piggford. Chicago: U of Chicago P, 1997. 255-273. Print.

Martin, Robert K, and George Piggford. Eds. Queer Forster. Chicago: U of Chicago P, 1997. Print.

Mazzoni, Cristina. Maternal Impressions: Pregnancy and Childbirth in Literature and Theory. Ithaca: Cornell UP, 2002. Print.

McCormack, Matthew. “Married Men and the Fathers of Families': Fatherhood and Franchise Reform in Britain." Gender and Fatherhood in the Nineteenth Century. Eds. Trev Lynn Broughton and Helen Rogers. New York: Palgrave Macmillan, 2007. 43-54. Print.

McKeon, Michael. The Origins of the English Novel, 1600-1740. Baltimore: Johns Hopkins UP, 2002. Print.

Mellor, Anne K. Romanticism and Gender. New York: Routledge, 1992. Print.

Middleton, Peter. The Inward Gaze: Masculinity and Subjectivity in Modern Culture. New York: Routledge, 1992. Print.

Millet, Kate. Sexual Politics. Garden City: Doubleday and Co, 1970. Print.

Minow-Pinkney, Makiko. Virginia Woolf and the Problem of the Subject: Feminine Writing in the Major Novels. Reprint Ed. Edinburgh: Edinburgh UP, 2011. Print.

Monaco, Beatrice. Machinic Modernism: The Deleuzian Literary Machines of Woolf, Lawrence and Joyce. New York: Palgrave Macmillan, 2008. Print. 
Mozejko, Edward. "Tracing the Modernist Paradigm: Terminologies of Modernism." Modernism. Ed. Astradur Eysteinsson and Vivian Liska. Vol. 1. Philadelphia: John Benjamins Publishing Company, 2007. 11-33.

Nielsen, Paul S. "What Does Addie Bundren Mean, and How Does She Mean It?" The Southern Literary Journal. 25.1 (1992): 33-39. Print.

Olson, Jeane N. “E.M. Forster's Prophetic Vision of the Modern Family in Howards End." Texas Studies in Literature and Language. 35.3 (1993): 347-362. Print.

Pound, Ezra. "Hugh Selwyn Mauberley." The Norton Anthology of Modern and Contemporary Poetry: Modern Poetry. $3^{\text {rd }}$ Ed. Eds. Jahan Ramazani, Richard Ellmann, and Robert O’Clair. Vol. 1. New York: W.W. Norton and Co, 2003. 354-366. Print.

Psomiades, Kathy Alexis. Beauty's Body: Femininity and Representation in British Aestheticism. Paolo Alto: Stanford UP, 1997. Print.

Puchner, Martin. "The Aftershocks of Blast: Manifestos, Satire, and the Rear-Guard of Modernism.” Bad Modernisms. Eds. Douglas Mao and Rebecca L. Walkowitz. Durham: Duke UP, 2006. 44-67. Print.

Purvis, Jane. Ed. Women's History Britain, 1850-1945: An Introduction. New York: St. Martin's P, 1995. Print.

Rado, Lisa. The Modern Androgyne Imagination: A Failed Sublime. Charlottesville: U of Virginia P, 2000. Print.

Rose, Phyllis. Woman of Letters: The Life of Virginia Woolf. New York: Harcourt, 1987. Print. Rosenman, Ellen Bayuk. The Invisible Presence: Virginia Woolf and the Mother-Daughter Relationship. Baton Rouge: Louisiana State UP, 1986. Print. 
Rowbotham, Sheila. A Century of Women: The History of Women in Britain and the United States. New York: Viking, 1997. Print.

Rubenstein, Roberta. “'I meant nothing by The Lighthouse’: Virginia Woolf”s Poetics of Negation.” Journal of Modern Literature. 31.4 (2008):36-53. Print.

Ruddick, Sara. "Learning to Live with the Angel in the House." Women's Studies. 4 (1977): 185. Print.

Ruderman, Judith. D.H. Lawrence and the Devouring Mother: The Search for a Patriarchal Ideal of Leadership. Durham: Duke UP, 1984.

Sass, Karen R. "At a Loss for Words: Addie and Language in As I Lay Dying." The Faulkner Journal. 6.2 (1991): 9-21. Print.

Scarry, Elaine. The Body in Pain: The Making and Unmaking of the World. New York: Oxford UP, 1985. Print.

Seelow, David. Radical Modernism and Sexuality: Freud/Reich/D.H. Lawrence and Beyond. New York: Palgrave Macmillan, 2005. Print.

Showalter, Elaine. Sexual Anarchy: Gender and Culture at the Fin de Siècle. New York: Virago P Ltd, 1992. Print.

Siegel, Carol. Lawrence Among the Women: Wavering Boundaries in Women's Literary Traditions. Charlottesville: U of Virginia P, 1991. Print.

Simpson, Hilary. D.H. Lawrence and Feminism. DeKalb: Northern Illinois UP, 1982. Print.

Slankard, Tamara. “'No Such Thing as Was': The Fetishized Corpse, Modernism, and As I Lay Dying." Faulkner Journal. 24.2 (2009): 7-28. Print. 
Sprengnether, Madelon, Claire Kahane, and Shirley Nelson Garner. Eds. The (M)other Tongue: Essays in Feminist Analytic Interpretation. Ithaca: Cornell UP, 1985. Print.

Steinberg, Erwin R. "D.H. Lawrence: Mythographer.” Journal of Modern Literature. 25.1 (2001): 91-108. Print.

Surette, Leon. The Birth of Modernism: Ezra Pound, T.S. Eliot, W.B. Yeats, and the Occult. Montreal: McGill-Queen's UP, 1994. Print.

Tobin, Vera. "Joint Attention, To the Lighthouse, and Modernist Representations of Intersubjectivity." English Text Construction. 3.2 (2010): 185-202. Print.

Warner, Michael. The Trouble with Normal: Sex, Politics, and the Ethics of Queer Life. Cambridge: Harvard UP, 1999. Print.

Watt, Ian. The Rise of the Novel: Studies in DeFoe, Richardson, and Fielding. Whitefish: Kessinger Publishing, 2010. Print.

Wexler, Joyce Piell. Who Paid for Postmodernism?: Art, Money, and the Fiction of Conrad, Joyce, and Lawrence. Fayetteville: U of Arkansas P, 1997. Print.

White, Leslie. "Vital Disconnection at Howards End." Twentieth-Century Literature. 51.1 (2005): 43-63. Print.

Williams, Linda Ruth. Sex in the Head: Visions of Femininity and Film in D.H. Lawrence. Detroit: Wayne State UP, 1993. Print.

Wood, Amy Louise. "Feminine Rebellion and Mimicry in Faulkner's As I Lay Dying." The Faulkner Journal. 9.1-2 (1993): 99-112. Print.

Woolf, Virginia. A Room of One's Own. 1929. New York: Harcourt, 1989. Print. 
-----"Professions for Women." Women and Writing: Remarkable Pieces on the Writing Life of Women. Ed. Michele Barrett. New York: Harcourt, 1979. 57-63. Print.

-----“A Sketch of the Past.” Moments of Being: A Collection of Autobiographical Writing. $2^{\text {nd }}$ Ed. Ed. Jeanne Schulkind. New York: Harcourt, 1985. 61-159. Print.

------To the Lighthouse. Ed. Mark Hussey. New York: Harvest Books, 2005. Print.

Worthen, John. D.H. Lawrence: The Early Years, 1885-1912: The Cambridge Biography of D.H. Lawrence. Cambridge: Cambridge UP, 1992. Print.

-----D.H. Lawrence: The Life of an Outsider. New York: Counterpoint, 2005. Print.

Yaeger, Patricia. “The 'Language of Blood': Toward a Maternal Sublime.” Genre. 25 (1992): 524.

Zima, Peter V. "The Subject the Beautiful and the Sublime: Adorno and Lyotard between Modernism and Postmodernism.” Modernism. Eds. Astradur Eysteinsson and Vivian Liska. Vol. 1. Philadelphia: John Benjamins Publishing Company, 2007. 143-153.

Žižek, Slavoj. The Sublime Object of Ideology. Brooklyn: Verso, 1989.

Zylinska, Joanna. On Spiders, Cyborgs, and Being Scared: The Feminine and the Sublime. Manchester: Manchester UP, 2001.

Zytaruk, George J. “The Doctrine of Individuality: D.H. Lawrence's 'Metaphysic.” D.H. Lawrence: A Centenary Consideration. Eds. Peter Balbert and Phillip L. Marcus. Ithaca: Cornell UP, 1985. 237-253. Print. 